Terence Dooley

\title{
The mortgage papers of St Patrick's College, Maynooth, I87I-1923
}

\section{Introduction}

On 1 January 1871, under the terms of the Irish Church act of $1869,{ }^{2}$ St Patrick's College, Maynooth, received a capital sum of $£ 369$,040 in compensation for the withdrawal of the annual parliamentary grant of $£ 26,360$ that had been set under the Maynooth act of $1845 \cdot{ }^{3}$ Much to the delight of the then president, Rev C. W. Russell, ${ }^{4}$ the trustees would 'no longer [be] subject to official control, nor liable to be made the occasion of unseemly exhibitions in Parliament' but would have the power to independently administer the entire property, 'subject to one sole condition, the equitable one of applying the proceeds [of endowment] to the proper purposes of the trust'.5 In other words, the capital sum invested would have to provide an annual return comparable (at least) to the previous annual grant in order to safeguard the financial running of the college, of which the trustees, the only legally constituted religious corporation in Ireland, were now the legal proprietors. ${ }^{6}$

Back in October 1870, the trustees had already resolved that the bulk of the lump sum should be invested in 3 per cent stock or consols 'unless a better and equally secure investment should be available'. ${ }^{7}$ But then followed a period of uncertainty when the trustees became concerned about possible legislative restrictions that they might be subject to in regard to how and where they invested the lump sum. After prolonged investigation by their legal representatives, it was ascertained that the trustees were not legally obliged to invest in government stock or bank stock of the Bank of England or the Bank of Ireland. This was deemed fortunate, as India stock and real securities in any part of Britain or Ireland seemed a more enticing option. ${ }^{8}$ Thus, after the money was received in March 1871 , almost $£ 150,000$ was invested in India 4 per cent and

\footnotetext{
I I would like to thank Monsignor P. J. Corish for allowing me to quote from this archive. Thanks also to Ms Penny Woods, Ms Celia Kehoe and Mr Paul Hoary for being so patient and cooperative during all my visits to the Russell Library of St Patrick's College, Maynooth. 232 \& 33 Vict. c.42. 3 The lump sum also included an additional $£ 3,236$ in interest added because of the delay in payment; P. J. Corish, Maynooth College 1795-1995 (Dublin, 1995), p. 29; see also John Healy, Maynooth College, 1795-1895 (Dublin, c. 1899). 4 Charles W. Russell (1812-80) was born in County Down. He entered Maynooth in 1826 and was ordained in 1835 . He became president of the college in 1857 , having served as professor of Ecclesiastical History since 1845 . He was a prolific writer, a trustee of the National Library, a founding member of the Historical Manuscripts Commission but, P. J. Corish points out, is 'best remembered for his role in the conversion of John Henry Newman'; Corish, Maynooth College, p. 483. 5 Report of the president [of St Patrick's College] 1875-76, p. 12. 6 Ibid.; Corish, Maynooth College, p. 179. 7 Trustees journal, 19 Oct. 1870 (MCA, B2/1/1). 8 Financial report for the year ended 31 March 1874 , p. 7.
} 
5 per cent stocks, and $£_{116,000}$ in a variety of other 3 per cent stock. However, the bursar's report for 1871-72 suggested that investment in India stock was of a 'temporary character' and that in the near future the trustees would have to consider their conversion into other securities. The finance committee agreed that India stock suited only the immediate exigencies of the college: annual dividends were very favourable, but the fact that the stock would only be redeemable at par (at best) in 1880 suggested to them that they needed to be sold before the period of redemption so as to avoid 'running the risk of loss from the depreciation of value'. 9

There was one other enticing investment avenue to be explored - mortgage loans to Irish landlords. From about 1853 , as the Irish economy developed and the spectre of the Great Famine diminished, landlords had borrowed extravagantly. Irish land had once again become safe collateral: many tenant farmers were prospering as a result of the rise in agricultural prices, they were paying their rents in full and on time, and - except during a temporary downturn in the early 1860 s - lending institutions and private financiers were confident that the good times were going to continue long into the future. ${ }^{10}$ It was not long, therefore, before the trustees began to contemplate the financial advantages of lending money to Irish landlords. In April 1871, the trustees offered almost $£ 91,600$ at 4.25 per cent to George Arthur Hastings, the seventh earl of Granard of Newtownforbes in County Longford." (A second loan of $£ 2,200$ was given to Granard to pay the legal costs of acquiring the first loan.) There are a number of possible reasons why the trustees perceived Granard to be an ideal candidate: he was a Roman Catholic, which was in itself unusual amongst the Irish aristocracy; he possessed the necessary élitist social credentials; he was a knight of the Order of Malta; and he had built up a close relationship with many of the leading ecclesiastics of his time. The finance committee was delighted with this transfer of investments from stocks to land:

Such advantageous opportunities for investment on land rarely occur and fortunately furnish us with the means of disposing of all our India stock at a profit of $£ 3,160$ on cost of purchase ... the security tendered is above all

\footnotetext{
9 Bursar's financial statement for year ended 31 Mar. 1872 (MCA, B3/10/2). Io For a more detailed discussion, see Terence Dooley, The decline of the big house in Ireland: a study of Irish landed families 18601960 (Dublin, 2001), pp. 79-111; see also L. P. Curtis jr., 'Encumbered wealth: landlord indebtedness in postFamine Ireland' in American Historical Review, lxxxv, 2, (April, 1980), pp 332-67; W. E. Vaughan, 'An assessment of the economic performance of Irish landlords, $1851-81$ ' in F. S. L. Lyons and R. A. J. Hawkins (eds), Ireland under the Union: varieties of tension (Oxford, 1980), pp 173-99; James S. Donnelly jr., The land and people of nineteenth century Cork: the rural economy and the land question (London, 1975). II George Arthur Hastings, seventh Earl of Granard $(1833-89)$ K. P. succeeded to the family title and estates as a minor on the death of his grandfather, George, in 1837 . His own father had died in 1836 . He was knighted by the Order of Malta, a vice-administrator of Connaught, an officer of the gth Battalion of the Rifle Brigade and a member of the senate of the Royal University of Ireland. He married firstly Jane, daughter and coheiress of Hamilton Morgan of Johnstown Castle in County Wexford. They had two daughters before his wife died prematurely. He married secondly, the Hon. Frances Mary Petre, eldest daughter of the 12th Baron Petre and they had six sons and two daughters. He died on 25 August 1889. His wife lived until 1920; Burke's peerage and baronetage (105th ed., London, 1970), pp 1153-4.
} 
exception and the annual increase of the college revenues consequent on this operation would be considerable. ${ }^{12}$

The conclusion of the committee reflected the prevailing optimism in land values - the security was 'above all exception'. In the long term, it was to be an optimism that was severely misplaced, but in the meantime, the success of the existing mortgages favourably impressed the trustees as the preferable (and potentially most profitable) form of investment for the future. By 1875 , all of the India stock and over half of the 3 per cent stock had been sold, realising $£ 200,500$, of which $£ 183,100$ was re-invested in mortgage loans. This now brought the total investment in the same to almost $£ 274,000$ (Table 1 ). ${ }^{13}$ In October 1873 Blayney Townley Balfour ${ }^{14}$ of Townley Hall in Louth had received $£_{25}$,000; in December 1873 Myles William O'Reilly ${ }^{15}$ of Knockabbey, also in Louth, had received $£ 6,000$; in February 1874 Alexander John Robert Stewart ${ }^{16}$ and his eldest son, Alexander George John Stewart, of Ards in Donegal (and Portglenone in Antrim) had received $£ 55,000$; in June 1874 Valentine Lawless, Lord Cloncurry ${ }^{17}$ of Lyons in Kildare, had received $£ 45,000$, followed by two further loans of $£ 25,000$ each. ${ }^{18}$

Mortgage loans, according to the college president, Rev C. W. Russell, were 'chiefly for the purpose of transferring a portion of the college capital from a less profitable to a more profitable investment'. ${ }^{19}$ By 1874 the college was receiving $£ 11,720$ in income from interest on these loans and just over $£ 2,700$ from stocks. ${ }^{20}$ The trustees, while realising the necessity of wise investment in order to keep the college running, were also keen to provide free places or scholarships to less well-off candidates for the priesthood. Thus, in 1875 the president pointed out that the re-investment of $£ 40,000$ government 3 per cent stock in mortgage loans at 4.25 per cent to Lord Cloncurry had represented 'a favourable opportunity of effecting this desirable result'. ${ }^{21}$

12 Financial report for the year ended 31 Mar. 1872, p. 6. I3 Report of the president, 1875-76, pp. 30-31. 14 Blayney Balfour was born in 1799 and succeeded to the family estate at Knockabbey in County Louth in 1856. In total he owned around 7,000 acres, primarily situated in Louth and Meath, with lands also in Westmeath, Armagh, Tyrone and Down. He had been educated at Harrow and Oxford and was a former governor of the Bahamas; John Bateman, The great landowners of Great Britain and Ireland (4th ed., London, 1883), p. 23. I5 Myles William O'Reilly (1825-80) was described as having descended from a branch 'of the ancient Milesian house of O'Reilly, princes of east Bryfny'. O'Reilly was invited to Rome in the late 1850 os by Pope Pius IX where he took command of the Irish Brigade in the pontifical service. He left Rome in 1862 and on his return home he was elected as MP for Longford. He is described by P. J. Corish as one of a number of Liberal M.P.s who were 'well disposed' to St Patrick's College; Burke's dictionary of the landed gentry of Great Britain and Ireland (London, 1858 ed.), p. 889; Sidney Lee (ed.), Dictionary of national biography, vol. xlii (London, 1895), p. 200; Corish, Maynooth College, p. 176.16 Address given as Portglenone in County Antrim, although he is most associated with Ards, Letterkenny, County Donegal. Born in 1827, Stewart inherited the family estate of over 44,000 acres in 1851; Bateman, Great landowners, p. 423. I7 Born 1840, Valentine Lawless inherited the Cloncurry title and estate in 1869 . He had been educated at Eton. He became renowned as an agriculturist and an improving landlord, one of those who, in the post-Famine period, played an active role in the day-to-day management of his estate. He died in 1928; Bateman, The great landowners, p. 97; Dooley, Decline of the big house, p. 36.18 See document 1 below. 19 Report of the president, 1875-76, p. 32. 20 Financial report for year ended 31 Mar. 1874, p. 11. 2I Ibid., p. 10. 
MORTGAGE PAPERS OF ST PATRICK'S COLLEGE, MAYNOOTH, I87I-I923

Table 1: Mortgage loans offered by the trustees of Maynooth College, 1871-4

\begin{tabular}{lccc}
\hline \multicolumn{1}{l}{ Mortgagee } & Amount $(£)$ & Interest rate (\%) & Annual interest $(£)$ \\
\hline 1 Earl of Granard, & 92,592 & 4.25 & $3,935.3 .8$ \\
Castleforbes, & & & \\
$\begin{array}{l}\text { Co. Longford } \\
\text { Townley Balfour, }\end{array}$ & 25,000 & 4.25 & $1,062.10 .6$ \\
$\begin{array}{l}\text { Townley Hall, } \\
\text { Co. Louth }\end{array}$ & & & \\
3 Myles O'Reilly, & 6,000 & 4.75 & 285 \\
$\begin{array}{l}\text { Knockabbey, } \\
\text { Co. Louth }\end{array}$ & & & \\
$4 \begin{array}{l}\text { A. J. R. Stewart, } \\
\text { Portglenone, }\end{array}$ & 55,000 & 4.25 & $2,337.10 .0$ \\
$\begin{array}{l}\text { Co. Antrim } \\
\text { Lord Cloncurry, }\end{array}$ & 45,000 & 4.25 & $1,912.10 .0$ \\
$\begin{array}{l}\text { Lyons, } \\
\text { Co. Kildare }\end{array}$ & & & $1,062.10 .0$ \\
6 Lord Cloncurry & 25,000 & 4.25 & $1,125.6 .0$ \\
7 Lord Cloncurry & 25,000 & 4.25 & $1,720.3 .8$ \\
\hline
\end{tabular}

Source: Financial report for year ended 31 Mar. 1874, p. 11.

The terms of the loans were generally much the same. Most were taken out over a period of up to twenty years at 4.25 to 4.75 per cent interest, if punctually paid; if not punctually paid, a penal interest rate of 5 per cent was imposed. The principal remained the same over the loan period, the stipulation being that it would be paid off on the agreed date after the twenty years had elapsed. (Alternatively, the loan could be renewed for a further period.) ${ }^{22}$ In November 1879 , Cloncurry wrote to the trustees: 'Gentlemen, I hereby give you notice that I will on the 28 th day of November 1880 repay to you the principal sum of $£ 25,000$ secured by mortgage dated the 19th day of June 1874 on the lands of Ballyvoneen and others in the Baronies of Skeathy and Oughterany in the County of Kildare.'23 And in the following month, he made his future intentions more clear when he wrote to Fr Thomas Farrelly, ${ }^{24}$ the college bursar:

\section{Dear Sir,}

My solicitor has given notice 'pro forma' to Mr Carraher [the college's solicitor] of my intention to pay off the loan of $£ 25,000$ which I borrowed from the trustees of your college at $4^{\mathrm{T}} / 2$ per cent upon certain lands in the barony

22 Note appended to rental of Townley Hall estate, n.d. (MCA, 107/5). 23 Lord Cloncurry to trustees of Maynooth College, November 1879 (MCA, 112/4). 24 Thomas Farrelly (1814-90) was born in County Meath and entered Maynooth in 1837 . In 1843 he became assistant bursar and then bursar in 1845 . He retired in 1881; Corish, Maynooth College, p. 455. 


\section{ARCHIVIUM HIBERNICUM}

of Skeathy in Co. Kildare. I therefore write to tell you that I have no wish to break off the financial arrangements which have been satisfactory to me and which I hope have been equally so to your trustees, but it will be necessary for me to make an alteration in one of the loans and its security.

The first loan of $£ 70,000^{25}$ at $4^{\mathrm{T}} / 4$ per cent was made for ten years certain, \& I have no wish to alter it, but you may remember that at the time when the second loan of $£ 25,000$ at $4^{1 / 2}$ per cent was being negotiated I mentioned to you that I could only make it for five years, because a great alteration would take place within that time in the circumstances of the lands included in that mortgage.

The rental is now nearly three times the amount then stated (owing to the fall of old leases) and I hope to borrow a much larger sum upon the security of those lands. If your trustees have other sums ready to invest I would be glad to enter into negotiations with them for a larger loan, or I would borrow the $£ 25,000$ as a new loan secured upon certain townlands leaving me free to deal with the remainder of the lands as security for another loan elsewhere.

In any case I will not enter into any negotiations for a loan elsewhere without first knowing the views of your trustees upon the subject. The notice recently given will not terminate for twelve months yet to come, but there is nothing to prevent an earlier arrangement if mutually agreed upon.

Faithfully yours,

Cloncurry.

All the mortgages were due to be redeemed between 1879 and $1892 .{ }^{26}$ Ironically, the period between those very years proved to be cataclysmic in terms of a deterioration in landlord-tenant relations and a consequential increase in landlord indebtedness and tenant hardship caused by a prolonged agricultural depression, which gave rise to the Land League (1879-82); the later establishment of the National League (formed in October 1882); the Land War of 1879-82; the adoption of the Plan of Campaign on over two hundred estates from 1885 to 1891 (or beyond in some cases); widespread rent strikes; a significant increase in evictions and a general rise in agrarian crime.

The story of the relationship between the trustees of the college and its mortgagors as preserved in the substantial archive generated during these years, and now deposited in the Russell Library, St Patrick's College, Maynooth, is a fascinating and revealing one. It is a story inextricably entwined with the socioeconomic and political developments of the late nineteenth and early twentieth

25 This was actually two separate loans of $£ 45,000$ and $£ 25,000$. See table above. 26 Several other applications for loans were made in the early 1870 s but were rejected by the finance committee as they did not come 'strictly within the class of securities suitable' to the trustees or else applicants were 'requiring an amount disproportionate to the value of the property'; Financial report for the year ended 31 Mar. 1872, p. 5. 
centuries. ${ }^{27}$ It provides a remarkable, indeed unique, insight into the declining financial circumstances of Irish landlords, as well as into the precarious position of tenant farmers, who, finding themselves between the rock and the hard place of rental payments or economic survival, organised themselves into agrarian movements that eventually forced the hands of both landlords and mortgagees.

While estate papers can often reveal the plight of Irish landlords during the late Victorian period, the mortgage papers are one of the few collections that reveal much about the tenants, particularly those on the Granard estates in Longford and Leitrim. This is important, for they provide a necessary balance to estate papers and to other sources generated by the establishment. The lengthy Report of the Clerical Commission (see document 62 below), appointed in the early 1890 os to confer with tenants of the unsold residue of the Granard estate, is significant in this respect. ${ }^{28} \mathrm{~A}$ close analysis of this document highlights the levels of congestion on the estate and suggests the potential long-term consequences that the achievement of tenant proprietorship alone could not and would not solve. The failure of the land acts up to independence to address the problem of uneconomic holdings was a major contributory factor to the outbreak of the so-called 'ranch war' of the early twentieth century and again in the last significant phase of land agitation from 1917 to 1923 . After the passing of the 1923 Land Act, ${ }^{29}$ land policy in independent Ireland was very much dictated by the relief of the type of congestion that existed around Drumlish and Castleforbes.

As well as informing on tenurial arrangements, government valuation and rent levels, the Maynooth mortgage papers, taken as a whole, contain a wealth of unwitting testimony: nuggets that illuminate such matters as the importance of American remittances to the local economy; the role of 'the great fair of Longford' in the local economy; the payment of annual rents; and the existence of a thriving spool factory in Sligo in the late 1880 os that purchased most of the timber sold from the Granard estate. ${ }^{30}$ Just as significantly, they throw light on an aspect of Catholic Church history not often considered - the financial running of the national seminary after the passing of the Irish Church Act. They provide an insight into some of the underlying tensions that existed between members of the Catholic hierarchy and, indeed, the awkward position in which the trustees found themselves when faced with a situation whereby parish clergy were encouraging and organising their predominantly Catholic and Nationalist congregations to defy landlords and withhold rental payments, which in turn impacted upon the latter's ability to meet their financial obligations to the trustees, thereby threatening the college's very existence.

27 The story has been partly revealed by this author elsewhere, including the relationship of the trustees with the earl of Granard in Terence Dooley, 'Landlords and mortgagees in late nineteenth-century Ireland: the case of Lord Granard and the trustees of Maynooth College, 1871-89' in Journal of the County Kildare Archaeological Society, 1998-99, vol. xviii (part iv), pp. 612-26. 28 See document 68. 29 1923/42 [I.F.S.] (5 Aug. 1923). 30 See, for example, document 32. 
It is the correspondence between the earl of Granard, his legal representatives and the college trustees and their legal representatives that is most enlightening and most voluminous. It is for that reason that this correspondence forms the main focus of this article. However, it would be unwise to conclude that all of the most interesting and the most informative of the documents generated by both sides are reproduced below. Only a representative selection is presented here, which, when arranged in a chronological order, allows the story of the relationship between the college trustees and the Granard estate to unfold. Because of pressure of space, many illuminating and important documents, such as schedules of deeds, could not be reproduced here.

While the Granard correspondence is the most voluminous and illuminating, there are, of course, many other revealing documents in the mortgage archive relating to the other estates. They emphasise that each of the mortgagors was affected in varying degrees, at one time or another, by the socio-political events and economic trends from the late 1870 . Thus, what follows in this introduction is a brief narrative drawing upon these documents in order to provide a framework that will help to contextualise the Granard documents. Where appropriate, some of these documents have also been reproduced in full, in keeping with the spirit of Archivium Hibernicum. ${ }^{31}$

\section{Landlord borrowing in post-Famine Ireland}

From the mid-1850s, when the Irish economy began to recover from the effects of the Great Famine, Irish Landlords borrowed extensively to consolidate inherited debts in one loan, to pay family charges, to finance the remodelling or embellishment of their existing houses and demesnes and, sometimes, simply to maintain a luxurious lifestyle..$^{32}$ Between 1862 and 1871 A. J. R Stewart of Portglenone, for example, had acquired six loans: three from the Scottish National Insurance Co. and three from the Standard Life Assurance Co. Four of these were acquired between 1862 and 1864 suggesting perhaps that when the economy suffered a temporary downturn during these years, and rents were once again difficult to collect, he went in search of loans to get him over the bad times. In February 1874 , he secured a mortgage loan from Maynooth and a month later, when drawing it down, he instructed the trustees as follows:

\section{Gentlemen,}

I request you to lodge the $£ 55,000$ for which this day I have executed a mortgage of my estates to you in the joint names of Mr Edward Carraher and Mr Robert Lyle [Stewart's solicitor] to be disposed of by them thus:

1stly. To pay your solicitor's charges and expenses per agreement for the loan of above sum dated the 2nd day of August 1873 and the differential

3 In the transcription of all documents contained herein, I have generally adopted the Irish Historical Studies rules pertaining to documents later in date than the eighteenth century. However, I have tended not to correct spelling mistakes in the original, preferring to use sic instead. 32 Dooley, The decline of the big house, pp. 18-43. 
interest from the 1st January last to the 1oth March inst[ant]. On said sum of $£ 55,000$

2ndly. To pay $£^{20,000}$ to the Scottish National Insurance Company and $£ 15,000$ to the Standard Assurance Company and the interest due on such sums and such bank commission as may be required for the immediate payment of the foregoing sums in Edinburgh.

3 rdly. To pay the balance of the above sum of $£ 55,000$ to Mr Robert Lyle for my account. 33

In drawing up the arrangements for the loans, there was a certain degree of naivety at best and carelessness at worst on behalf of the trustees and their legal representatives. Arguably, searches regarding the levels of indebtedness on individual estates were not thorough or comprehensive enough; there is, in fact, little evidence to suggest that they were carried out at all for the earlier loans. Some mortgagors were allowed to retain certain deeds that subsequently facilitated them in raising loans elsewhere, a temptation that was much too great for some to resist as the economic climate waned in the 1880 os. For the trustees the raising of subsequent loans became highly problematic, particularly when puisne mortgagees received priority over them. ${ }^{34}$ In September 1889 , P. A. Chance, the new college solicitor, wrote to Fr Walter Lee, parish priest of Bray and secretary to the board of trustees:

Dear Dean Lee,

Some months ago, Mr F. Browne solicitor Dawson Street, acting for $\mathrm{Mr}$ Stewart of Ards [and Portglenone] wrote requesting me to produce some deeds in court. The deeds required were executed by Mr Stewart - one of them was a deed of settlement, dated 1oth June 1873; the other a deed dated 27 th February 1874 , modifying the settlement. On searching amongst the papers at the bank, I found that the latter deed, which was executed just before the mortgage to the trustees, was not in the box at the bank. I understand that it has been permitted to remain in Mr Stewart's hands. I am bound to advise the trustees that this document directly affects the title to the lands subject to the mortgage, and that its absence might prove a great inconvenience. I should add that if money were obtained by a pledge of that deed, a serious question as to the priority of the trustees' charge might arise. I should add that Mr Stewart's solicitor alleges that $\mathrm{Mr}$ Carraher permitted him to retain the deed but no evidence of this is forthcoming.

Yours Truly,

P. A. Chance.

33 A. J. R. Stewart to the trustees of Maynooth College, 9 Mar. 1874 (MCA, 107/8); The balance came to $£_{19,700 .} 34$ In the case of Granard, see document $G_{2}$ below. 
The level of correspondence between mortgagors and trustees for the early to mid-1870s is unremarkable, composed mainly of receipts of payments and taxes, reflecting the stability of the Irish economy and the relative ease that the individual landlords had in meeting their financial obligations to the college. But, of course, the prolonged economic boom that had given rise to a great deal of optimism amongst landlords that the full and punctual payment of agricultural rents would in the future continue to sustain the repayment of debts and charges was undone by the onset of agricultural depression from 1877. From 1879, the mass organisation of tenant farmers under the Irish National Land League gave rise to widespread rent strikes throughout the country. In many instances, landlords found their tenants in opposition and they themselves castigated from public platforms, often regardless of whether or not they had been paternalistic or benevolent in the past. From early 1881 , the Granard estate became 'noted for its disturbed state'. ${ }^{35}$ The earl refused to grant the requested reductions from his tenants, who were efficiently organised by the parish priest of Drumlish, Fr Thomas Conefrey, who headed the local Land League. In January the earl threatened to evict 100 tenants and in reaction 'thousands' gathered outside his demesne, driving back his process servers and forcing his agent to admit that it would be impossible to make any practical use of any decrees that may be obtained until things settle down' ${ }^{36}$ In the short term this phase of the 'land war in Drumlish' was regarded by Granard's representatives as being nothing more than a pyrrhic victory for the tenants: large scale evictions were carried out a short time later. ${ }^{37}$ However, in the long term, the tenants arguably won the war. Through prolonged agitation they eventually forced Granard to sell the bulk of his estate to the occupying tenants, this 'victory' was long to be celebrated in local tradition, song and story, even giving rise to a centenary commemorative booklet in $1981 . .^{8}$

Others of the mortgagors or their representatives claimed that the economic crisis placed them in a moral dilemma. One can decide to accept their sincerity or be sceptical about their intentions to exploit the presumed Christian values of the hierarchy. In November 1882, A. J. R. Stewart's solicitor, Edward Murphy, wrote to the college bursar, Fr Andrew Boylan: ${ }^{39}$

\section{Rev \& Dear Sir,}

The Northern Bank have informed me that you retain the official receipt for interest due you by Mr Stewart, although they have remitted to you the usual amount.

35 A. W. Percival to Fr O'Hagan, 25 Feb. 1891 (MCA, 110/12). 36 F. M. Crozier to Edward Carraher, 7 Jan. 1881 (MCA, 109/3). 37 Irish Times, 14 Jan. 1881; An Irish Priest [Fr Thomas Conefrey?], A short history of the land war in Drumlish in 1881 (Dublin, 1892), pp 28-9, 51; Dooley, 'Landlords and mortgagees', p. 615. (Fr Conefrey later estimated that 300 families were evicted; see document 43.) 38 Drumlish land war centenary, 1881-1981: commemorative booklet (1981); see 'The land war in Drumlish' by 'The poet Higgins' in ibid., pp 39-40. 39 Andrew Boylan (1842-1910) was born in County Cavan. Ordained in 1867 , he became bursar in 1883 . He resigned in 1887 to join the Redemptorists and after a distinguished career as a missionary, he became bishop of Kilmore in 1907; Corish, Maynooth College, p. 443. 
I presume that you retain the receipt in order that the penal interest may be charged. I trust however that considering the circumstances of the country and that I could not have obtained the money due to you without unduly pressing the tenantry that your board will kindly consent to receive the money as usual. Had I proceeded against the tenants I would have put them to serious costs and injured their prospects of the present season greatly. I am sure if my friend Dr Farrelly is still connected with your board that he will explain to you how punctual this interest has always been paid and it is more on behalf of the poor people whom I should have had to press, than in Mr Stewart's interest that I ask you this favour.

I am Rev and Dear Sir,

Faithfully Yours,

Edward Murphy. $4^{\circ}$

As the documents below clearly illustrate, the first stage of the Land War certainly initiated long-term difficulties for Granard in regard to meeting his interest repayments to the college. The same was true of the other mortgagors. In December 1880, A. J. R. Stewart's solicitor, Edward Murphy, wrote to the bursar:

\section{My Dear Sir,}

You will no doubt be aware that even in the north of Ireland the tenants have combined against paying their rents. I am satisfied, however, that so soon as the intentions of the legislature in reference to the land question shall become fully known, this reluctance to pay will disappear; and I do not think it advisable, in the present state of the country, to resort to measures of coercion. Under these circumstances it occurs to me to ask you if you will permit the interest which will be due on the 1st proximo on the loan obtained from your board to stand over, without penal interest, until, say, the end of February.

Your compliance with this request will much oblige.

Truly yours,

Edward Murphy.41

Initially, such requests were favourably looked upon by the benevolent Farrelly. He replied to Murphy:

\section{My Dear Sir,}

I have received your letter of yesterday's date. I fully appreciate the grounds upon which you propose to let the payment of the interest on 1st proximo to stand over beyond your usual time of payment 'until say the end of 


\section{ARCHIVIUM HIBERNICUM}

February'. Your payments to us have been uniformly so prompt \& so satisfactory that I am very pleased to find that the payment may be deferred until the date named without incurring the liability to pay penal interest. Wishing you many happy New Years. I remain,

My Dear Sir,

Very Faithfully Yours,

[Farrelly].42

When government legislation arrived in the form of the land act of 1881 , what was arguably its most significant enactment - the establishment of the Irish Land Commission with the powers to set up courts to adjudicate on fair rents - was of more benefit to tenants than to landlords. ${ }^{43}$ Fair rents invariably meant lower rents, which, in turn, defused much of the agrarian agitation that had characterised the Land War of 1879 to 1882.44 It also further compounded mortgagors's financial difficulties: some of Granard's tenants, for example, had their rents reduced by up to 50 per cent or more. ${ }^{45}$ Moreover, the establishment of the principle of dual ownership undermined landlord authority. It restricted the likes of Granard's movements regarding evictions and after 1881 there were no more clearances on his estate, although 'a large number of writs' were certainly issued during the late 1880 os when the Plan of Campaign was established on the estate. ${ }^{46}$ Other landlords tried to pre-empt being brought before the courts by carrying out their own valuations and coming to a private arrangement with their tenants. Thus, in May 1882, Caledon Dolling, agent to Blayney Balfour of Townley Hall wrote to the bursar:

\section{My Dear Sir,}

It is usual at this date to pay you the half years' interest due Maynooth College by $\mathrm{Mr}$ Balfour. Owing to my having made propositions to the tenants to have a valuation made and which valuation has been slightly delayed, our valuator Mr Geo[rge] Taylor being so immensely engaged that it's nearly impossible to get him, and as I have such perfect confidence in his work and do not think it advisable to have any other person but would rather wait, our rent days therefore cannot be now but I expect they will be the end of this month. Am I asking too much if you will allow the payment to wait till the end of this month - it will convenience me much - I have great hope that I shall be able to settle with Mr Balfour's tenants but one

\footnotetext{
42 Copy letter from Fr Farrelly to Edward Murphy (MCA, 107/8). 4333 \& 34 Vict., c.xlvi (22 Aug. 1881). 44 From August 1881 to December 1902, the Land Commission courts dealt with 342,019 cases where they fixed judicial rents, on average, at almost 21 per cent below their previous levels; $A$ return showing according to provinces and counties the number of cases in which judicial rents have been fixed by all the matters provided by the Land Law Acts for a first and second statutory term respectively to 31 December 1902 with particulars as to acreage, former rents of holdings, and percentage of reductions in rents, HC 1903, lvii. 91. 45 Longford Independent, 11 Dec. 1886. 46 See document 19.
} 
cannot hurry it, so I shall be much obliged if you will give me the time required. 47

As the economic depression deepened and the college came under increased financial pressure, Rev James Farrelly was replaced as bursar by the more business-like Fr Andrew Boylan. In September 1882, Boylan wrote to Alexander Stewart's agent, in reply to the latter's request for a further abatement of interest:

Dear Sir,

I beg to enclose memo of interest due to the trustees of Maynooth College by A. J. R. Stewart esq[ui]re. I shall thank you to send me immediately a cheque for same as very great inconvenience has been caused to the college by the non-payment of this money at the time it fell due.

I wish further to state that it will be impossible for us to meet heavy and pressing demands unless you come promptly to our aid. I need hardly say that I regret having to write this letter but as the money is long overdue and especially as it is so much needed I could not act otherwise.

I remain,

Dear Sir,

Very Sincerely Yours,

Andrew Boylan..$^{8}$

The same year, in response to the growing crisis and as a concession to beleaguered landlords, the government passed the Settled Land Act (Ireland) 1882, which acknowledged their need to sell off assets and outlying estates in order to meet their charges. In the short term, the monies received from such sales secured much needed cash. In the long term, of course, this began the process of stripping Irish country houses of their valuable contents, a process that was to continue during the remainder of the nineteenth and throughout the twentieth centuries. On behalf of Stewart, Frank Browne wrote to P. A. Chance:

\section{Dear Sir,}

I think you act for the trustees of Maynooth College; if so the trustees hold a mortgage for $£ 55,000$ on the estate of Mr Stewart of Ards; and of course all of his title deeds are deposited with them. I am about to apply to the Court of Chancery for an order under the Settled Land Act, giving Mr Stewart liberty to sell certain plate and diamonds which are settled as heirlooms by a deed of re-settlement of 10th June 1873; and a deed modifying the trusts thereof of 27 th February 1874 . It will be necessary on this application to have these deeds in court. Would you therefore kindly arrange with the 
trustees to obtain these deeds so that you can produce them when required, and as I am in a position to make the application at once, I should feel obliged if you would kindly lose no time. I understand the trustees have already expressed to Mr Murphy, Mr Stewart's agent, their readiness to assist in the matter. Of course your charges will be paid.

Yours faithfully,

Frank Browne. 49

For about two years after 1882, the levels of correspondence once again diminish, reflecting the temporary recovery in the economy from 1882 to 1884 , the effects of the fair rent fixing courts, the easing of agrarian tensions and the contribution of the Settled Land Act of 1882 . The mortgagors became more optimistic. At the end of June 1883 , Edward Murphy wrote to Farrelly: 'I hope this is the last time I will have to ask [ for a postponement] for things are settling down'. He expected a good harvest and renewed ease in the collection of rents and so requested that the Stewart loan could be extended beyond 1884 , the year it was due to fall in..$^{\circ}$ However, in 1885, the agrarian crisis was renewed. Once again, a mass movement, this time directed by the National League, grew in response. Its most potent weapon was the Plan of Campaign..$^{11}$ Those who orchestrated the plan called for rent reductions on individual estates. If these were not granted the whole body of tenants were to strike against the payment of any rents and to pool them instead into a common fund to be used in the event of landlord retaliation in the form of evictions. At local level, priests were very much to the fore. In March 1888, Philip Smyth, agent on the O'Reilly estate, who was having difficulties getting rents in on time 'on account of the organised opposition to the payment of rent aided and assisted by influential parties', ${ }^{2}$ wrote to Fr Donellan:53

Dear Father Donnellan,

I received your letter of the ist inst before leaving [the] house. I now enclose you [a] cheque for $£ 137: 15$, the interest less $£ 4: 15$ income tax. You may use the cheque when you please. I thank you however for saying you would hold it three days to suit my purposes.

I may well exclaim 'save me from my friends the college finance committee' and some priests down here one of whom as president of a Land League has prevent (sic) a tenant oweing (sic) me $4^{\mathrm{T} / 2}$ years rent to settle it and get an abatement of 4 / in the $£$ by engaging the Land League solicitor to defend his case which he did by asking time for payment until the sst inst.

49 Frank Browne to P. A. Chance, n.d. (MCA, 109/2). 50 Edward Murphy to Fr Farrelly, 30 June 1883 (MCA, 107/8). 5r See Laurence Geary, The Plan of Campaign, 1885-91 (Cork, 1985). 52 Philip Smyth to Fr James Donnellan, 20 Sept. 1888 (MCA, 108/13). 53 James Donnellan (1856-1932) was born in County Roscommon. He became bursar in 1887 and held the position until his retirement in 1923. He oversaw the extensive modernization of the college at the turn of the century; Corish, Maynooth College, p. 453. 
Letters will find me here [Colmanstown House, Ballinasloe, County Galway] until Wednesday, after Ashtina, Tullyco, Cootehill [County Cavan].

Yours truly,

Philip Smyth. ${ }^{54}$

The renewal of economic depression and agitation was disastrous for most of the mortgagors. By December 1886, accumulated arrears of rent of over $£ 22,000$ were owed on the Stewart estate; the agent reported that 'the tenants are holding back'. ${ }^{55} \mathrm{~A}$ receiver had been appointed on the estate earlier that year who had reported to the trustees:

\section{Dear Sir,}

Stewart's estate. I am obliged by your note - I see that the account of this estate is very considerably worse than it was at this time last year. I am afraid we can do nothing unless Mr Murphy can collect sufficient rents. ${ }^{56}$

The college authorities were becoming increasingly concerned. Boylan was determined to ensure that he was not being deceived. In March 1887, he wrote to the receiver on the Stewart estate:

\section{Dear Sir,}

Kindly inform the agents of the Stewart estate that I wish to have official information from them on the exact am[oun]t of rents received since Jan[uary] 1 1886. The college solicitor is Mr Chance M.P. and I am thinking of going down with him to examine the state of the acc[oun]ts as far as we are allowed to do so. If the $\mathrm{a} / \mathrm{c}$ allows it, please send cheque for balance due, £564:17:11. 57

Boylan and the trustees were having most difficulty with the Granard estate. By 1883 , the trustees had not received a payment of interest on the appointed gale days since $1880.5^{8}$ Granard's high levels of incumbrances made it an obvious target for the Plan of Campaign; there was a general sense amongst its organisers that indebted landlords would succumb more readily to its demands. In early December 1886 , an estimated 500 of Granard's tenants marched to Longford town. They were headed by the Killoe fife and drum band, and led by Fr Thomas Conefrey; Fr John Briody, parish priest of Killoe and Fr Denis Grey, curate of Ballinamuck. Outside the Longford Arms Hotel, the tenants demanded reductions of 30 per cent on all judicial rents and 40 per cent on all non-judicial rents. Granard's agents, Darley and Roe, refused reduction on judicial rents (assuming that the tenants had already received a fair reduction from the land

54 Philip Smyth to Fr James Donnellan, 3 Mar. 1888 (MCA, 108/13). 55 Edward Murphy to Fr Boylan, 6 Dec. 1885 (MCA, 107/8). 56 Kyle Knox to Fr Andrew Boylan, 22 Feb. 1886 (MCA, 107/8). 57 Copy letter Fr Andrew Boylan to Kyle Knox, 21 Mar. 1887 (MCA, 107/8). 58 Statement of Lord Granard's interest account since May 1880 (MCA, 110/16). 
courts) and offered only 15 per cent on non-judicial rents. The tenants withdrew without paying any and at a subsequent meeting resolved that 'they were determined to stand by the Plan of Campaign'.59 The documents below suggest that their resolve did not last long, but Granard continued to impress upon the trustees that his rents were not coming in and that he was, therefore, unable to meet his obligations.

Not all of the mortgagors were affected to the same degree. The most obvious exception was Lord Cloncurry. His relationship with the tenants on his Limerick estate had been soured by his refusal to grants them reductions in 1881 . He told them that year:

The annual sum which I pay to the trustees of Maynooth Roman Catholic College in interest upon mortgages of land in Ireland is as large as the whole rental of my property in Limerick, and if you can persuade the trustees of Maynooth College to give me an abatement of 20 per cent in the half year's interest now accruing to them I will have pleasure in giving a similar abatement to my tenants in Limerick. ${ }^{60}$

But although the Plan of Campaign was established on his Limerick estate, greatly diminishing his rental income for the years $1885-89,{ }^{61}$ he had relatively little difficulty in collecting rents on his Kildare and Dublin estates and so his relationship with the college trustees was so unaffected as to allow him the confidence to write in 1886 :

If you are at any time placed in difficulty by the temporary failure of other payments due to the trustees of your college, I hope that you will write to me even though interest may not be fully due at the time ... and although I do not leave money idle at current account, I hope to be always able to send to you a remittance through my bankers, or stockbrokers without any trouble or inconvenience and at a few days' notice. ${ }^{62}$

By the mid-188os, the other of the college's mortgagors had to face simultaneously falling rental incomes, increased indebtedness and demands from the trustees not only for the payment of interest but, particularly in Granard's case, the payment of principal as well. With all avenues of future borrowing effectively closed to them, they had no option but to consider the sale of their estates as the only viable means of survival.

By the early twentieth century, most of the mortgagors had sold their estates under the land acts of $1881-1909$ and had repaid their mortgage loans. Once again, the mortgage papers are important in this respect. First of all, they reveal the obvious pressure upon indebted landlords to sell their estates in order to remain solvent. But more importantly, they reveal the intricacies involved in 
negotiating these sales, particularly prior to the passing of the Wyndham Act in 1903. Until then, the mechanics of the earlier land acts did not encourage a largescale transfer of landownership. The land act of 1881 resulted in the transfer of ownership of only 730 holdings, principally because tenants had to raise a 25 per cent cash deposit, which only a minority of the well-to-do could afford, and landlords demanded more than tenants were prepared to offer at a time when the Land Commission were lowering their rents. ${ }^{63}$

The land act of 1885 was more progressive. ${ }^{64}$ Tenants could be offered the full advance necessary to purchase their holding, but as we shall see in the Granard documents, the Irish Land Commission was often reluctant to do so because of the fear that a potentially uneconomic holding would not sustain the repayment of annuities into the future. The other downside operating against landlords was that one fifth of the purchase price of the holding was retained by the commission as a 'guaranteed deposit' for fifteen years which could be used to make good any default by tenant purchasers in the payment of their annuity. There was a sense amongst landlords, and indeed a very real possibility, that some landlords, particularly those whose estates were composed of marginal holdings, would never realise the full value of their estates once sold. In 1886, an assistant land commissioner, James Houghton, told the Cowper Commission:

Landlords are obliged in prudence to demand on account of the one fifth deposit, a greater number of years purchase than they would be contented with if the whole money was to be paid down on the nail, because they have no guarantee that they will ever receive that one fifth, seeing that if the instalments are unpaid, the commission will draw on it, and at the end of the fifteen years it may be nil, so that a person who may be willing to sell his land at twenty years' purchase calculates that he is getting only sixteen years' purchase. ${ }^{65}$

Many of the documents reproduced below deal with the sale of the Granard estate from the late 1880 os. They show that Granard's hand was effectively forced by the trustees as his debts to the college mounted. They demonstrate the wheeling and dealing that occurred on both sides in order to secure the carriage of the sale. Justice Monroe's ruling on the carriage is interesting in that it reveals that Granard was receiving much more in rents, even at the height of the Plan of Campaign, that he was not admitting to, that other mortgagors were given priority over the trustees and that the trustees themselves were not entirely in agreement as to the action that should be taken against Granard. ${ }^{66}$ Significantly, there was also a considerable rise in family charges since the mortgage had been acquired: in 1871 , Granard had been married for thirteen years but had no

6333 and 34 Vict., c. xlvi (22 Aug. 1881); Terence Dooley, 'Landlords and the land question, 1879-1909' in Carla King (ed.), Famine, land and culture in Ireland (Dublin, 2000), pp 126-7. 6444 and 45 Vict., c. cxlviii (22 Aug. 1885). 65 Report of the Royal Commission on the Land Law (Ireland) Act, 1881, and the Purchase of Land (Ireland) Act, 1885, minutes of evidence and appendices [C4969], HC 1887, xxvi. 25, p. 32.66 See document 24. 
children; by 1888 he had married for the second time and had five sons. The documents also show the difficulties which arose when the Land Commission refused to advance the purchase money to uneconomic holders, particularly those in the Drumlish area, where, according to one contemporary report, the tenants 'appeared to be in a great state of destitution and the land ... is so bad that it would be impossible for a person to derive a livelihood from 100 acres without even the payment of any rent'. In the end, it took a great deal of local manoeuvring under the astute guidance of Fr Thomas Conefrey, the willingness of the trustees to travel to Longford and set up a commission to look at the cases of holdings that were proving difficult to sell, and the recognition by the trustees that they would ultimately have to write off a substantial proportion of the loan (in the region of $\{40,000)^{67}$ to resolve the issues involved. In 1892 , the less than objective 'Parish Priest' (probably Fr Conefrey himself), wrote in A short history of the land war in Drumlish in 1881:

... it is my pleasing duty to narrate that the tenants ... have achieved a complete, permanent and final victory. They have nearly all bought out their farms under the Ashbourne act at a price that leaves them their farms at mere nominal rent. The trustees of Maynooth College, who have a heavy mortgage on Lord Granard's estate, and who are in reality the real owners, true to the Christian spirit of their high calling, showed every anxiety, and used every means in their power to enable Father Conefrey to buy out the farms for the tenants on such terms as would enable the latter to support their families in comparative comfort. Through the trustees of the college, Fr Conefrey got several years of arrears of rack-rent forgiven. ${ }^{68}$

The background to these developments is elucidated in the documents produced below. In the end the trustees seem to have accepted that it would be futile attempting to sell the castle and demesne; it would be difficult to sell the former and what would be secured from the sale of the latter 'would be insufficient to pay the monies still due to the trustees on foot of their several incumbrances'. ${ }^{69}$

The fortunes of the Granards were rescued in 1909 when the eighth earl married an American heiress, Beatrice Ogden Mills. Her dowry enabled the Granards to continue to reside at Castleforbes and, indeed, to restore the castle to all its former glory. ${ }^{70}$ Had the family been able to hold out, the 1903 Land Act would have treated them (and, indeed, their tenants) much more kindly. ${ }^{71}$ The 1903 act was much more enticing to landlords and tenants, thereby contributing to a revolutionary but by no means complete transfer of landownership from landlords to tenant farmers..$^{72}$ Tenants were guaranteed that their future annuity payments would be appreciably less than their former rents, while landlords were

67 Corish, Maynooth College, p. 184. 68 An Irish Priest, Land War in Drumlish, p. 55. 69 Statement regarding the earl of Granard's estate laid before the trustees of Maynooth College, June 1906 (MCA, 110/ 14). 70 Mark Bence-Jones, Twilight of the ascendancy (London, 1987), p. 69; id., A guide to Irish country houses (London, 1988 ed.), p. 67. 7I 3 Ed., cxxxvii (1 Nov. 1903). 72 See Terence Dooley, 'The land for the people': the land question in independent Ireland (Dublin, 2004). 
given a 12 per cent cash bonus on the sale of their estates and allowed to sell their demesnes and untenanted estates to the Land Commission for a price of up to $£ 20,000$ and then repurchase them under the same terms as their tenants, thereby securing what was in effect a long-term low-interest loan. ${ }^{73} \mathrm{E}$. O'Farrell, a member of the Land Commission, wrote to the trustees in October 1908, regarding the Balfour estate:

Sirs,

I am directed by the estates commissioners to notify you that the purchase money of the demesne of the above estate, amounting to the sum of $£ 14,000$ has been paid into the Bank of Ireland to the credit of the above estate, and an order has been made attaching claims thereto and fixing 1 Oct[ober] as the closing day.

Your obedient servant,

\section{E. O'Farrell.74}

By then, the Granards had only around 340 acres of their estate to sell, the same land that had been deemed impossible to sell under earlier acts. ${ }^{75}$

But despite the enticements on offer, there remained those landlords such as Lord Cloncurry who had no great desire to divest themselves of their entire tenanted estates in favour of an income derived from investments. As a consequence of their retention of tenanted and untenanted estates, the revolutionary period 1917-23 was a difficult one for many such landlords. ${ }^{76}$ Rents were withheld by tenants on many estates in the belief that independence would bring about the compulsory acquisition of lands by a Dublin parliament and that the occupying tenants would have to pay little or nothing for them. Such was the case on Cloncurry's Limerick estate where agitation had largely failed to abate since the Land War and Plan of Campaign days and where his tenants paid no rents in 1921 and $1922 .{ }^{77} \mathrm{Up}$ to the early $1920 \mathrm{~s}$, Cloncurry had paid off small amounts of principal from the sale of small parcels of land to district councils in Kildare chiefly for the erection of labourers' cottages. In October 1920, as the post-war economy fall flat, the trustees of the college resolved 'to determine, by a year's notice, their mortgage loan of $£ 66,300$ to the Rt. Hon. Lord Cloncurry, or as an alternative, to require the mortgagee (sic) to pay ordinary interest on said loans at the rate of $7 \%$ per annum. ${ }^{78}$ This raised interest repayments to $£ 1,551$ per half year. ${ }^{79}$ To meet them in the short term, Cloncurry agreed to sell part of the lands of Farnane and Ahacane to the occupying tenant, Patrick Ryan, for $£ 10,000$ in early $1921 .^{80}$ For the long term, Cloncurry asked that he be allowed to keep the loans outstanding 'on his undertaking to pay interest at the current rate from time

733 Ed., cxxxvii (1 Nov. 1903). 74 E. O'Farrell to trustees of Maynooth College, I Oct. 1908 (MCA, 107/6). 75 Dooley, Decline of the big house, p. 114. 76 See Dooley, The decline of the big house, pp 171-207. 77 Lord Cloncurry to 'acting bursar', 10 Aug. 1923 (MCA, C7/112/11). 78 Enclosed in ibid. 79 Financial report for year ended 31 Mar. 1921, p. 12. 80 White and White (sols.) to O'Hagan and Sons, 20 Jan. 1921 (MCA, C7/ $112 / 10)$. 
to time, charged by the banks', which were around 1 per cent less. The trustees were not entirely satisfied with this offer. Negotiations were entered into with Cloncurry's solicitors and it was ultimately agreed that Cloncurry would pay the rate of 7 per cent for 1921 and that he would pay the current bank rates in the future providing these rates did not fall below 6.25 per cent. There were serious penalties for default. In the event of the interest repayments being more than thirty days late, Cloncurry would have to pay additional interest at 15 per cent. Any future sales of his property had to go towards the diminishing of the loan principal. ${ }^{81}$ Thus, in April and June 1922, the principal was decreased to $£ 58,647$ from the sale of lands. ${ }^{82}$

The terms of the 1923 Land Act brought further complications. ${ }^{83}$ Under it the trustees were not allowed to recover penal interest either in respect of the arrears of interest due at the date of the passing of the act ( 9 August 1923) or in respect of the interest since accrued. ${ }^{84}$ By the end of 1923 , Cloncurry was $£^{2,700}$ in arrears. This was the first time in forty years of dealing with the trustees that he had been seriously in arrears. That December he wrote to the trustees:

\section{Dear Sir,}

I have received your letter and I regret all the causes that have prevented the punctual payment of the interest in the present year. For more than forty years I paid the half yearly interest with strict punctuality. The bursar never had to apply for any money that was overdue and our business relations were on a friendly basis. I was therefore surprised and disappointed when your trustees took advantage of the monetary confusion caused by the war $\&$ demanded the enormous increase of $50 \%$ in the rate of interest. No doubt they acted within their legal rights, but they have forced me to do the same, and to take advantage of the Irish Land Act 1923 so far as it relates to the payment of charges on land. I paid interest in full to your trustees for the years 1921 \& 1922 although the tenants on my land in County Limerick paid no rent in those years \& the land commissioners have, for so far, paid nothing to me on account of compounded arrears. I shall pay over to your trustees the first monies I receive from the commissioners in respect of rent or arrears. You must be aware that I am now prevented by law from collecting rent arising from land and am therefore also prevented from paying the charges upon the land. I may add that my solicitors advise me there is no authority for the demand or claim of $£ 42: 8: 5$ in addition to the half year's rent.

Faithfully yours,

Cloncurry. ${ }^{85}$

8I R. Ryan to Rev James Donnellan, 22 Oct. 1921 (MCA, C7/112/10). 82 R. Ryan to Rev James Donnellan, 3 April 1922; R. Ryan to Rev James Donnellan, 14 June 1922 (MCA, C7/112/10). 83 1923/42 [I.F.S.] (9 Aug. 1923). 84 Ibid. ; R. Ryan to Fr J. R. Maguire, 19 June 1924 (MCA, C7/112/10). 85 Lord Cloncurry to Fr J. R. Maguire, 5 Dec. 1923 (MCA, 112/11). 
The failure of Cloncurry to pay his interest punctually impacted upon the financial running of the college. While the 1890 s had been characterised by low prices and the trustees realised an annual surplus of around $£ 5,000$ per annum to invest, prices rose in the years leading up to the Great War, which, fed by wartime inflation, meant that by 1915 net income was appreciably lower than a few years before. The purchase of lands, installation of electricity, the extension of the college heating system, a new sanitary system and the building of a swimming pool in the years before the war had meant expenditure in the region of $£ 40,000$ that had been raised through borrowing. The economic depression that followed the war had further detrimental consequences for the college finances as farming was thrown into disarray and agricultural prices collapsed. ${ }^{86}$ In March 1924, the bursar, Fr J. R. Maguire, ${ }^{87}$ wrote to Cloncurry:

My Lord,

I shall esteem it a favour if you can inform me, when you expect to be in a position to lodge the amount of the interest due. My reason for asking, is that I am now preparing returns for the purpose of getting refund of income tax deducted at the source, and I should like to include all possible deductions, as otherwise the amount unclaimed should be outstanding for another twelve months. I am sorry to say the college finances are not strong, and I have some anxiety on the matter, more especially as I am just taking over the responsibilities of the office of bursar.

I may tell you in confidence that our overdraft with the bankers is presently nearly $£^{20}, 000$. Hence your lordship will see a reason for my request. I have the honour to be,

My lord,

Your lordship's obed[ien]t serv[an]t,

J. R. Maguire.

Most significantly, the terms of the 1923 Land Act introduced the principle of compulsory acquisition of lands in order to redistribute them amongst uneconomic holders in their vicinity or amongst congests who might have migrated to an area. Traditional landlords who continued to retain large tracts of untenanted estates were the first to have their lands acquired. ${ }^{88}$ By 1926 the Land Commission had acquisitioned a large part of the Cloncurry estate 'at a very nominal sum' (a reference by Cloncurry's solicitors to the fact that payment in 4.5 per cent land bonds was not willingly accepted) and that Cloncurry was now not able 'to adjust his income and outgoings. ${ }^{, 89}$

86 See Corish, Maynooth College, pp 268-9. 87 J. R. Maguire (1877-1948) was born in the diocese of Clogher. He was ordained in 1902 and became bursar in 1923, having served the previous four years as assistant bursar. He resigned in 1944 because of failing health; Corish, Maynooth College, p. 471. 88 Dooley, 'The land for the people', chapter 2. 89 Copy letter White and White to O'Hagan and Sons, 25 Aug. 1926 (MCA, C7/112/12). 
Lord Cloncurry died on 12 February 1928. At that stage the principal on the Lyons estate mortgage stood at $£ 37,350$ while the principal on the Limerick mortgage stood at $£ 15,400.9^{\circ}$ Under the terms of a deed of family settlement executed in 1867 and of Lord Cloncurry's will his daughter, the Hon. Kathleen Lawless, succeeded to the Lyons estate, while his brother who succeeded him as Lord Cloncurry, succeeded to the Limerick estate. Both inherited the respective mortgages and almost immediately both sought an interest reduction to a rate of 5 per cent. ${ }^{11}$ Again it was pointed out to the trustees that the passing of the 1923 Land Act 'reduced Lord Cloncurry's rents by 25 per cent' and that 'the agricultural depression has affected owners of land who occupied and farmed same themselves to a very serious extent'. ${ }^{2}$ From the late 1920 s and through the 1930 , the Land Commission continued to acquire by compulsory purchase the Cloncurry estates in Kildare, Dublin and Limerick piece by piece and the land bonds that were secured from the sales were transferred to the college trustees. ${ }^{93}$ By the late 1930s, the mortgage loans had eventually been paid off. Almost seventy years before, the magnitude of the changes that were to take place in the system of landownership in Ireland with all its attendant consequences could scarcely have been imagined by either the college trustees or those who had been offered mortgage loans.

\section{The correspondence concerning Maynooth College and the Granard estate, 1872-1907}

I

Loans by the college of Maynooth: abstract of mortgage deeds prepared by Edward Carraher, n.d. MCA, 112/16

1. Assignment of mortgage dated 19th day of April 1872 from Thomas P. Williams and others and the earl of Granard to the trustees of the college of Maynooth to secure the sum of $£ 91,592: 7: 2$ and interest thereon at the rate of $£$ 4:15:0 per cent per annum reducible to $£ 4: 5$ : 0 if paid within 60 [days] after each of the gale days which are the 11th day of May and 11th day of November. The estates mortgaged are situate in the counties of Leitrim and Longford and are of the annual value of $£ 8,973: 10: 2$. Principal money not to be paid off or called in until the 11 th day of May $1892 \& 12$ months' notice. 94

90 R. Ryan to Fr J.R. Maguire, 28 Feb. 1928 (MCA, C7/112/12). 9I White and White to O'Hagan and Sons, 18 Feb. 1928 (MCA, C7/112/13). 92 Copy letter White and White to O'Hagan and Sons, 27 Feb. 1928 (MCA, C7/112/13). 93 Copy letter White and White to O'Hagan and Sons, 4 May 1928; R. Ryan to Fr J.R. Maguire, 8 July 1929 (MCA, C7/112/13); White and White to O'Hagan and Sons, 6 May 1936; Richard Ryan to Fr J.R. Maguire, 26 May 1936; copy letter Fr J.R. Maguire to Richard Ryan, 26 May 1936; Richard Ryan to Fr J.R. Maguire, 25 Nov. 1936 (MCA, Maguire papers, Box 305/43); Report of the president, 1932-33, p. 4; Financial report for year ended 31 Mar. 1935, p. 2; Financial report for year ended 31 Mar. 1936, p. 2. 94 For information on conveyancing of the estate, see document $\sigma_{1}$. 
2. Assignment of mortgage dated 8th day of October 1873 from William E. Scott and others and Blayney Townley Balfour to the trustees of the college of Maynooth to secure the sum of $£ 25,000$ and interest at the rate of $£ 5$ per cent per annum reducible to $£$ 4:5:0 if paid within 60 days after each of the gale days, which are the 8th day of April \& 8th day of October. The estates mortgaged are situate in the counties of Louth and Meath and town of Drogheda. Annual rental $£ 4,006$, outgoings $£ 464$. Loan not to be paid off or called in for 20 years from date of mortgage.

3. Mortgage (assignment of) dated 3rd December 1873 from John Brennan and Myles W[illia]m O'Reilly to the trustees to secure the sum of $£ 6,000$ and interest at $£ 6$ per cent per annum reducible to $£$ 4:15:0 if paid within 60 days after each gale day, 3 rd June and 3 December. The estates are in the counties of Galway and Louth and produce a net annual rental of $£ 2,000$. Loan not to be paid off for 20 years from 1st October 1873 and 12 months' notice to be given.

4. Mortgage dated 28th day of February 1874 from Alexander John Robert Stewart and his eldest son Alex[ande]r George John Stewart to the trustees. To secure the sum of $£ 55,000$ and interest at 55 per cent reducible to $4 \% \frac{1}{4}$ if paid within 60 days after each gale day 1st January and ist July. The estates are situate in the counties of Down and Donegal and produce a net annual rental of $£ 4,429$. Loan not to be paid off or called in until the 1st January 1884 and 12 months' notice to be given.

5. Mortgage dated [blank] day of June 1874 from Valentine Frederick Lord Cloncurry to the trustees to secure the sum of $£ 45,000$ and interest at 5 per cent reducible to $4 \frac{1}{4}$ per cent if paid within 60 days after each of the gale days 28th May and 20 Nov[embe]r. The estate, which is known as the 'Lyons estate', is situate in the counties of Dublin and Kildare and is of the estimated net annual value of $£ 4,313$. Loan not to be paid off or called in until the 2oth November 1883 and 12 months' notice to be given.

6. Mortgage dated [blank] day of June 1874 from Lord Cloncurry and his trustee (sic) to the trustees to secure the sum of $£ 25,000$ and interest at 5 per cent reducible to $4^{\mathrm{T} / 4}$ per cent if paid within 60 days after each of the gale days ment[ione]d in last deed. This estate is known as the 'Limerick estate' and produces a net annual rental of $£ 3,400: 15$ :0. Loan not to be paid off or called in until the 2oth November 1883 and 12 months' notice to be given.

7. Mortgage dated [blank] day of June 1874 Lord Cloncurry to the trustees to secure the sum of $£ 25,000$ and interest at $5^{1 / 2}$ per cent reducible to $4^{1 / 2}$ per cent if paid within 6o days after each gale day, 28th May and 28th November. This estate is known as the 'Cloncurry estate' and produces a net annual rental of $£ 2,603$ :11:7. Loan not to be paid off or called in until the 28th day of May 1879 and 12 months' notice to be given. 
2

Edward Carraher to Rev Farrelly, 1 February 1871

$$
\text { MCA, 109/1 }
$$

My Dear Dr Farrelly,

I have been applied to by a firm of solicitors here for a loan of $£ 90,213: 3: 10$ if the trustees can lend same in mortgage at $£ 4.5 .0$ per cent. Rental $£ 9,040$.

I tried to speak to [?] O'Hagan on the subject but he was engaged in Court of Chancery. The borrower is one whom the trustees I think would, if possible, be anxious to deal with. If in town tomorrow you might give me a call.

Sincerely yours,

Edward Carraher.

3

Particulars of security for proposed loan on the Longford and Leitrim estate of the Right Honorable the earl of Granard [c. Feb. 1871]

$$
\text { MCA, 109/1 }
$$

The Longford estate containing 13,171 a. 2 r. 23 p statute measure or thereabouts exclusive of the demesne of Castleforbes produces an annual rental of

Bog rents

The demesne which is in the hands of his lordship contains 1,865 [acres] $3 r$ [oods] 36 p[erches] like measure and was valued by Messrs Brassington and Gale in 1859 at the yearly value of $\quad £ 867.5 .11$

But a small part known as Kennedy's Island is not to be included in the security.

The Leitrim estate contains 4,605 a[cres] 1r[ood] 4p[erches] statute measure and produces an annual rental of $£^{2090.7 .5}$

The valuation of Brassington and Gale of woods on hands was $£ 27.11 .7$

$£ 9840.16 .1$

Outgoings

An annuity for life of owner's aunt the Lady Selina Caroline Forbes who is very advanced in life Tithe rent charges 
MORTGAGE PAPERS OF ST PATRICK'S COLLEGE, MAYNOOTH, I87I-I923

Quit rents

$£ 59.15 .0$

Head rent

$£ 7.7 .9$

Drainage instalments (terminable)

$£ 780.13 .6$

$£ 9060.2 .7$

The estates are subject to a jointure annuity of $£ 1,200$ to the viscountess Forbes the owner's mother who is advanced in life, but proposed loan has priority over said annuity - and are also subject to a charge of $£ 5000$ in favour of the Honorable William Forbes the owner's brother, but which is also puisne to proposed loan.

The owner now requires a loan of $£ 91,592.7 .2$ to pay off a sum of $£ 90,213.3 .10$ and of $£ 1,379.3 .4$ a subsisting charge by mortgage now affecting the said estates and are secured by mortgages now affecting the said estates and are secured by mortgages on a trust term of 900 years created by the will of Viscount Forbes the owner's father, and now vested in his grace the duke of Leinster 95 the surviving trustee of said will.

Since the valuation made by Messrs Brassington and Gale a considerable expenditure amounting to some thousands of pounds has been made on the castle and demesne of Castleforbes.

\section{4}

Edward Carraher to Dr Farrelly, 7 January 1881

$$
\text { MCA, } 109 / 3
$$

My Dear Dr Farrelly,

Enclosed you have copy letter from Mr Crozier and copy of a letter from a process server. The contents of either do not at all surprise me as I was already aware that no rents had been paid to his lordship: any tenants willing to pay were afraid to do so. And such being the case of course Lord Granard is not in funds to pay the trustees. And I cannot see anything for them to do but accede to Mr Crozier's proposal and wait for some little time to see will things mend.

In my opinion matters will be much worse before they are better.

Yours Faithfully,

Edward Carraher.

95 Augustus Frederick FitzGerald, third Duke of Leinster (1791-1874), who resided in Carton near Maynooth, was owner of over 73,000 acres in Kildare and Meath; Bateman, Great landowners, p. 265. 
5

Copy F. R. Crozier to Edward Carraher, 7 January 1881

MCA, 109/3

\section{My Dear Sir,}

From our previous interviews you are already aware that I have not been receiving any rent on Lord Granard's estates.

The tenants came to me in a body, asking to be reduced to Griffith's valuation. But this could not be, in justice to Lord Granard, acceded to.

His lordship last year gave a reduction of 20 per cent and expended something about $£ 4,500$ in drainage and other improvements, \& except in two loans of $£ 100$ each, one being to the bailiff, no interest was proposed to be charged for this outlay.

His lordship is taking active steps to compel payment, but I fear that the influence of the Land League is so great that it will be impossible to make any practical use of any decrees that may be obtained - until things settle down.

I need hardly say that this state of affairs has caused serious inconvenience to his lordship and difficulty to me to manage the estate affairs.

I am quite aware that the trustees of the college of Maynooth require their interest in order to enable them to carry on their establishment but I am sure that knowing the present state of the country they will feel for his lordship.

If it will meet their views I would propose to pay half the interest and the remainder out of the very first rents that come to my hands.

Perhaps you would kindly communicate with the trustees - and let me have their reply.

I enclose you a letter from the only process server in the Co Leitrim who had consented up to recently to serve processes.

It is to be hoped however that the government measures about to be brought forward will restore order and I am happy to feel that many of the tenants are willing to pay if they would be permitted.

I remain,

Yours faithfully,

Francis R. N. Crozier 
MORTGAGE PAPERS OF ST PATRICK'S COLLEGE, MAYNOOTH, I87I-I923

6

Copy of letter from James Coleman to Edward Carraher, 30 December 1880

$$
\text { MCA, 109/3 }
$$

My Dear Sir,

In reply of yours this morning I am sure it would be utterly impossible to serve processes particularly for rent, at the present state of the country or state of affairs, in fact the people in this neighbourhood are all up in arms against any document to be served on them. I cannot go out through the country even for civil bills for shop goods. Not one in the town could go to rest last night from 11 o'clock - the music \& drums commenced - filled the town with people from all parts of the country - also the green was filled with bands \& drums. We thought the country was mad at least the people. I regret exceedingly to see the country in such a bad state.

Hoping for peace soon - I am dear sir,

Yours respectfully,

James Coleman.

\section{7}

Francis Crozier to Rev Farrelly, 7 July 1881

$$
\text { MCA, } 110 / 16
$$

\section{My Dear Sir,}

Lord Granard came to town today specially to see me about the interest which should be now paid to the College. I can assure you that I have had the greatest difficulty in trying to get rent from the tenants, as even the tempting offer of 20 per cent was not availed of by many, and the consequence is that the arrears have largely increased. I am making arrangements to procure the money but it will necessarily take a short time $\&$ I trust therefore that the trustees will give his lordship a short time to complete his arrangements. He will have no objection to pay interest on this money for the overdue period i.e. compound interest. A [reply?] by return will oblige.

Yours very faithfully,

Francis Crozier. 


\section{ARCHIVIUM HIBERNICUM}

\section{8}

Francis Crozier to Rev Boylan, 11 October 1882

$$
\text { MCA, 110-16 }
$$

\section{Dear Sir,}

I would have replied to your letter sooner only that I had an office fixed for last Saturday at Longford and I was anxious to see whether the tenants would pay their rents \& place Lord Granard in a position to discharge his debt to the college, the delay having already caused both him and myself considerable anxiety.

Large numbers attended for the purpose of enquiring whether his lordship would join them in applying for the benefit of the Act \& which I informed them would be done. I am having the necessary forms prepared and will have them completed with as little delay as possible but until I get them completed by the tenants, I do not expect I will get any money to signify.

I regret much the inconvenience the college has been caused, but it is owing simply to the effect of the Arrears Bill ${ }^{6}$ on the tenants \& from no other cause.

I remain,

Yours very faithfully,

Francis Crozier.

\section{9}

Rev Andrew Boylan to Darley Q Roe, 17 January 1887

MCA, $110 / 17$

\section{Gentlemen,}

Please send me on [even?] $£ 500$ as soon as possible. We want money very much at present, and we relied chiefly on you to enable us to satisfy our pressing claims. As the interest was not paid before 1th inst the matter must be reported to our trustees but if you settle at this 12 Feb[ruary] I suppose they must be satisfied.

Very truly yours,

Andrew Boylan. 
MORTGAGE PAPERS OF ST PATRICK'S COLLEGE, MAYNOOTH, I87I-I923

IO

Darley and Roe to Dr Robert Browne, 97 President of Maynooth College, 13 May 1887

$$
\text { MCA, } 110 / 17
$$

Sir,

We have to state that we never alleged to mortgagees of Lord Granard's estate, meaning the trustees of Maynooth College 'pressed the matter to the extreme of evictions' as reported to have been stated by Colonel KingHarman [in parliament] and which you quote in your letter of the 1th instant. So far as we can ascertain the source from which Colonel KingHarman obtained his information was Captain Butler R. M., Mullingar. It having been reported to the government that a number of the tenants round Drumlish who had received notice of evictions were poor, he was, as we are informed, directed to enquire into the circumstances of their cases. He called on us and we informed him that we could not further postpone the evictions as the tenants had struck against paying rent and the estate charges must be met, the principal one being for interest due to the trustees of Maynooth.

When we spoke on the subject we stated that the trustees had not unduly pressed us.

With reference to a further statement attributed to Colonel KingHarman on Monday evening last 'that he had received information from us as to the sum and conditions of the mortgage' we have had no communication with him on that subject and we distinctly deny that we have given the information referred to, and which if we had done would in our opinion have been a great breach of confidence.

Yours obediently,

Darley \& Roe

97 Robert Browne (1844-1935) was born in County Cork. He was ordained in 1869 and became president in 1885. With limited resources, he managed to greatly improve the infrastructure of the college. He was appointed bishop of Cloyne in 1894; Corish, Maynooth College, p. 445. 


\author{
II \\ John George MacCarth $y^{98}$ to President Browne, 13 May 1887 \\ MCA, $119 / 19$ \\ [Marked 'non-official']
}

\title{
My Dear Dr Browne,
}

Would it not be a good way out of the difficulty in Lord Granard's case to arrange for a sale of a sufficient part of the estate to the tenants under the Land Purchase Act?

Thus you would get your money and his lordship would be saved the necessity of evicting.

If you think so, I would suggest that Mr George Fottrell should be consulted. He has carried out many large sales with great skill and with solid advantage to all concerned.

Yours faithfully,

John George MacCarthy

12

\section{P. A. Chance to Dr Browne, 1 November 1887}

MCA, $109 / 3$

\section{Dear Dr Browne,}

On receipt of your telegram re[garding] Granard, I telephoned to His Grace but was informed that he would be absent until four o'clock.

Later, I saw His Grace and informed him of the contents of your telegram \& letter. I pointed out, that if the interest due was paid up, no petition for sale could be presented till, I think, 1894 , unless the interest again fell into arrears sixty days or more; and that it was possible that Lord Granard might continue paying interest, and decline to assist in a sale to his tenants, unless the trustees agreed to allow him to retain for himself some portion of the purchase money. This position would be very unfortunate, if, as is possible, the prospects of realising a considerable sum as purchase money, diminished from time to time, or a scheme for compulsory purchase - paying by bonds etc. - was in the air.

I therefore advised his grace to utilize the fact that interest was overdue and that thereby the condition against sale by the mortgages till 1894 was suspended, to point out to Lord Granard that the resolution of the board would be disregarded and become inoperative if payment were accepted; 
and put it to him would he sign a waiver of the condition preventing the mortgagors selling, if the trustees assented to his paying the interest as he could.

I have ascertained that Lord Granard has made overtures to the tenants as to sale; and that on consultation they have determined to offer 12 years' purchase. Whether they will carry out this alleged determination is of course another thing; but I have no doubt that the trustees if dealing direct with the tenants would get a better price.

On the whole case, His Grace decided that I sh[oul]d wire, as I did, to you; and also take Mr Carton QC's opinion, on the whole question, as his opinion will relieve the trustees from all suspicion of acting with any approach to harshness.

His grace will write to you by this post.

Please let me have the copy mortgage - dated, I think, April 1872 - which I returned to you when last in the college. I want it to submit with the case to $\mathrm{Mr}$ Carton.

It remains to say that of course receipt of $£^{1,424}$ arrears due 11 Dec[embe]r 1886 will not complicate matters, but his grace thinks that the $£ 1,000$ now lodged sh[oul]d be the last money received till the opinion has been got.

I remain,

Yours sincerely,

P. A. Chance.

13

Copy extract from opinion of R. P. Carton Q.C., 22 November 1887

$$
\text { MCA, } 109 / 3
$$

Under the terms of these resolutions, I am of opinion that the present plain duty of the solicitor to the trustees is forthwith to present a petition to the Court of the Land Judges for a sale of the mortgaged estates and to prosecute the same with all due diligence. The failure of Lord Granard to pay the interest on the mortgage within the stipulated times has now put the trustees in a position entirely to get rid of the clause in the mortgage deed disabling them from calling in the principal monies until the 11th May 1892 . In my opinion this is a position which the trustees in the interests of the college could not be justified in foregoing, having regard to the present position of the land laws, and the present state of the land market.

If all arrears of interest were now paid up to ist May last, and if Lord Granard and the present trustees of the will of George John Viscount Forbes were to execute a proper deed waiving this disabling clause in the mortgage, and thus leave the trustees of the college unrestricted in their right to realise the security whenever they thought fit, I think the solicitor for the trustees might safely postpone the presentation of the petition for 
sale, until after the next meeting of the trustees provided such postponement were sanctioned by the president of the college and by the archbishop of Dublin.

R. P. Carton

14

P. A Chance to Dr Browne, 15 December 1887

MCA, $109 / 3$

Dear Dr Browne,

I sent down and had Lord Granard's estate looked over, and I am told that the land is of the most miserable description possible. Most of the tenants have paid nothing for $2 \frac{1}{2}$ or 3 years and I am very much afraid you would have great difficulty in inducing the Land Commission to advance a penny upon it.

This does not apply to the County Leitrim estate, which I have not yet examined. I was sorry that I was not in when you called but I am told that you saw Messrs Croziers's letter. From it, it is very evident that Lord Granard is playing a long game, and that he does not intend, if possible, to sign the deed of waiver.

I understand the bishops will meet in January next but I should be very glad if you could arrange to communicate with his grace the archbishop meantime.

I have not yet got the papers connected with this matter, in all I believe your late solicitor has about one thousand documents and I understand he is making out a schedule of these.

Yours Sincerely,

P. A. Chance

I5

Report OfC. Friery on visit to the Drumlish portion of the estate of the Right Hon[ora]ble the earl of Granard [December 1887]

$109 / 3$

On Tuesday and Wednesday the 6 th \& 7 th December 1887 I visited the estate of the earl of Granard situate at Drumlish and surrounding districts. I saw the greater portion of the holdings and a large number of the tenantry. The latter appeared to be in a great state of destitution and the land in my opinion in the district visited by me is so bad that it would be impossible for a person to derive a livelihood from 100 acres without even the payment of any rent.

I append a list of the tenants who I interviewed with particulars of their holdings as supplied me by them.

C. Friery. 


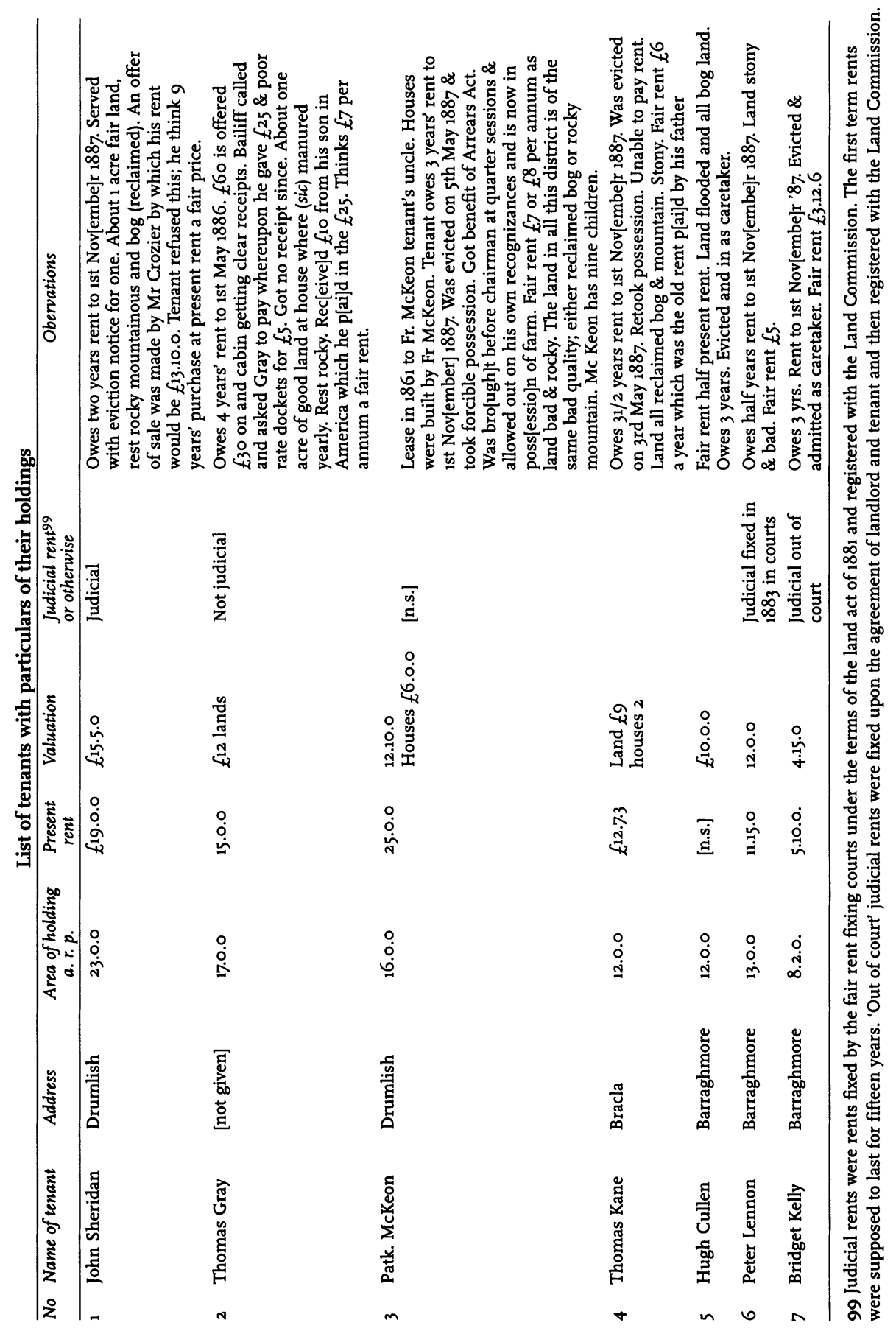




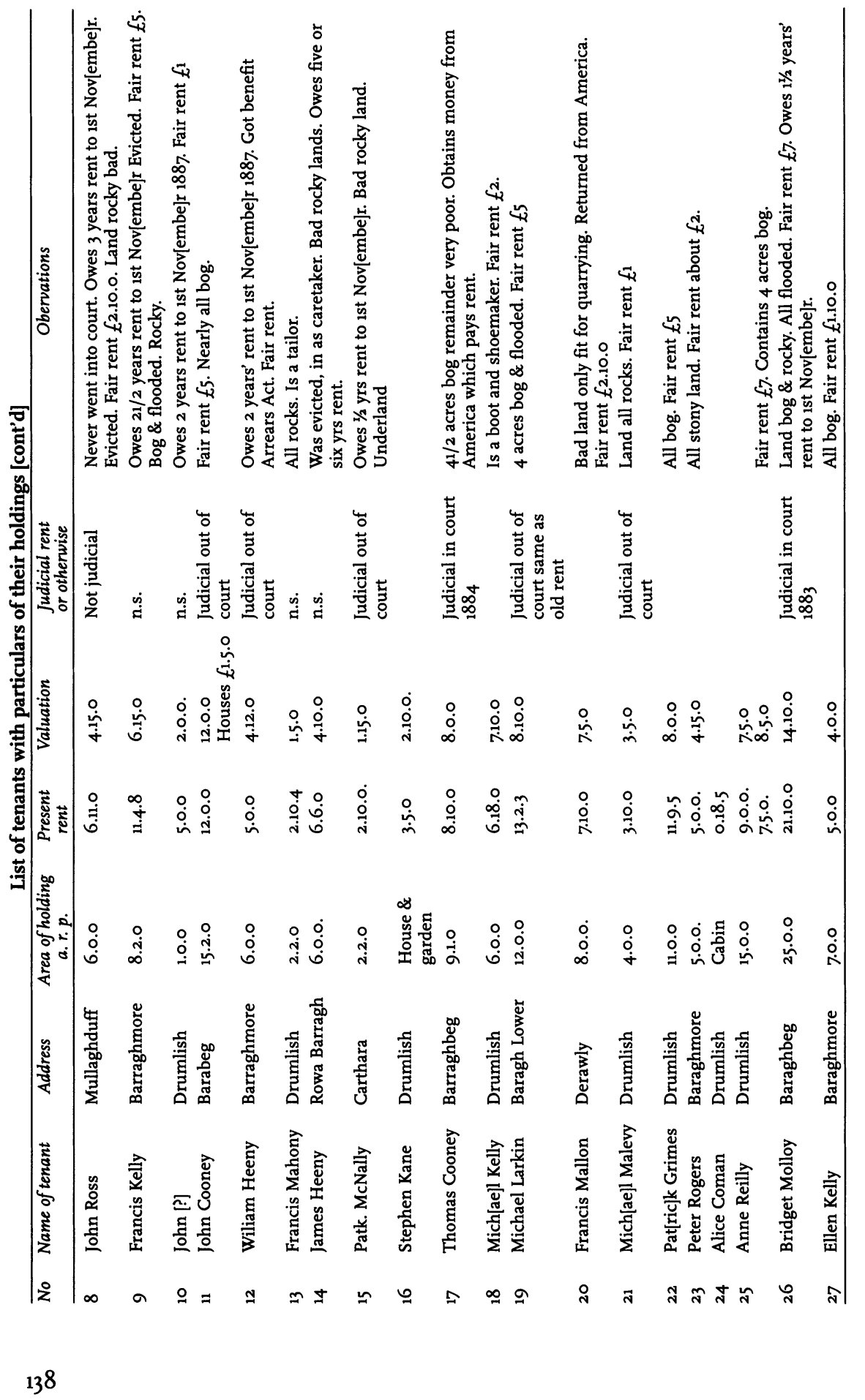




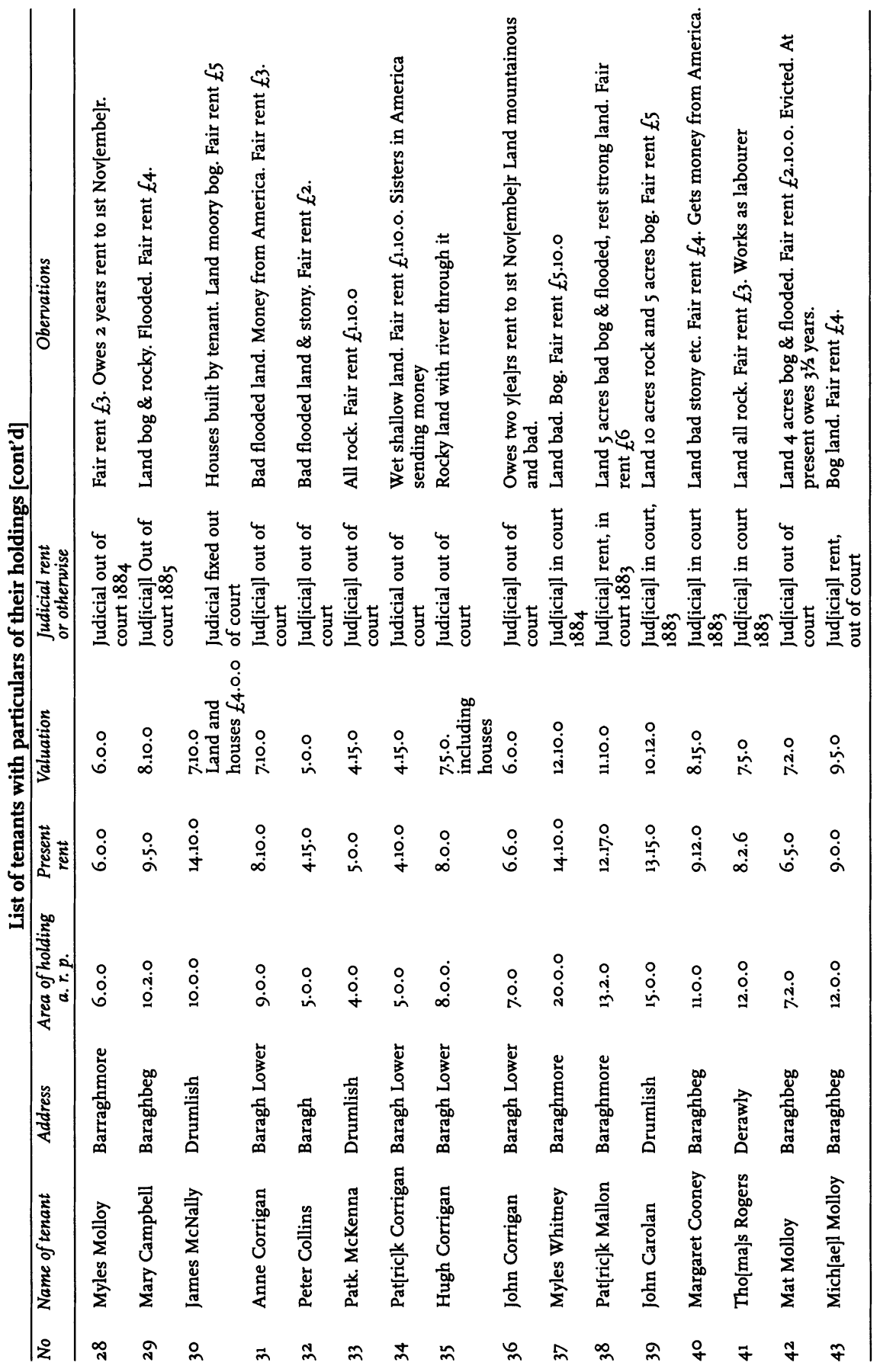




\section{ARCHIVIUM HIBERNICUM}

16

P. A. Chance to Monsignor Lee (Bray), 31 January 1888

$$
109 / 4
$$

\section{Very Rev Dear Sir,}

I find that Lord Granard has taken advantage of our inaction to file a petition to the Landed Estates Court for sale of his estate \& it will therefore be necessary for us to file a cross petition at once in order that we may obtain carriage of proceedings on behalf of the college.

Will you kindly wire whether you can call upon me at 2.30 tomorrow (Wednesday) in order to attach the seal of the college to the petition,

Yours faithfully,

\section{P. A. Chance}

[note appended] Called at $2^{\mathrm{T}} / 2$ 1st Feb[ruary] ' 88 - to attach the seal - the petition was not presented as the keys of the bank boxes could not be had and the [illegible] papers were useless to this purpose.

2nd Feb[ruary] waited in Mr Chance's office from $2 \frac{1}{2}$ until $4 \frac{3}{4}$ while he was repairing the petition - the keys required having been found.

17

Statement by the solicitor of the board of trustees re. mortgages by Lord Granard and his trustees for the trustees of the college of Maynooth, 29 February 1888

$$
\text { MCA, } 109 / 4
$$

By mortgage dated 19th April 1872, Lord Granard and his trustees mortgaged certain lands in counties Leitrim and Longford including the castle and demesne of Castleforbes to the trustees of Maynooth College to secure $£$ 91,592:7:2 with interest at $£$ 4:10:0 per cent reducible to $£$ 4:5:० on punctual payment.

By a second mortgage dated 26 th June 1876 between the same parties

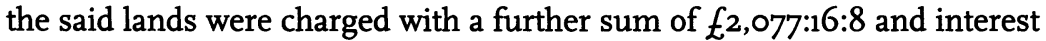
at same rates.

Both these deeds contained a clause prohibiting a sale of the lands before 11 May 1892 provided interest should be paid within sixty days after should become due. Interest was not as paid.

The total annual tenement value of the lands subject to these mortgages is $£ 6,882: 19$ :०. This sum includes $£ 468: 5$ :0 for the demesne and $£ 115$ for the castle of Castleforbes and $£ 306$ for townparks in the village of Newtownforbes. It also includes $£ 790$ value of buildings. Thus deducting the demesne and all buildings on the estate the valu (sic) is $£ 5,509: 13: 0$.

At a meeting of the trustees on 18 th October 1887 the following resolutions were passed 
1. Resolved. That Mr P. A. Chance solicitor be and he is hereby instructed to prosecute a petition or petitions for the sale of the lands of the estate of the earl of Granard and his trustees mortgaged to the trustees of the college of Maynooth.

2. Resolved. That the common seal of the trustees of the college of Maynooth be attached to a petition or petitions to the Land Judges of the High Court of Justice in Ireland Chancery Division for the sale of the lands the estate of the earl of Granard and his trustees mortgaged to the trustees of the College of Maynooth.

3. Resolved. That the secretary of the trustees of the college of Maynooth do (sic) take all steps necessary to prosecute the petitions referred to in the preceding resolution.

Walter M. Lee

Secretary to the trustees.

I believe that in addition to these a further resolution was proposed creating a permanent committee of the trustees to deal with this case.

It was understood that no immediate action should be taken on the resolutions.

On 29th October 1887 His Grace the Archbishop of Dublin informed me that he had seen Lord Granard and that no active step should be taken till January 1888 when he expected there would be a meeting of the trustees.

On 31st October Messrs Darley \& Roe, Lord Granard's agents, wrote to the Rev[eren]d bursar that they had lodged on account of interest $£ 1,000$ to the credit of the college.

On 1st November 1887 his grace the archbishop of Dublin directed the rev[eren]d president to write to Messrs Darley and Roe acknowledging receipt of the $£ 1,000$ and adding that the acceptance was to be without prejudice to the resolution of the trustees. I believe each letter was sent.

I obtained Mr Carton Q.C.'s opinion on the case and he advised that it would be wise to require Lord Granard to sign a waiver of the condition against sale before May 1892 before accepting any further sums on account of interest. See case and opinion sent herewith. On $4^{\text {th }}$ November 1887 I wrote the following letter to Messrs Darley \& Roe.

12 Westmoreland Street, Dublin $4^{\text {th N November } 1887 .}$

Re. mortgages earl of Granard To trustees Maynooth College

Dear Sirs,

The very rev[eren]d president of Maynooth College has handed me a correspondence which he has had with you concerning the interest due on the mortgages.

I have to inform you that the trustees of the College have instructed me to present a petition to the land judges for the sale of the 
mortgaged lands. By direction of his grace the archbishop of Dublin and the very rev[eren]d president of Maynooth I enclose you a copy of the trustees' resolutions and of the opinion of Mr Carton Q.C. as to the duty of the trustees and of me; from which you will gather that unless Lord Granard and the present trustees of the will of the late Viscount Forbes execute a deed waiving the clauses in the mortgages disabling the trustees from calling in the principal monies until May 1892 , neither the president nor I would be justified in delaying to carry out the resolution directing proceedings for a sale nor would the president be justified in accepting any further payment of interest on foot of the mortgages.

Please let me know whether Lord Granard and the trustees of the will of the late Viscount Forbes are prepared to execute the deed indicated in order that the president and his grace the archbishop may consider what course they will in that case pursue,

I am Dear Sirs,

Yours truly,

P. A. Chance

Next day they replied that they had forwarded it to Messrs Crozier, Lord Granard's sol[icito]r And on 6th Dec[embe]r I wrote as follows to Messrs Crozier.

12 Westmoreland Street, Dublin 6th December 1887

\section{Dear Sirs,}

On the $4^{\text {th }}$ November last I wrote to Messrs Darley \& Roe asking whether Lord Granard would execute a waiver of the agreement in his mortgages to the Trustees of Maynooth College not to sell until 1892 .

A few days subsequently I received a letter from you as solicitors from Lord Granard acknowledging the rec[eip]t of my communications but you have not since then informed me whether Lord Granard is or is not willing to execute the proposed deed.

I must ask you to let me have a reply within the next few days.

My instructions as I have already pointed out are imperative and I cannot very much longer delay the presentation of a petition.

Yours faithfully,

\section{P. A. Chance}

Mesrs. Thomas Crozier \& Son,

Sol[icito]rs

19 Lower Dominick Street, Dublin. 
MORTGAGE PAPERS OF ST PATRICK'S COLIEGE, MAYNOOTH, I87I-I923

And on 1oth December 1887 I received from them the following letter

No 19 Lower Dominick Street, Dublin 1oth December 1887

Dear Sir,

We have today seen Lord Granard who is at present in communication with some of his friends in order to arrange for payment of the arrears due to the college and his lordship was informed by His Grace the Archbishop of Dublin that he should have time for this purpose until next month and we presume that your instructions are in accordance with this.

We remain,

Yours faithfully,

Tho[ma]s Crozier \& Son

P. A. Chance Esq. M. P.

12 Westmoreland Street.

On 16th December I received the following:

No 19 Lower Dominick Street,

Dublin, 16th December 1887 .

Dear Sir,

We have heard from Lord Granard and he personally is disposed to waive the clause in the mortgage deed but he has asked us to consult Mr Piers White who is his lordship's sol[icitor]. He is at present on the winter assizes so that he will not have an opportunity of seeing him until his return. Meantime if you will send us the draft of what you wish his lordship to sign we will submit it to him.

Yours faithfully,

Thos Crozier \& Son

P. A. Chance Esq. M. P.

12 Westmoreland Street.

On 2oth December I wrote to the rev[eren]d president the following:

12 Westmoreland Street,

Dublin 2oth December 1887

Re Granard

Dear Dr Browne,

I have received a letter from Lord Granard's sol[icito]rs asking me to submit the draft deed which I propose Lord Granard and his trustees 
should sign and stating that Lord Granard himself is willing to sign it, but that the other parties must be consulted.

For my own part I think that the object of the deed is perfectly simple and that there is no necessity to submit the draft until the parties have made up their minds whether they will sign it or not.

Dean Lee has had the schedules of the Alexander and Granard documents checked in Mr Carraher's office but I understand $\mathrm{Mr}$ Carraher refuses to give up the documents until he is paid some $£_{16}$ for making the schedules.

Dean Lee was at first inclined to pay this but on reflection he made up his mind that it would be better the bill should be presented to the trustees \& p[ai]d in the ordinary manner, consequently I have not got any papers as yet.

I fear that if I do not get the papers until after the trustees have met and paid Mr Carraher's demand I will hardly be in a position to speak very definitely to them. I should like to have your instructions upon these matters.

Yours truly,

P. A. Chance.

I did not feel justified to put the college to the expense of a draft deed until I received assurances that Lord Granard's trustees execute it. I looked upon Messrs Croziers' letter as one written merely for the purpose of delay. I was strengthened in this by the following letter:

No 19 Lower Dominick Street, Dublin, 2oth December 1887.

\section{Lord Granard \\ \& Maynooth College}

\section{Dear Sir,}

We think it well to mention that his lordship informs us that the college has extended the time for his paying up the arrear of interest until February.

Yours truly,

Tho[ma]s Crozier \& Son.

On $4^{\text {th }}$ January $1887 \mathrm{Mr}$ Crozier called on me and stated he was collecting rents to pay the interest and that he assumed that if interest were paid and the deed of waiver signed no proceedings w[oul]d be taken to realise the estate. I replied that the trustees were very anxious not to press Lord Granard but that I feared I could not hold out hopes that the estate would not be ultimately realized and that the whole matter would be considered by the trustees at their next meeting and that probably they would be glad to 
make a compromise of their claim for a lesser sum if Lord Granard would pay it.

On 1oth January $1887 \mathrm{Mr}$ Crozier again called on me and stated that what I had said at the previous interview surprised Lord Granard and he asked me whether the trustees would take $£ 75,000$ for their debt. I told him I was not authorised to make such a statement but thought it probable the trustees would entertain some proposal to arrange the matter. I asked him whether he would cooperate with me to sell some of the poorer lands if I could guarantee him 15 years on the valuation. He referred to the valuation of the lands and stated the rental was greatly in excess of it in some cases, mentioning one townland where the valuation was about $£ 500$ and the rental $£ 9 \circ 0$. He said he would consider the matter and promised to write to me.

I did not receive any further communication from Lord Granard's sol[icito]rs until 3oth January 1888 when the following came.

\author{
No 19 Lower Dominick Street, \\ Lord Granard \\ \& Maynooth College
}

Dear Sir,

Having promised to communicate with you in reference to this business, we think it well to send you a copy of a letter which we have addressed to the president and trust we may count on your support in getting what we and others consider a fair reasonable concession having regard to all the circumstances. Later on we will hope to confer with you as to a sale of the townlands we spoke of.

Yours truly,

Tho[ma]s Crozier \& Son.

\title{
Enclosure
}

No 19 Lower Dominick Street, Dublin, 3oth January 1888 .

Very Rev[erend Sir,

Acting under instructions received from the earl of Granard we have been engaged for some time past in trying to procure a loan to pay the arrear of interest due to the trustees of the college, but owing to the present state of affairs it is almost impossible to borrow money on any landed security in Ireland and we should certainly have failed in our endeavour to do so had not relatives of our client come forward to help him in the present emergency.

His lordship is now prepared to pay over to the trustees a sum of $£ 8,500$ but having regard to the very large abatements which have 
had to be made to the tenants as well as to the non payment by a very considerable number of them of any rent whatever his lordship feels that he is only asking the trustees what is just and fair in proposing that they sh[oul]d accept this sum and give him a clear receipt for all interest up to the last gale day.

From interviews which we have had with Mr Chance the trustees' solicitor, we have been given to understand that even if the interest question were settled the trustees would not be satisfied to let their principal money remain outstanding without some effort being made towards realising the amount by sale and his lordship has been therefore advised by co[unse]l that if a sale be unavoidable the necessary proceedings could be far more effectively and economically carried out at his instance than at that of any creditor or third party. We fully concur in the prudence of that advice and we have therefore presented a petition to the Landed Estates Court for a sale.

Mr Chance was good enough to say that he would facilitate his lordship in a sale if any of the townlands wish to sell to the tenants and his lordship will be glad to avail himself of any assistance that the college may direct Mr Chance to afford.

His lordship however feels convinced that the present time is a most inopportune one for forcing and pressing a sale and hopes the trustees will concur with him in so conducting any future proceedings as shall best promote the common interest and secure in the present emergency the fair value of the security held by the trustees.

We are very rev[eren]d sir,

Your obedient serv[an]t,

Tho[ma]s Crozier and Son.

I replied by merely acknowledging receipt. There was then $£ 4,471: 9: 6$ due for interest.

The rev[eren]d president to whom the above letter was addressed also acknowledged receipt, and stated would lay the matter before the trustees.

On 2nd January 1888 I lodged a petition on behalf of the trustees praying a sale of the estate. I did so because otherwise Lord Granard had taken the first step towards a sale and he would otherwise have obtained carriage of the proceedings and consequently retained a larger share of the management of the estate than if I had carriage.

In addition to this his solicitor might delay making absolute the conditional order for sale until it would be too late to move for the appointment of a receiver to capture the rent falling due 25 th March 1888 . I assumed that these rents if collected by Lord Granard might be lost to the Trustees. Lord Granard's sol[icito]r took no steps to proceed on their petition until after I had served on Lord Granard a conditional order for sale on foot of the trustees' petition. 
MORTGAGE PAPERS OF ST PATRICK'S COLLEGE, MAYNOOTH, I87I-I923

On 1 February 1888 I addressed to the four archbishops the following letter. In that written to His Grace the Archbishop of Dublin there were some unimportant differences.

12 Westmoreland Street,

Dublin ist February 1888.

My Lord,

Your Grace will recollect that at the last meeting of the trustees of Maynooth College it was directed that I should present a petition for sale of Lord Granard's estate to realise the $£ 96,000$ due to the college.

I think it was understood that this direction was not to be acted on immediately but that the trustees at a subsequent meeting would consider what should be done.

I understand Lord Granard was unable to pay all the arrears of interest. He however paid $£ 1,000$ and then with the privity of his grace the archbishop of Dublin I wrote to his solicitors informing them that as the trustees would require them to waive the agreement not to realise the mortgage until 1892 interest being meanwhile punctually paid before they could safely accept further payments on account of arrears of interest.

Lord Granard has not signed such deed of waiver. His solicitor informed me that they should consult the other parties interested. On Monday last Lord Granard filed in the Landed Estates Court a petition on his own behalf praying a sale of the lands and one (sic) same day his solicitor wrote to the rev[erend] president of the College a letter asking him to accept $£ 3,500$ for arrears on interest ( $£ 4,470$ now due) and stating that he understood from me that it was probable the trustees would not feel justified in allowing matters to rest and that consequently he proposed to have the estates sold in the Landed Estates Court.

I have to point out to Your Grace that as a consequence of this $\mathrm{Mr}$ Crozier, Lord Granard's solicitor, will have carriage and that consequently his costs will come out of the proceeds of the sale thus increasing the deficiency which I fear will result. He will also be in a stronger position to deal with the tenants than if he had not carriage.

From a paragraph in Mr Crozier's letter it appears he is not anxious to carry the matter through the court with any great expedition.

Under these circumstances and acting on the authority of the resolutions I refer to I have prepared a cross petition which I hope to file tomorrow.

I should like to have your graces' instructions as to this. For myself no course other than that I indicate appears open to the trustees.

I received the following replies. 


\section{Dear Sir,}

In reply to your letter of yesterday's date I beg to say that my recollection of the arrangement made at the last meeting of the trustees of Maynooth College was the following:

The trustees virtually decided that steps should be taken to bring the estate of Lord Granard into the court for sale as there seemed to be no reasonable prospect of his lordship being able to meet the arrears of interest due on the mortgage.

The trustees however wishing to give his lordship every chance and facility of meeting his engagements consistent with the interests of the college decided that their resolution should not be acted upon at once. Hence it was arranged that on some day before the ist January 1888 a meeting of the visitors should be held to instruct you to proceed with the legal steps necessary if in the meantime Lord Granard had not paid at least such portion of the arrears as the visitors considered satisfactory. It was decided however that in the event of Lord Granard complying with this condition legal proceedings should not be stayed beyond the ist Jan[uar]y 1888 .

No meeting of visitors was held owing probably to the absence of the archbishop of Dublin and the president. Hence as Lord Granard has not paid a portion of the arrears which could be regarded as at all satisfactory I believe the original resolution of the trustees should be carried out and that you are sufficiently authorised by it to take such legal proceedings as you consider necessary to safe guard the interests of the college.

Of course beyond this expression of opinion I as an individual visitor have no power to instruct you as to the action you should take but I am quite sure you can take for granted the sanction of the visitors and of the trustees also for any steps you consider necessary to keep the interests of the college safe.

It is likely that after the return of the president a meeting will be called to consider the matter carefully but in the meantime I think you should let no step be taken on the part of Lord Granard's solicitor which would prejudice the chance of the college to save as much as possible from the wreck.

I am Dear Sir,

Yours faithfully,

Michael Logue.

Mr Justice Monroe at first refused to direct a sale on the trustees' petition on the grounds that Lord Granard had already filed a petition but on point- 
ing out that Lord Granard's petition did not enable a sale of the castle and demesne Mr Justice Monroe finally fiated the petition of the trustees.

I am now in a position to have an absolute order for sale made on the trustees' petition before Lord Granard can on his.

P. A. Chance

12 Westmoreland St.

$29 / 2 / 88$.

18

Copy letter Messrs Crozier to the President of Maynooth, 30 January 1888

MCA, $110 / 16$

\section{Dear Rev Sir,}

Acting under instructions received from the earl of Granard we have been engaged for sometime past in trying to procure a loan to pay the arrear of interest due to the trustees of the college, but owing to the present state of affairs it is almost impossible to borrow money in any landed security in Ireland, and we should certainly have failed in our endeavour to do so had not relatives of our client come forward to help him in the present emergency.

His lordship is now prepared to pay over to the trustees a sum of $£ 3,500$, but having regard to the very large abatements which have had to be made to the tenants as well as to the non-payment by a very considerable number of them, of any rent whatever, his lordship feels that he is only asking the trustees what is just and fair in proposing that they should accept this sum and give him a clear receipt for all interest up to the last gale day. ${ }^{100}$

From interviews which we have had with Mr Chance, the trustees' solicitor, we have been given to understand that even if the interest question were settled the trustees would not be satisfied to let their principal money remain outstanding without some effort being made towards realizing the amount by sale and his lordship has been therefore advised by counsel that if a sale be unavoidable the necessary proceedings could be far more effectively and economically carried out at his instance than at that of any creditor or third party. We fully concur in the prudence of that advice and we have therefore presented a petition to the Landed Estates Court for a sale. Mr Chance was good enough to say that he would facilitate his lordship in a sale of any townlands he might wish to sell to the tenants, and his lordship will be glad to avail himself of any assistance that the college may direct Mr Chance to afford. His lordship however feels convinced that the present time is a most inopportune one for forcing or pressing a sale and hopes the trustees will concur with him in so conducting any future 


\section{ARCHIVIUM HIBERNICUM}

proceedings as shall best promote their common interest and secure in the present emergency the fair value of the security held by the trustees.

We are very rev[erend] sir,

Your obedient servants,

Tho[ma]s Crozier \& Son.

19

\section{P. A. Chance to Browne, 13 April 1888}

$\mathrm{MCA}, 109 / 4$

Dear Dr Browne,

I have received information that Lord Granard has served a large number of writs upon his tenants and is generally engaged in carrying on war. I assume his object is to raise enough to pay the arrears of interest, and thus avoid the appointment of a receiver, and evade the jurisdiction to refuse rents and remit arrears which the court would have if a receiver were appointed.

Yours very truly,

P. A. Chance

20

P. A. Chance to Dr Browne, 18 April 1888

MCA, $109 / 4$

Granard Estate

Dear Dr Browne,

It seems the guard refused to take the letter I sent you at 4 o'c yesterday \& so it has miscarried. Mr Crozier, Darley \& Lord Granard have filed affidavits $\&$ will move on Monday for carriage. I have just got copies of their affidavits $\&$ it is most important to answer them.

They state that the security is ample without having recourse to the demesne, that the tenants will pay no one but Lord Granard, with whom their relations are almost paternal, that no one but Mr Crozier knows anything about the title, ditto Mr Darley about the tenants, they dispute the amount of interest due, set out the whole correspondence between His Grace the Archbishop of Dublin \& Lord Granard and a letter dated 12 March written to Dr Gillooly, ${ }^{101}$ and also allege that I promised not to sell the castle $\&$ demesne \& not to appoint a receiver, which is absolutely untrue.

Ior Gillooly was a Vincentian and one of Archbishop Paul Cullen's most trusted allies. He was bishop of Elphin $1856-95$. 
MORTGAGE PAPERS OF ST PATRICK'S COLLEGE, MAYNOOTH, I87I-I923

The whole proceeding shows the danger of attempting to soften the fall of a man in Lord Granard's position.

I have drawn a long affidavit in reply which I will try \& have settled by Mr Carton this evening.

It will be most necessary for you and Fr Donnellan to make affidavits in reply. They will not however be very long.

Could you not manage to come to town tomorrow \& do so?

I have just now ( $5 \mathrm{pm}$ ) received a note from Mr O'Brien asking me to defend him tomorrow. I will however leave the fullest instructions for your affidavits after having Mr Carton's advice thereon.

Yours truly,

P. A. Chance.

$2 I$

P. A. Chance to Dr Browne, 20 April 1888

MCA, $109 / 4$

Dear Dr Browne,

I hope that you and Fr Donnellan will be up [to Dublin] early on tomorrow as your affidavit and Fr Donnellan's must both be sworn and filed before one o'clock. I know how troublesome it is for you to keep running up to town so often about this business but it really cannot be helped and I trust we are at the end of the fight,

Mr Carton settled my affidavit by striking out of it a great deal of the matter relating to $\mathrm{Mr}$ Crozier, as he thought it irrelevant. He says that in his opinion this gentleman has acted very badly in taking advantage of the indulgence which the college showed him and he does not think there will be much difficulty in pulling the case through.

Yours truly,

P. A. Chance

22

Chance to Browne, 23 April 1888

$\mathrm{MCA}, 109 / 4$

Dear Dr Browne,

Granard's estate was before Judge Monroe, but he will not give his decision until Wednesday. It came out, in the course of proceedings, that Lord Granard received out of the estate net rent May ' 83 to ' $84 £ 9518$, May ' 84 to '85 $£ 9,526$, May ' 85 to June $86 £ 7,922$, June ' 86 to December 87 (sic) $£ 7,187$. So that, so far from there being any truth in the statement that the tenants were not paying, they have in those four years and a half paid far more than the yearly valuation. 
It seems that the rents were applied to pay the interest on the subsequent mortgages and that that is the secret of their support of Lord Granard.

Dr Gilooley's (sic) letter to Lord Granard, ${ }^{102}$ written after the meeting of the visitors, was read in court, and had certainly a most injurious effect. It states virtually the whole of the proceedings of the visitors, and amongst other things that, as to Lord and Lady Granard's complaints against me, 'I satisfied the bishops, or at least made such statements, as they were unable to contradict'. I need not point out to you how unjust this is to me.

I have got an order from the court for a copy of this correspondence, and as soon as I receive it, I will let you have it.

As things stand, I am afraid, as a result of Dr Gilhooly's (sic) action, not only will a receiver be refused to the trustees, but Lord Granard will obtain carriage of the whole proceedings.

Yours truly,

P. A. Chance

23

P. A. Chance to Dr Browne, 25 April 1888

$$
\text { MCA, } 109 / 4
$$

Private

Dear Dr Browne,

I went to court this morning and saw Mr Carton. He advised me not as yet to make any formal application to Judge Monroe for Dr Gillooley's (sic) letters as it would tend to shew strained relations between us, At the same time he said there was no doubt we were entitled to \& he would certainly secure the copies.

I then went to Mr Manning, Judge Monroe's chief clerk, and he told me that the original letters were actually with the judge; \& he took from me Messrs Crozier's letter refusing copies without counsel's advise \& promised to speak quietly to the judge about the matter.

It is very curious to note that while with Dr Gillooly \& the Visitors the case was made that my action compelled Lord Granard to proceed, the case made in court is that I virtually committed a breach of faith on proceeding at all; and through Dr Gillooley's (sic) letters my defence to the former charge is made a proof of the latter. You will recollect that I anticipated the use of Dr Gillooly's letters in court. Their use is the best evidence of the hopeless position of Lord Granard's case without them, as I cannot otherwise account for what Dr Gillooley's (sic) letter to you shews to be a gross breach of his confidence. 
I regret extremely the position of affairs with regard to Dr Gillooly. It is very hard to have our hand exposed to the enemy; \& when discussing the case with the bishops I thought I was justified in dealing with them as my clients, and speaking unreservedly. In Dr Gillooly's letter written before the meeting he says he received a letter from you stating (as is the fact) that my proceedings were taken in self-protection, \& that if Crozier's course were not checked the college would not have the means of enforcing payment of interest from the rents. This drew from Lord Granard the very clever (\& advised) letter offering a receiver by deed. You will recollect that I pointed out that a receiver by deed would be wholly in the hands of Lord Granard \& $\mathrm{w}$ [oul]d not without his consent be able to make remissions to the tenants, $\&$ that all evictions etc. by him would probably be publicly ascribed to the college. Of course those reasons could not be alleged before the judge; and as Lord Granard's offer of a receiver by deed (which was the direct consequence of Dr Gillooly's letter disclosing our hand) has been used against us by Judge Monroe who asked Mr Carton 'whether a receiver appointed by deed \& bound to apply the rents to keep down our interest would not give the college all the security they had a right to'. Of course my recollection of what took place on 13 March is identical with yours.

(Later) I have just come back from court to which I was called by a letter from Mr Manning. I got \& enclose a copy of one of Dr Gillooly's letters. The second one though read in court and noted by the judge was not forthcoming. Judge Monroe on discovering this, directed me to write calling for the lodgement of the letter \& a copy for myself; and adjourned judgment in the case till Monday.

It is almost unprecedented for carriage to be taken from a substantial incumbrancer but I fear it will be done; because it is equally unprecedented for one's client to play into the opponent's hand \& the trustees cannot expect me to do their business with any degree of success, if every move \& consultation is reported to the enemy.

I recollect that in Dr Gillooly's second letter he puts the failure of the trustees to stop me on the ground that there was not a quorum of them present on 13 March.

The Freeman people are quite willing to write any article I dictate: in fact they have asked me to write it myself. I think it would be wisest for you to have a conference with Mr Ennis their leader writer on Monday \& settle what the leader is to be. I must leave for London on Monday evening on law business for a few days.

I enclose you a copy of two letters which may be useful.

I fear Dr Gillooly is in an awkward position - either Lord Granard or he is mistaken as to the confidential character of their letters; and in any case he communicated our tactics to the other side. The tenants will I fear suffer for it all. 
We must recollect that even if the estate is sold to the tenants for $£ 120,000,1 / 5^{\text {th }}$ of this must be retained as a guarantee deposit, ${ }^{103}$ and so there w[oul]d even at this too sanguine estimate be barely sufficient to pay the college.

[Remainder of this document seems to be missing].

24

Copy judgement delivered by Mr Justice Monroe in regard Lord Granard, the 27th day of April 1888, in the High Court of Justice in Ireland, Chancery Division, Land Judges

$$
\text { MCA, 109/4 }
$$

This case comes before me on two motions one instituted by the trustees of the College of Maynooth for the appointment of a receiver, and the other by the owner, Lord Granard, for the consolidation of certain pending petitions for sale and for carriage of the proceedings. The motions are important to the parties and it is right I should state the material facts set out in the several affidavits. The earl of Granard is possessed as tenant for life of considerable estates in the Counties of Longford and Leitrim the gross annual rental of which appears to be $£ 7,968$. They are subject to several charges some affecting the fee and others the life estate. There is due to the trustees of Maynooth College who are the first incumbrancers on the fee the sum of $£ 93,670$ for principal, the other incumbrances on the fee amounting to about $£ 20,000$ are charges for younger children besides $£ 1,000$ a year for Lady Granard's jointure. The charges on the life estate amount to $£ 8,535$. The annual interest in the charge of the trustees of Maynooth College amounts to $£ 3,980$ and in the month of October 1887 there were arrears of interest due thereon amounting to $£ 3,480$. The trustees were dissatisfied with the state of things and on the 18 th October 1887 they passed a resolution at their half-yearly meeting that proceedings for sale should be commenced in the Landed Estates Court. The terms of the resolution were on the same day communicated to Lord Granard by Archbishop Walsh one of the trustees who however wrote that the proceedings would be suspended if satisfactory arrangement were made before the ist of January. Lord Granard in reply said he hoped to make a remittance on account of interest before November. On the 31st October a sum of $£ 1,000$ was paid. Mr Chance the solicitor for the trustees wrote on the $4^{\text {th }}$ November to Lord Granard's agents informing them that he had been instructed to file a petition for sale which he should do at once unless Lord Granard consented to execute a deed waiving a clause in their mortgage preventing them in the event of interest not being punctually paid, from calling in their mortgage debt before the year 1892. Lord Granard then saw Archbishop Walsh who undertook the responsibility of directing the solicitor not to act immediately on

I03 Under the land act of 1885 one fifth of the purchase money to be advanced to the landlord in cash was retained by the Land Commission as a guarantee deposit to make good any defaults in the payment of annuities by purchasers. 
the resolution of the trustees, and this he confirmed by a letter on the 9th of November. On the 11th November another half year's interest became due the arrears then amounting after payment of the $£ 1,000$ to $£ 4,470$. Lord Granard's solicitors were raising a loan to pay off the arrears but he had asked that some abatement should be made in the amount as he had himself been obliged to give considerable abatements in the rents. Mr Crozier, solicitor for Lord Granard, wrote to Mr Chance on the 1oth December, telling him he was getting the money, and on the 13th December Mr Chance replied that he would take no immediate steps owing to a communication he had had from the archbishop but asking a definite rely as to waiver. On this Mr Crozier said he wished to consult counsel who was then at the winter assizes and he asked for a draft deed of waiver, which was however never sent. On the $4^{\text {th }}$ January Mr Crozier had an interview with Mr Chance. There is some difference between them as to the details of the conversation but nothing very substantial. They spoke about the appointment of a receiver. Mr Crozier said if a receiver were appointed no rent would be collected. According to Mr Crozier's version Mr Chance said that he did not think the trustees would ask for a receiver and further that they would not think of disturbing Lord Granard in the possession of the house and demesne of Castleforbes. $\mathrm{Mr}$ Chance alleges that all he stated was that the Trustees would not ask to appoint a receiver unless absolutely necessary and that they would not willingly sell the castle and demesne, but that being trustees they could not bind themselves to anything. They should act in the best interests of their college. He further stated that the lands he believed should be sold and that in his opinion their sale would not realise sufficient to pay his client's charge. The necessity for having the lands sold was further communicated by $\mathrm{Mr}$ Chance to $\mathrm{Mr}$ Crozier in an interview on the 1oth January 1888 and there was some discussion as to the trustees abating a portion of their demand. Mr Crozier then consulted counsel who advised him that if a sale must take place the lands could be sold to far greater advantage if Lord Granard had himself the control of the proceedings. A petition was accordingly filed by Lord Granard on the 3oth January for sale of all the lands save the castle and demesne and in a letter of that date to the president of the college copy of which was sent to Mr Chance - the reasons for taking this course were fully explained. The letter further stated that Lord Granard was prepared to pay over to the trustees a sum of $£ 3,500$ on account of arrears of interest and expressed a hope that this sum would be accepted in full discharge up to the last gale day. Lord Granard alleges that the castle and demesne were omitted solely on account of the interview with $\mathrm{Mr}$ Chance on the $4^{\text {th }}$ January and in the belief that the sale of the remainder would be quite sufficient to pay off the charges. There was some delay about getting the title of a fee farm grant under which one of the denominations was held which necessitated an amendment in the petition so that the conditional order for sale was not made till the 2oth February. In the meantime a petition for sale was presented on the 2 nd February by the trustees of Maynooth for sale of the entire lands including the castle and demesne. Owing to the omission of these from the first I was obliged to fiat the second petition. Lord 
Granard subsequently filed a supplementary petition for sale of the house and demesne and lodged $£ 3,500$ to the credit of the trustees asking for a favourable consideration of his previous request. The conditional order on the trustees' petition was made absolute on the 24th March; that on the owner's petition on the 12th April, some correspondence took place between Lord Granard and Dr Gillooly, the Bishop of Elphin, one of the trustees, about the pending proceedings, before either of the conditional orders had been made absolute. In a letter to Lord Granard of the 5th of March 1888, the bishop stated that he was informed the petition of the trustees had been filed in self-defence, and because if the owner's proceedings were not checked the payment of the trustees' interest could not be enforced. To that letter Lord Granard replied on the 12th March denying that his proceedings could have any such effect, expressing his readiness to file the supplemental petition, which he subsequently did, for sale of the castle and demesne, and offering, if the trustees so desired, to appoint a private agent over the estates to pay the interest or charges according to the priorities. The bishop replied to this letter on the 14th stating that the trustees were advised that they were bound to file a petition and seek to have a receiver appointed, but once the affidavit was made no further action would be taken till the trustees met in June. No answer has yet been given to Lord Granard as to whether the trustees will insist on the full amount of arrears so that after giving credit for $£ 3,500$ lodged, there remains about $£ 9 \circ 0$ still due for interest up to the last gale day. The trustees now ask to have an official receiver appointed over the estate, and the first question is are they entitled to succeed in this application? The circumstances under which a receiver may be appointed are I think correctly laid down in the Herbert v Green (3 Ir Ch 270). 1. When a year's interest is due on the incumbrance. 2. When the property is in danger from eviction or otherwise. 3. When there is reason to apprehend that the proceeds of the sale will be insufficient to pay the charges. In this case there is not a year's interest due; in fact Lord Granard has expressed his readiness to pay up the amount now due at anytime the trustees require him to do so. There are practically no head rents so that the case of the trustees entirely rests on the contention that the estate is an insufficient security. There is an expression of opinion by the president, the secretary and the bursar of the college, and by $\mathrm{Mr}$ Chance, that the proceeds of the sale will be insufficient to meet the charges of the trustees. There is an equally strong expression of opinion by Lord Granard, Mr Crozier and Mr Darley that the estate is ample security. I cannot reconcile their conflicting opinions, and I must, therefore, take the figures as I find them, or form a judgement for myself. To justify the appointment of receiver on this ground, the insufficiency of the security to meet the trustees' charges should be very clearly shown, since if the application were carried out to its logical consequences I should impound or pay all the rents, after payment of interest to the trustees on foot of their principal and not pay interest to the puisne incumbrancers at all. I can find no trace of a receiver having been appointed in this court where all interest had been paid, on the ground that the security was insufficient. The gross rental of these estates is $£ 7,963$. The government 
valuation is $£ 6,882$. Eighteen years of the former would give $£ 133,334$; eighteen years' purchase of the government valuation would give $£^{123}, 876$. Less than 12 years' purchase of the rent and less than 14 years' purchase of the government valuation would suffice to pay off the full amount of the trustees' claim. Nor is there a mere rental on paper. I have it from the agents' books that in the four years and a half which elapsed from the 1st May1884 to the 1st December 1887, no less than $£ 8,000$ a year was collected, being more than one full year's rent each year. $\mathrm{Mr}$ Carton for the trustees for the trustees fully admitted that no rent collector could possibly have been better. He complained that with such a collection his clients' interests should not have been more punctually paid and Lord Granard meets the objection by offering to appoint a receiver under deed. The rule, therefore, I make on the trustees' application is this: Lord Granard by his counsel undertaking within one month from this date to execute a deed appointing Messrs Darley and Roe his agents to collect the rents of the estates comprised in the petitions for sale, and to pay the interest to the incumbrancers according to their priorities, I refuse the motion to appoint a receiver. I should be taking a course disastrous to the interests of the trustees of Maynooth College, and all the creditors unanimously oppose the motion. The owner's cross notice asks for a consolidation of the several petitions and for an order that he may have the carriage. The matter of consolidation is a matter of course so that the only question is as to the carriage of proceedings. I have already mentioned how the several petitions came to be filed and subsequently fiated. The owner filed his petition first. The trustees were the first to obtain their absolute order for sale. The motion before me is not to take the carriage from one and give it to another. There are two or rather three petitions with separate absolute orders. These are now to be consolidated. Who is to have carriage of the consolidated orders? I am bound to state that throughout these proceedings the trustees have shown no hostility to Lord Granard. The letters of the archbishop and the bishop of Elphin clearly indicate that consistently, that with the due execution of their trust they are willing to adopt any course which may be deemed conducive to the interests of Lord Granard and his family. In opposing this motion they are acting with the most perfect bona fides. Mr Carton rested his case on three grounds. (1) That according to the practice of this court carriage of proceedings will never be given to an owner who is in default in the payment of interest. (2) That the estate is not sufficient to pay the trustees' charges and (3) that the trustees are most likely to bring the property to a speedy and effective sale. In support of his first contention he relied on the case of in re[gard] Tottenham (7 Ir [illegible]) where an owner sought to take the carriage of proceedings from an incumbrancer to whom over ten years' interest was due. The court declined to transfer the carriage where such large arrears were due, and that cases (sic) was probably well decided on its facts; but I am not prepared to accept any hard and fast rule by which an owner, when any interest is due, is to be prevented from having the carriage when every other consideration is in his favour. In this case only three months' interest is due up to the last gale day, and that has been withheld only pending Lord Granard's request 
for an abatement in the percentage. If the trustees say that they are not at liberty to grant any abatements he has expressed his readiness to pay up the balance. I have already dealt with the second point made by Mr Carton. In my opinion on the figures before me, Lord Granard, if not for himself, at least for Lady Granard and his younger children, has a substantial interest in the estate. The only remaining consideration is which of the parties is most likely to carry on the proceedings in the interest of all the creditors and of the owner of the estate. The parties seem to be agreed that if this property is to be sold, it is most likely to be sold to the tenants under Lord Ashbourne's act. This will to some extent involve the settlement of rights of way and other easements and of many other questions which would not arise if the estates were sold in one or several large lots in the ordinary way by public auction. Well in the first place the owner's petition is presented by Mr Crozier one of the members of a firm who have managed the estates for the last fifty years. He himself was acting as land agent down to the year 1883 when he resigned and Messrs Darley and Roe were appointed to succeed him. He is still the law agent of the estate. He is familiar with the title. He knows every holding, and almost every tenant on the property and on every disputed question his assistance would be invaluable. Again Lord Granard has been living all his life among his tenantry. When differences have arisen, the tenants, he says, have freely sought his aid in settling them. He, too, is thoroughly acquainted with every holding on his estate, and he alleges that he and his tenants in the absence of what he calls external influence have always been on the most friendly terms. A remarkable instance of this is shown in the fact that all the tenants on one denomination have offered to purchase their holdings at prices to be fixed by the landlord or his agents. Both Lord Granard and Mr Crozier expressed the opinion that the estates will be sold to far better advantage if the negotiations which have already begun before the resolution of the trustees was passed are left to be conducted by them. On the other hand, the petition of the trustees alleges that they have no means of knowing the easements and other rights affecting the premises, and that they have no means of knowing, and do not know whether any of the premises for sale are subject to any leases, tenancies, or rents. I fail to see how the trustees could under these circumstances effectively carry out a sale to tenants where intimate knowledge of the different holdings would probably be essential. There is another matter which has weighed with me in coming to the conclusion at which I have arrived. The trustees through their responsible officers and the solicitor having carriage of their petition have expressed their opinion that the property will not and cannot realise within some thousands of pounds of a sum sufficient to pay the trustees' charge; in other words that this property cannot realise more than twelve or thirteen years' purchase of the government valuation. If the tenants made proposals based on these opinions the trustees would find it very difficult to reject them or to refuse to put them forward for acceptance. The court might then be placed in the difficult position of either accepting offers which were deemed to be insufficient or of discrediting the action of those who were responsible for the carriage of the 
proceedings. On the whole I have arrived at the conclusion that Lord Granard or his family have a substantial interest in these estates. That Lord Granard and his solicitor have such an intimate knowledge of the property and of those most likely to become the purchasers as will enable them to dispose of it to the best advantage, and that it will be for the interest of all including the trustees that the carriage of the consolidated proceedings should be given to the owner. Should there be any unnecessary delay, the remedy is easy as rapid. I may add that the view I have taken is shared by every incumbrancer on the estate puisne to the trustees. I allow the trustees their costs of filing their petition and of this motion with their demand. The owner is entitled to his costs as costs in this matter.

\section{5}

Messrs Crozier to Dr Browne, 22 June 1888

$$
\text { MCA, } 110 / 16
$$

\section{Very Reverend Sir,}

As we understand that the trustees of the college are about to hold their usual meeting we have been requested by Lord Granard to recall to your recollection the application which we at his lordship's instance made to you in the early part of the present year for some abatement in the interest which was at that time due, and in respect of which payments have been since made. We would at the same time ask you to kindly bring before the board the question of a permanent reduction in the rate of interest until the mortgage is realised.

We may add that since the application was made Lord Granard has been obliged to give to the tenants, in addition to the usual judicial reductions, those prescribed by the last act of parliament, which of course has had the effect of still further diminishing the means of meeting the annual interest.

Messrs Darley \& Roe have now been appointed receiver under deed which strictly recognises the first charge of the college on all the rents and directs them to pay accordingly. They are doing their utmost to get in the rents and we trust that with a good harvest, which at present there appears to be a fair prospect of, the tenants will be able to meet their obligations.

We think it right to mention that we applied to the land commissioners to ascertain if they had any money available to enable the tenants the purchase under Lord Ashbourne's act and we received a reply that the fund had been exhausted. As however there seems to be a reasonable prospect of government advancing a further sum we have been making arrangements to offer the holdings to the tenants and we trust that they will agree to purchase on terms equitable to all parties.

We have the honor to be

Very rev[erend] sir,

Your obed[ien]t serv[an]ts,

Thos Crozier \& Son. 


\section{ARCHIVIUM HIBERNICUM}

\section{6}

Memo by P. A. Chance regarding Granard estate, 25 June 1888

$$
\text { MCA, } 109 / 4
$$

The proceedings for sale are still pending. Some of the land is very bad indeed. Lord Granard is so heavily involved that a sale of his estate would not produce sufficient to discharge his liabilities. He has, therefore, no interest whatsoever in expediting a sale. The amount available for purchase by tenants under Lord Ashbourne's act is a prospective two millions. ${ }^{104} \mathrm{I}$ am informed that already applications for loans have been sanctioned to the extent of nearly one million, to be obtained out of the prospective two millions. It is very generally believed that when this money is spent, no further sums will be advanced on the same terms (ie $31 / 8$ th per cent interest). And that, as purchasing tenants fix the price they give altogether by reference to the annual instalment payable, smaller prices will be given for land.

The course of management of this estate up to the present has been unfavourable to the tenants. In my opinion the owner has injured the value of the fee by his efforts to keep down the charges on his life estate. I fear the tenants \& their holdings will yearly become more impoverished, and less likely to secure the Land Commissioners sanction for a large advance to them.

For all the above reasons I strongly recommend the board to authorise me to take strong steps to secure a rapid sale to the tenants on the poorer part of this estate.

27

Further statement of P. A. Chance to board of trustees Maynooth College regarding Granard estate [26 June 1888]

$$
\text { MCA, } 109 / 4
$$

In my last report I stated I was in a position to make conditional order on the trustees' petition absolute, which I accordingly did on the 24th March.

I attended a meeting of the visitors at Maynooth on the 13th day of March 1888 at which Dr Gillooly read to the visitors some statements made by Lord Granard with reference to the proceedings then pending. I advised the visitors that it would be wise to so conduct the proceedings as to ensure carriage to them and that the appointment of a receiver under the court would enable settlements to be made with tenants and so obviate a repetition of the evictions which had taken place the previous year and with reference to the proposal which Dr Gillooly informed the visitors had been

104 Under the terms of the Ashbourne act, almost $£^{10}$ million was in fact advanced to purchasers between 1885 and 1891 , allowing over 25,300 tenants to purchase their holdings; Dooley, Decline of the big house, p. 105. 
made to him on behalf of Lord Granard to appoint a receiver out of court. I pointed out that such receiver would have no power to make reductions or remit arrears of rent without Lord Granard's consent and in answer to Rev[eren]d president I informed the visitors that if the order for sale were made absolute and the carriage retained by me further proceedings could be stayed for practically an indefinite period.

The board of visitors ultimately decided they could not accede to Lord Granard's proposal made through the lord bishop of Elphin to let the proceedings stand until the trustees met as that would involve a loss of the position their petition then had, and the visitors adjourned without coming to any formal resolution.

Before separating, the visitors instructed me to proceed to appoint a court receiver.

On the 1oth day of April I served notice of motion for the appointment of a receiver.

On the 17th April I received from Messrs Crozier notice of motion for 23rd April to consolidate pet[itio]ns and give them carriage.

On the 23rd April the foregoing motions came on for hearing.

In the course of the arguments it was stated by Lord Granard's counsel that Lord Granard received out of the estate net rent 1883 to ' $84 £ 9518$, May ' 84 to ' $85 £ 9526$, May ' 85 to June ' $86 £ 7922$, June 86 (sic) to December $1887 £ 7187$ showing that there was no truth in the statement that the tenants were not paying as in those $4^{\mathrm{T}} / 2$ years they have paid far more than the yearly valuation. It would appear that the rents were applied to puisne mortgages the representatives of some of whom admitted they had regularly received their interest.

Counsel for Lord Granard also relied on two letters written by the Lord Bishop of Elphin to Lord Granard which altho' not previously within my knowledge and not referred to in any affidavit were admitted in evidence as coming from a trustee.

These letters tho' used were not filed in court nor could I obtain copies until I had twice applied to Messrs Crozier and finally obtained an order from $\mathrm{Mr}$ Justice Monroe.

The letters are as follows:

Strokestown Mar. 5th 1888

\section{My Dear Lord Granard,}

I am summoned by the primate to attend a meeting of the Maynooth visitors at the college on the $13^{\text {th }}$ inst. for the purpose apparently of appointing a receiver over your estates.

Since I wrote to you I have received letters from Dr Browne in which he states that the proceedings taken by Mr Chance were forced on him in self protection by the course adopted by your solicitors which if not checked would deprive the college trustees of the means 
of enforcing payment of interest from the rents of your estate.

I shall be very happy if I can be of any service to you or if I can help to bring about an amicable settlement at our meeting.

I expect to return to Sligo on Thursday morning.

Your lordship's faithful servant,

L. Gillooly.

Sligo March 14th [18]88

My Dear Lord Granard,

I have just arrived from Maynooth and write this line for next post as I shall be absent all day tomorrow at dear old Fr Malachy Brennan's obsequies at Cliffoney.

The result of our meeting yesterday was despite all our wishes and good intentions not what I had hoped for. Mr Chance explained to the satisfaction of the bishops or at least in such a way as could not be contradicted by them the matters of complaint of which you and Lady Granard had informed me and showed that under the resolutions of the trustees and the advice of counsel he could not without violation of duty avoid filing the petition at the time he did and that it is now his duty in common with the trustees to take advantage at once of his position in court and obtain the appointment of a rec[eive]r.

On yesterday there was not a sufficient number of the trustees present to form a quorum and to act legally for them - all we could do was to direct that the appointment of a receiver once obtained no further unnecessary step to be taken before the June meeting of the trustees. The president was requested to forward to you the decision arrived at by our committee.

I hope they will lead to a satisfactory modus vivendi pending final settlements. Let me close these hasty lines by assuring you that the bishops assembled yesterday and as far as I know all the other bishops are most anxious to guard your interests as well as their own and to discharge their duty to the college without giving you or your family one moment's unavoidable pain or offence.

With best regards to Lady Granard and praying most cordially for better times.

I have the honour to remain,

My Dear Lord Granard,

Very sincerely yours,

+ L. Gillooly.

I regret I was not prepared for these letters which I fear prejudicially affected the trustees position. 
On the 27th April Mr Justice Monroe delivered judgement directing:

1. That a receiver should be refused

2. That carriage of proceedings be given to Messrs Crozier and that within a month from this date a deed should be executed by Lord Granard appointing $\mathrm{Mr}$ Darley rec[eive] $\mathrm{r}$ and containing a covenant to pay interest out of the rents according to priorities.

I obtained a copy of the judgement and sent same to Dr Browne for his perusal.

I did not feel justified without consulting with Dr Browne in allowing Judge Monroe's order to be made up making the trustees party to a deed appointing Mr Darley receiver and consequently on the 11th May I made an application to the judge who modified the order by directing Lord Granard to enter into a deed of appointment of Mr Darley as rec[eive]r when called upon to do so by the trustees but refused to amend the order by directing that in no event should the claim of the trustees be diminished by the payment of the costs of Messrs Crozier.

I do not think the trustees should be party to a deed appointing $\mathrm{Mr}$ Darley receiver as the course of conduct pursued by that gentleman as agent has been harsh and exacting and the trustees gain no substantial protection by the deed.

The trustees can only see that the proceedings for the sale of the estate are taken with due despatch and will in the light of the facts which appeared on the motion decide for themselves whether the remission of arrears of interest sought by Lord Granard should be given, or the full rate payable for default in punctuality should be exacted.

\section{P. A. Chance}

$22 / 6 / 88$

\section{8}

Messrs Darley and Roe to Rev Donnellan, 20 July 1888

$$
\text { MCA, } 110 / 17
$$

\section{Dear Sir,}

In reply to yours of 14 inst we regret very much that there is such a large arrear of interest due by his lordship to the trustees of Maynooth College. We have done our best to collect the rents and we are determined to use every means in our power to make the tenants pay. We may add that in the district of Drumlish there seems to be a very strong combination against paying any rents at all. If this could be got over the tenants would pay, and we would be in a position to pay the outgoings and interests due.

Yours very truly,

Darley \& Roe. 


\section{ARCHIVIUM HIBERNICUM}

29

Messrs Darley Q Roe to Rev Donnellan, 15 September 1888

MCA, $110 / 17$

Dear Sir,

In reply to your letter of the tenth we beg to mention that the receiver of rents since the 30 April last has been very small although every exertion has been made to get in and enforce the arrears. Out of the amount received $£ 1,433$, we remitted you $£ 1,000$ and we have had to pay taxes and other necessary estate outgoings which have absorbed the entire balance, besides advances have been made for the purpose of discharging the pressing estate claims. We will be happy to shew you the books or to any person who you may depute to satisfy you that nothing has been paid to the prejudice of the claim of Maynooth College since we have been acting as receivers under the deed which Lord Granard executed.

We expect that as soon as the harvest is saved there will be a considerable amount of rents paid in from time to time during the autumn which will be applied by us in strict accordance with the rights of the college.

Yours truly,

Darley \& Roe.

30

Messrs Crozier to Dr Browne 4 October 1888

MCA, $110 / 16$

Very Reverend Sir,

Notwithstanding that the applications which we have made on behalf of the earl of Granard to the trustees of Maynooth College for a reduction in the interest payable on their mortgage on his estates have not up to the present received the favourable consideration of the trustees his lordship has requested us to again bring the matter forward hoping that on a careful reconsideration of the entire circumstances the trustees will see their way to accede to his lordship's request.

Since the case was before the court, his lordship, acting on the suggestion of the judge, instructed us to prepare a receivership deed and his agents have since been acting strictly under it and they are prepared at any time to submit their accounts to any person whom the college may think fit to appoint to see that they have acted in strict accordance with their duties.

They have endeavoured in every legitimate way to get in the rents but although the prospect is we hope a very good one for obtaining their payment in the autumn of this year, still up to the present the receipts have not 
been sufficient to enable as large remittances to be made to the college as his lordship would wish.

We desire however to observe that it has always been the habit of the tenants on his lordship's estates to make their principal payments in November after the great fair of Longford on 22nd October and bearing this fact in mind we hope that the agents may be in a position to make satisfactory lodgments after that date.

Even if the tenants should pay, the money will all necessarily go to the college and meet the outgoings of the estate for rent charges, Board of Works instalments, taxes \&c which are very considerable and the result will be disasterous (sic) as regards the premiums on policies on his lordship's life for which no provision can be made unless the college see their way to lower the rate of interest pending a sale of the property.

We have been taking all the necessary steps in the Landed Estates Court to have the proceedings in that court carried on but the vacation has necessarily delayed the investigation of the title.

In anticipation that more money might be voted by parliament to enable tenants to purchase their holdings we have been in communication with some of the tenants but we cannot feel that they fully appreciate the advantages which would accrue to their acquiring the fee of their own holdings but if there should be more money voted we should expect that the tenants would be given to see the advantage which they would derive by purchasing at a fair and reasonable rate.

We trust that the subject will receive the favourable consideration of the college and that they will make allowance for the very altered circumstances of the country.

We are Very Rev[eren]d Sir,

Your obed[ien]t servants,

Thos Crozier \& Son.

\section{I}

\section{P. A. Chance to Dr Browne, 1 November 1888 \\ $\mathrm{MCA}, 109 / 4$}

Dear Dr Browne,

Last time I met you I mentioned that a man had been to see me with a letter from one of Lord Granard's tenants to him, complaining about the law proceedings that had been taken for rents.

Today the same man, a Mr John Maxwell of 49 Essex St. called again and told me he was asked by a tenant to say that Lord Granard had sold the timber on his land, or at least some of it to a timber merchant for $£ 1,000$ or $£ 1,500$. 
Of course this is very indefinite; so I asked my informant to get some particulars - including the name of the purchaser. This he promised to do.

Lord Granard has of course no right to cut the timber, and if he does so the court will probably appoint a receiver - much to the tenants' delight and also compel the proceeds of the sale of this timber to be lodged in court.

I telegraphed this to you and would be glad to have your instructions on this \& the question of the arrears of interest.

I would not advise you to write to Lord Granard or his representatives about this until we know for certain it is true.

I would suggest that I should be allowed to make enquiries about it quietly.

I am Dr Browne,

Yours sincerely,

P. A. Chance.

32

P. A. Chance to Dr Browne, 5 November 1888

MCA, $109 / 4$

Dear Dr Browne,

I hear that the buyer of the timber is a Mr McNeill who has a spool factory in Sligo, \& had one in Longford which it seems is to be reopened.

It seems he is giving $12 /-$ a ton for all timber over $3 ", \&$ is to take up to 10,000 tons.

This you can see would be a pretty saving out of the wreck (and out of the trustees' pockets).

I am also told that Coopers carpenters etc. are drawing timber every day from the demesne, $\&$ that the turf banks have been let at raised rents, and the proceeds pocketed.

What I fear is that Granard will get wind of what we are doing, and patch things up sufficiently to satisfy Judge Monroe.

If you can prove substantial misconduct as to the timber, I think a receiver would be appointed by the court, \& possibly carriage of the proceedings given to us.

A court receiver would be at liberty to recommend remission of arrears and his appointment would give the judge (under my section in the Land Act 1887) jurisdiction to remit arrears even against the owner's will.

Yours sincerely,

P. A. Chance. 
MORTGAGE PAPERS OF ST PATRICK'S COLLEGE, MAYNOOTH, I87I-I923

33

P. A. Chance to Dr Browne, 11 February 1889

MCA, $109 / 6$

Dear Dr Browne,

Today Messrs Crozier have served a notice that they will apply to Judge Monroe on Wednesday to have the proceedings stayed for 12 months to enable sales to the tenants, and to have the deeds etc. transferred to the Land Commission in order to carry out sales to the extent of $£ 52,000$.

I send you a copy of Mr Crozier's affidavit [illegible] the motion, and of a letter I have written to him today.

You will observe that so far we have not got any information as to the valuation or extent of the holdings about to be sold. The bare statement of the amount of the purchase money hardly enables one to estimate the propriety of the purchase transaction. I quite feel how desirable it will be to have sales made to the tenants; but we must see that everything necessary to enable the trustees to form a deliberate judgment sh[oul]d be disclosed by Lord Granard's advisers. For instance, are whole townlands sold, or only pieces picked out here and there, rendering the residue unsaleable. Who is to provide the guarantee deposit of $1 / 5$ the purchase money, and thus become sureties for the tenants? What arrangements have been made as to the arrears of rent? What has become of the rents collected last year? Were they applied in due priority to discharge the interest of each incumbrancer?

From my letter to Mr Crozier you will see that I inform him that we must apply for an adjournment long enough to enable the trustees to consider the whole case. I am by no means certain that the trustees can wisely consent to an order staying all proceedings before Judge Monroe for twelve months, especially as their proceedings have already induced Lord Granard to make an effort.

I don't like to express any opinion on the defective data before us, but judging from the statement that the unsold lands produce a rental of $£ 4,600$, I believe we will have reason to congratulate ourselves if the proposed sale is carried out.

I confess I am somewhat indignant that the trustees have been made parties to the deed appointing Messrs Darley and Roe wholly without their authority.

As to the timber I have not communicated with Mr Gilchrist lately, but there is little doubt he will be available when wanted.

Please let me have instructions as soon as possible.

Yours sincerely,

P. A. Chance. 


\section{ARCHIVIUM HIBERNICUM}

\section{4}

Copy Messrs Crozier to P. A. Chance, 12 March 1889

$$
\text { MCA, } 109 / 6
$$

\section{Dear Sir,}

We now forward you a full statement as to the sales herein, and annexed to it you will find tracings of the maps of the Longford and Leitrim estates, which we think you will find more satisfactory than an inspection of the Ordnance sheets, which are at present with the surveyor in the country. ...

We hope to send you in a day or two, a full affidavit as to the receipts and payments made by Messrs Darley \& Roe. It will show that all the rents have been strictly applied by them in accordance with the terms of the receivership deed. We have the affidavit and account in hands.

We regret to say that Lord Granard is not in a position to pay the arrears of interest. Through the kindness of friends, he obtained money on a recent occasion for that purpose but he feels that he cannot again appeal to them and in the present state of the money market, and also having regard to the present circumstances of the estate, it is quite out of our power to raise it.

His lordship feels that he has been doing his utmost to realize the securities in accordance with his undertaking to the court to carry on the proceedings with all proper diligence, and he hopes that the trustees will see their way to accept the four per cent interest which the tenants are to pay as the future rate on the purchased holdings.

With regard to the one-fifth retained by the government, Lord Granard hopes that when a further portion of the estate is sold sufficient to discharge the mortgage to Maynooth, the trustees will accept along with the money paid out of court, the guarantee deposit in full discharge of their mortgage security.

We remain,

Yours very truly,

Tho[ma]s Crozier \& Son.

35

P. A. Chance to Dr Browne, 15 March 1889

$$
\text { MCA, } 109 / 6
$$

\section{Dear Dr Browne,}

I have had but a few minutes to look over the account furnished by Lord Granard's receivers, but I find there was about $£ 250$ paid on account of agency fees, and about $£ 300$ on account of costs, and a couple of hundred 
MORTGAGE PAPERS OF ST PATRICK'S COLIEGE, MAYNOOTH, I87I-I923

more to the Property Defence Association, ${ }^{105}$ to special bailiffs etc., and that a very large number of payments fell due in 1887 , and should have been met out of the rents of that year....

You will recollect it came out in court that an enormous amount of money had been received by Lord Granard at a time when he was making a poor mouth to the trustees. We did not then know that Lord Granard had not even kept down the expenses of management etc. out of what he received, but it now appears that he neither paid the necessary outgoings on his estate, nor did he pay the Trustees. I should like to know what he did with his money.

Yours truly,

P. A. Chance.

36

Summary (approximate) of the account of Messrs Darley and Roe, the receivers on the Granard property, n.d. [March 1889?]

MCA, $110 / 18$

Receipts

From May 1st, 1888, to March 9th, $1889 \quad £ 4,958$

Disbursements

Rents, rates, taxes due and payable before the 1st May 1888 - about $\quad £^{1059: 8: 8}$

Processes, evictions, other law proceedings, tenants' expenses

of bailiffs, caretakers - about $\quad$ 411:13:6

$\begin{array}{ll}\text { Emergencymen }^{106} & \text { 172:2:3 }\end{array}$

Proceedings in Land Court, valuations, surveying - about 105:5:1

$\begin{array}{ll}\text { Agency fees } & \text { 230:0:0 }\end{array}$

Rents, taxes \&c due since 1st May 1888 - about $\quad$ 182:7:6

Miscellaneous expense 198:0:0

$£ 2358: 17: 0$

$\begin{array}{ll}\text { Paid to college } & \text { 2400:0:0 }\end{array}$

$£ 4758: 17: 0$

Balance on hands $\quad £ 199: 11: 4$

I05 Formed in December 1880 by a group of landlords and agents to combat the Land League. Both this organization and the Orange Emergency Committee, established in early 1880 for a similar purpose, sent so called 'emergencymen' to provide assistance to landlords during the Land War and the period of the Plan of Campaign; J. W. H. Carter, The land war and its leaders in Queen's County, 1879-82 (Portlaoise, 1994), p. 119.106 See footnote 101. 


\section{ARCHIVIUM HIBERNICUM}

\section{7}

Copy P. A. Chance to Messrs Crozier 3 May 1889

MCA, $109 / 6$

Dear Sirs,

I received from your representative today further statements, showing the holdings unsold, and the sales since the motion was first before the court.

I reserve my observations upon it, until I have examined it carefully. I find many of the unsold holdings are evicted: surely this will not form a saleable residue?

Please let me know what is the total tenement valuation of the holdings sold. I regret having to put you to so much trouble, but you understand that the particulars from time to time asked for have been quite necessary. Are steps being taken to sell the rest of the estate?

Yours truly,

P. A. Chance.

\section{8}

P. A. Chance to Dr Browne, 31 May 1890

MCA, $109 / 7$

Dear Doctor Browne,

I must apologise for not having sent you analysis of advances sooner. I now enclose it showing state of affairs in each townland. From it you will observe that originally $£ 99,978$ was asked. This leaves about $£ 20,000$ contracted for not yet dealt with by the commissioners. Of the $£ 99,000$ odd, $£ 72,972$ have been granted on the terms that $£ 15,262$ be left to the commissioners as a guarantee deposit. Thus the net sum so far available is $£ 57,710$. $£ 9,814$ has been wholly refused and in the cases in which loans have been granted the purchase money has been reduced to $£ 8,580$. The sums added to $£ 8,614$ which represents cases held over for further inquiry make up the $£ 99,000$ odd of which I have spoken.

Today Messrs Crozier wrote to me asking me what the trustees' opinion is as to the reduced advance and the increased guarantee deposit. They also promise me an account of income up to April last. Of course we cannot say anything until the trustees meet on the 24th but I would suggest that a summary be circulated amongst them as soon as possible and that the question of approving of the prices fixed by the commissioners be specially entered upon the notice convening the meeting. I am bound to admit that in my opinion a very good price has been on the whole obtained. ${ }^{107}$

107 Between then and the date of the next letter reproduced below, the bulk of the correspondence continues to centre upon the delays in carrying through the sale of estate. Due to the repetitive nature of this correspondence, it has not been reproduced. 
MORTGAGE PAPERS OF ST PATRICK'S COLLEGE, MAYNOOTH, I87I-I923

39

\author{
P. A. Chance to Messrs Crozier 11 March 1891 \\ MCA, $109 / 8$
}

I have received yours of the 1oth inst. and I regret to say that I feel compelled to write to you the letters you have already received. I think it was in May 1889 that the case was transferred by Judge Monroe to the Land Commission, yet I find that the title was not lodged until the 9th June 1890 , more than a year after, and that the draft turbary deeds, which were lodged on the ist May apparently before the title, were not sent me for approval until the year 1891. Again Lord Granard died in August or September 1889, and yet trustees were not appointed, nor an order taken out continuing the proceedings until November 1890 , showing another delay of a year. You state that you could not answer the rulings of the commissioners until you received my approval of the sales at reduced prices, but I have to point out to you that it was not until November 1890 that contracts were in existence in many of the cases, as before that date there was no one competent to execute them on behalf of the landlords. I have seen Mr McCarthy and he tells me of a fact which you did not communicate to me namely:- that there is some proposal to abandon the turbary deeds which I approved of and proceed by consent. I am perfectly prepared to adopt any course which will facilitate the proceedings but it seems to me that serious difficulties lie in the way of carrying out sales under vesting orders by means of consents. $\mathrm{Mr}$ McCarthy stated to me and authorised me to inform you that he is prepared to entertain favourably a proposal by you that the sales should be sanctioned at once on your undertaking to have the division of the bogs carried out, and that if this course is adopted he sees no reason why the money should not be lodged in the Bank of Ireland within 6 weeks. I regret again to feel compelled to express my opinion that there has been very great delay in this matter, and I cannot help recollecting that since the whole of the sum due to my clients will not be paid, it seems to me that your clients have no definite interest in bringing the case to a conclusion. You will recollect that you got carriage upon the production of evidence which induced Mr Justice Monroe to hold that the estate was amply solvent, and that interest would be paid to my clients from time to time, yet I find that a sum of about $£ 8,000$ is now due for interest, and it is clear that every day's delay inflicts a money loss upon my clients.

Yours truly,

P. A. Chance. 


\title{
ARCHIVIUM HIBERNICUM
}

\section{0}

\section{Thomas Crozier to P. A. Chance 13 March 1891}

\author{
MCA, $109 / 8$
}

\section{Dear Sir,}

We should like to have your views as to the terms on which we are to sell the remainder of the holdings which can be sold under the Ashbourne act. You will remember we wrote to you some time since as to the views put forward by the parish priest of Drumlish [Fr Thomas Conefrey], and as to the principle on which he wishes to purchase.

We have several times approached the tenants in the district (and who are no doubt guided by him) but we cannot sell to them unless we agree to give the holdings at from 10 to 12 years' purchase. We are not prepared to sell generally except on the same terms as we sold to the other tenants. If your clients however desire us to sell at from 10 to 12 years' purchase we shall bring their request under the attention of the trustees to ask their consent; or perhaps you would go over the statement you have as to the sales, and give us the purchase money which you think reasonable in each case.

Yours truly,

Tho[ma]s Crozier \& Son.

\section{I}

Fr Thomas Conefrey to Dr Browne, 22 March 1891

$$
\text { MCA, } 111 / 26
$$

[Noted along the margin: 'In 1887, two of Lord Granard's bailiffs went round here defaming the character of the trustees by holding them up as evictors. I send you a local history in which at page 113 you will get a short account of the fight with Granard'. ${ }^{108}$ ]

Dear Dr Browne,

I think it is best for the interest of the college if the trustees can manage to get the carriage of the sale.

I am prepared to prove on oath that the trustees lost the carriage of the sale on false evidence given before Judge Monroe on the occasion on which the trustees applied for the carriage of the sale. I read in the Freeman that one of the witnesses stated before the judge that the tenants were on good terms with Lord Granard and that they were prepared to buy on terms fixed by Lord Granard and Mr Crozier. That evidence was false. Mr Crozier met Lord Granard's tenants in my house about three years ago and they would 
not give within four years' purchase of what he demanded. Besides, Lord Granard and his half starved tenants down here were fighting for years and the fight would have terminated fatally only for the interference of your humble servant.

To be practical, the best way is to get the carriage of the sale, and I will engage that the tenants will do what is just and they have been treated unjustly themselves for generations past. Many of them have got from 70 to 30 per cent of reduction in the land courts.

I need not tell you that I regret the fearful loss inflicted on my alma mater by the Granard transaction. The tenants here are sorry for it, and will do all they are able to repair the loss.

Believe me,

My dear Dr Browne,

Yours faithfully,

Tho[ma]s Conefrey.

\section{2}

Fr Thomas Conefrey to Dr Browne, 9 April 1891

$$
\text { MCA, 111/26 }
$$

\section{Dear Dr Browne,}

In order to put an end to the humbug on the part of the lawyers engaged in the sale of the Granard property I have waited on the priests in the parishes where Granard's tenants have not as yet purchased, and have asked them to cooperate in getting the sales completed at once with a view to prevent additional expense on the part of the college. All of then have promised to do so.

I have asked Fr Michael Corcoran P.P. of Derawly [Scrabby?] to write to you and to tell you how matters stand in his parish regarding those tenants of Granard, who have not as yet purchased.

Canon O'Farrell P.P. of Newtownforbes told me that he will do all he can to bring about a just arrangement in the case of the tenants in his parish.

If Messrs Crozier and Darley will not agree to terms which a just tribunal will consider fair, they should be compelled to do it.

I have a thorough knowledge of all the dodgery that went on in Granard's castle with the Errington clique \&c. Any assistance I can give to get the college some of its just rights I will be most happy to give.

Believe me,

Dear Dr Browne,

Yours faithfully,

Tho[ma]s Conefrey. 


\section{ARCHIVIUM HIBERNICUM}

43

Fr Thomas Conefrey to Dr Browne, 15 April 1891

$$
\text { MCA, } 111 / 26
$$

\section{My Dear Dr Browne,}

I am authorized to state on behalf of the Granard tenants who have not as yet purchased in some adjoining parishes that they are most anxious to buy on just terms. Father Michael Corcoran P. P. of [illegilble] parish told me that the Granard tenants in his parish will purchase on the same terms as tenants on other estates in his parish have already purchased.

These are the terms viz the government valuation as a basis of purchase. Thirteen years' rent on the valuation. All arrears forgiven and their present turbary secured for the tenants.

The tenants in parish of Killoe have authorised me to state that they will purchase on the same terms.

So will Granard's tenants in parish of Barnacoola, Co. Leitrim (a list of whose names signed by themselves I enclose).

In this list they have given the gross valuation of houses and farms.

I come now to the parish of Clongish or Newtownforbes. I waited on Canon O'Farrell a second time and showed him your letter requiring his cooperation. He promised to do what he can in the matter.

I suggested to him to call a meeting of the tenants and take their views. As he is only lately appointed and may not thoroughly understand the state of things there yet, he said he would convene no meeting but will find out what are the feelings of the people regarding the sale of their farms. Now, it occurs to me that that course does not serve your purpose. What you want in the interest of the college is immediate action. I would suggest to you, therefore, to write to Canon O'Farrell and ask him the following questions:

First what are the agricultural tenants on Lord Granard's property who have not as yet purchased prepared to give for their farms? (You need not suggest any terms of purchase. Leave them full liberty of contract.) Secondly, on what terms will the tenants in the village of Newtownforbes buy out their houses and lands attached? Thirdly, can he ascertain whether it was the landlord exclusive of the tenants' assistance, that built the houses in the village? Or did the tenants build the houses at their own expense?

In the interest of a just and fair contract you can see it is necessary to have a correct answer to above questions.

I wish to make a few remarks about another source of security for the college - the demesne. Now, it is very valuable containing an amount of good land and timber which is worth a lot of money. Since the breakdown on the castle that timber is taken away in cartloads every day; the laurels and young trees were dug up and sold in the neighbouring fairs and markets, and desolation seems to be the order of the day there. Of course, if the college is not getting the money got for these things it loses so much. 
If I knew what the college intends regarding the demesne (of course I would keep such knowledge private) I would make such suggestions regarding the demesne as I consider in the interest of the college.

If Fr Corcoran has not sent in the offer on the part of his parishioners you should write to him and ask him to do so. I think you should write to Dr Woodlock as I consider Dr Conroy's house is rented in his name.

It is a pity that both the tenants and the college have been so badly treated by the servants of rack-renters. Any new suggestion tending to expedite the sales you can send and it will be acted upon by

Yours faithfully, Tho[ma]s Conefrey

P.S. Now, the lawyers engaged in the Granard business may say that our terms are too [sweeping?] and that the condition which wipes out the arrears should be consider (sic) on its merits in each individual case. Now this would lead to endless delay and confusion. The tenants in arrears as a rule cannot help it. They were rack-rented for ages. They are in debt to shopkeepers and to banks. Some of them had their crops destroyed by bullocks sent in upon them in summer before crops were ripe - the tenants having been previously evicted.

In 1882 and 1883 I had to provide for three hundred evicted families in this parish, many of them or the great part of them on the Granard estate. Only that I managed to get $£ 1500$ during that period and reinstated the evicted tenants, we had none of them today to purchase their farms.

These circumstances show that the condition requiring the forgiveness of arrears is not unreasonable.

T.C.

\section{4}

John George MacCarthy to Dr Browne, 21 April 1891

$$
\text { MCA, 111/19 }
$$

My Dear Dr Browne

Non-official

As our jurisdiction is based on the contract of the parties I have no power to intervene in any case in which a contract has not been lodged.

As regards the cases in which applications have been lodged very grave delay has occurred on the part of the landlord but at present his solicitors appear to be proceeding energetically.

Be assured that nothing shall be wanting on my part or on the part of our officers to expedite tem so far as we can do so.

Yours faithfully,

John George MacCarthy. 


\section{ARCHIVIUM HIBERNICUM}

\section{5}

\section{P. A. Chance to Dr Browne, 28 April 1891}

MCA, $109 / 8$

\section{Dear Dr Browne,}

I moved before Mr Comm[issione]r McCarthy today (1) to have the sales already sanctioned expedited (2) to draw attention to the owners refusal to accept Canon Cofrey's (sic) proposal. I filed an affidavit stating that the estate was insolvent and that the residue would become unsaleable unless the offers made were accepted. I stated the case and referred to the dates viz petition for sale 2 Feb[ruary] [18]88, carriage to owners 27 April [18]88, transfer to land court for sale 13 May [18]89, originating statement 29 June [18]89, Lord Granard's death Sept[ember] [18]89, lodgment (sic) of title 9 June [18]90, lodgment (sic) of turbary deeds May [18]90, return of said queried 8 July 1890, appointment of new trustees 17 Nov[ember] [18]90, \& directions for searches 11 Feb[ruary] [18]91 - all significant dates. I also pointed out the certainty of a deficiency \& the fact that an absolute order for sale was made by Judge Monroe \& the proceedings transferred merely in order to use the machinery of the land court for selling; and pointed out that the trustees alone are primarily interested in the amount of purchase money. Messrs Crozier (by their clerk) refused to accept the terms offered by Father Conefry (sic) and the comm[issione]r made a note in that part of the case 'owners refusing the comm[issione]rs have no jurisdiction'.

On the question of delay the comm[issione]r said 'he confessed he must say with regret but under the pressure of his judicial obligations that there had been grave and unnecessary delay in prosecuting the sales, chiefly in 1890 when during an interval of almost a year nothing effective was done to his knowledge'. Mr Darley who was present asked leave to make a statement. This was granted \& he said that he hoped to effect sales of the residue at much better prices than Canon Conefry (sic) offered. He declined to state that the estate was solvent, and admitted that he had kept back from sale. agricultural holdings adjoining the demesne but not separated by a wall, as he thought they w[oul]d sell better with the demesne.

It was also admitted that a rental of about $£ 1000$ (including the demesne) w[oul]d not be saleable in the Land Commission as the land was not agricultural, \& that the owners declined to take any step to sell this, until the land purchase sales were completed as 'they could not have proceedings going on in two courts at the same time'.

Mr Comm[issione]r McCarthy ended by requesting that the efforts made during the past few months sh[oul]d be continued and the estate wound up without delay. At my request he also directed Messrs Crozier to proceed to have the lay tithes redeemed.

It appears to me that the trustees sh[oul]d apply to Judge Monroe to direct the sale of the non agricultural land to proceed in his court without 
delay and that the tenants on agricultural holdings not yet sold sh[oul]d make definite written offers under the land purchase act which we sh[oul]d call upon Judge Monroe to accept. It seems perfectly idle to exempt the demesne from sale any longer. A deficiency is a certainty \& the demesne must be sold.

The position as far as funds seems to be:

Sales by Land Comm[ission] less purchase money of tithe rent charges etc.

Residue $£ 1,000$ a year at 15 y[ea]rs' purchase

Less costs of owner

It seems that 171 purchase contracts are stayed because of the gross inaccuracy of the survey lodged by the owner \& Mr McCarthy requested the owners either to correct the survey or employ another surveyor. 141 cases are stayed for other causes which Messrs Crozier have been requested to remove with expedition. These 317 cases cover a total sum of $£ 44,600$ but are included in my calculation which shews an available balance of $£ 70,000$.

I think the matter sh[oul]d be laid before the Trustees at once, \& I shall prepare a formal report \& send you 40 copies of it, if you wire me tomorrow,

Yours very truly,

P. A. Chance.

$$
{ }^{4} 6
$$

John George MacCarthy to Dr Browne, 28 October 1891

$$
\text { MCA, 111/19 }
$$

My Dear Monsignor,

\section{Confidential}

Of course, it would not be right for me to advise in a case which I shall have to consider judicially; but it seems to me that all parties concerned should consider the propriety of applying to the court under the provisions of the 14th sect of the Land Law Ireland Act 1887 to pay the proceeds of all sanctioned cases into the Bank of Ireland.

The advantage of such a course is that if the motion were carried, the fund would bear interest pending distribution. 
The disadvantage is that all antecedent rent and interest should (if not paid) be released except as to the last preceding half year. But this disadvantage is probably not considerable having regard to the poverty of the tenants, and the difficulty of obtaining decrees for ad interim interest in face of a recent decision of the Queen's Bench.

Yours Faithfully,

J. G. MacCarthy.

\section{7}

John George MacCarthy to Dr Browne, 10 December 1891

$$
\text { MCA, 111/19 }
$$

My Dear Dr Browne,

\section{Private}

It strikes me that the real difficulty in respect to the Granard estate will be the arrears of rent and interest due by the tenants and which must be paid, satisfied or released (except as to one gale) before the money can be paid into bank.

The advisers of the vendor may not deem themselves at liberty to sacrifice even the chance of recovering these arrears by legal proceedings.

On the other hand if the tenants were denuded of stock and capital by such proceedings it may become impossible to make advances to them at all.

In this state of things it may be worthy of your consideration whether you should not offer to give absolute credit for the amount of such arrears if the purchase moneys in all sanctioned cases be paid into the bank within some specified time and if reasonable progress be made in respect to the unsanctioned cases.

Yours faithfully,

J. G. Mac Carthy.

\section{8}

Fr Thomas Conefrey to Dr Browne, 11 December 1891

$$
\text { MCA, } 111 / 26
$$

My Dear Dr Browne,

I enclose a statement of the state of the tenants on the Granard property, which has been signed by the tenants who have not as yet bought out their farms.

This statement is now in the hands of Mr McCarthy of the Land Commission. I hope it may have the effect of showing Mr McCarthy the injustice done the college by multiplying costs in consequence of an unnecessary delay in effecting the sales. 
It is [?] to see how the parties managing the estate are acting.

A number of processes for rent were served here some months ago. The tenants took a defence and the Co[unty] Court judge postponed the trying of these cases till next March owing to some informality in the filling of the processes.

Mr Crozier has lately sent letters threatening the tenants with writs for rent which the tenants are unable to pay. Now all their proceedings involve law costs and the loss to the college must be enormous. It is with a view to stop such proceedings that I got a statement of the tenants sent to Mr McCarthy. If you think I can do anything more to expedite the sales suggest it and I will carry out your suggestion.

I am acquainted with all the details of the terrible war waged here for the last ten years between landlords and tenants. I am naturally anxious for a peace with honor as much as with justice.

Hoping yourself and your colleagues are well.

I remain,

My Dear Monsignor Browne,

Yours faithfully,

Thomas Conefrey.

\section{9}

John George MacCarthy to Dr Browne, 20 December 1891

$$
\text { MCA, 111/19 }
$$

My Dear Dr Browne,

\section{Private}

I hope you were satisfied with the result of Thursday's proceedings.

It seems to me that I have got the matter into a good groove and provided some remedy against the injustices from which you suffered.

This has, no doubt, been achieved at a pecuniary sacrifice to your trustees: but I really think that the sacrifice is more apparent than real.

Anyhow, it affords a conclusive answer to insinuations of hardness \&c which are too often levelled against ecclesiastics, and presents another illustration of the absolutely high-minded way in which your trustees have dealt with this matter so far as it came under my cognizances.

Mr Crozier has been at the commission nearly every day since and is now thoroughly alert.

Yours faithfully \& respectfully,

J. G. MacCarthy. 


$$
\text { MCA, 111/19 }
$$

In re[gard] The Granard estate

The tenants on above estate to J. G. Mac Carthy, Esq.

\section{Dear Sir,}

We, the tenants on the above estate, take the liberty of addressing you regarding grievances under which we labour about purchasing our farms of land.

A few remarks are necessary to enable your honor to understand these grievances. We beg to state that our land is intrinsically barren and would be unsuitable for agricultural purposes were it not for the great labour expended in reclaiming it from bogs and mountains. The land system which hitherto enabled the landlord to compel the tenant to pay for his own improvement was availed of to the full extent in our case. This is proved from the great reductions got from the land commissioners fixing judicial rents. Some tenants (who had means to put their lands in the courts) got reductions from 30 to 50 , and in some cases 70 per cent. Others, for want of means, were unable to put their lands in the courts, and were reduced to a state of beggary for striving to pay a rack-rent. When we got a chance of buying we were prepared to give a fair price for our farms. We offered, through our parish priest, the Rev Thomas Conefrey, thirteen years purchase, taking the government valuation of the land exclusive of the houses as a basis. As we built all the houses on our farms at our own expense we do not consider it just to continue the dishonest system of compelling us now when buying out, to pay for the fruits of our own industry.

The trustees of Maynooth College (who are the principal creditors, have accepted the terms offered through Father Conefrey. We agree to offer the same terms now. Any just man who knows the barrenness of our farms will acknowledge that our offer is fair and reasonable. That offer has not been accepted by Mr Darley.

Lately the estate lawyer has sent us letters threatening us with writs for arrears of rack-rents which we were unable to pay. If such writs will be executed we may as well abandon the farms altogether and will be compelled to go into the workhouse, as the execution of these writs would absorb all our means. There is no reason that can be assigned on our part why the sales cannot be effected at once on just and fair terms. We saw it alleged that the delay in effecting the sales on above property was due to disputes about bogs and other causes. We agree to allow such disputes to be settled by arbitration.

We wish to avoid an error into which some of our neighbours have fallen on above estate. Many of them bought when evicted with a view to 
get into their houses. They therefore promised to give a price for their farms which they find from experience they are unable to pay.

With these facts before your honor we ask for the sake of justice and charity towards ourselves and our distressed families to use your powerful influence to have the sales on above estate effected as soon as possible.

We have the honour to be,

Your Honor's obedient servants,

P.S. Any communication with which you honour us may be directed to Rev Thomas Conefrey P.P., Drumlish, Longford.

5I

P. A. Chance to Dr Browne, 25 January 1892

MCA, $109 / 9$

Dear Dr Browne,

Tomorrow an application will be made to lodge money in Granard. I shall of course apply to have it invested in G[rea]t Northern and G[rea]t Southern debentures as directed by his grace.

Y $[\mathrm{ou}] \mathrm{rs}$ sincerely,

\section{P. A. Chance}

52

John George MacCarthy to Dr Browne, 18 January 1892

$$
\text { MCA, 111/19 }
$$

Non-official

My Dear Monsignor,

I find that I was in error in supposing that I had agreed to have an anticipatory inspection made of the holdings respecting which no agreements have been lodged. The arrangement was that $\mathrm{Mr}$ Crozier \& $\mathrm{Mr}$ Chance should have the lands inspected by some valuer mutually appointed with a view to agreeing on certain advances to be asked for.

We have an inspector's report on most of these cases and will thus be able to decide on the proposals when made.

The non-agricultural holdings must be dealt with outside court. Perhaps Mr Chance and Canon Comphrey (sic) may be able to arrange that these holdings should either be purchased by the tenants for cash, or by some friendly outsider who would treat the tenants fairly.

Mr Crozier is making great efforts to keep his engagement and as I write three of our staff are helping him.

Yours faithfully,

J. G. MacCarthy. 


\section{ARCHIVIUM HIBERNICUM}

53

John George MacCarthy to Dr Browne, 27 January 1892

MCA, 111/19

Non-official

My Dear M[onsi]g[no]r,

I had yesterday the pleasure of making an order for payment into the Bank of Ireland to credit of the matter of $£ 41,188$.

This substantial sum represents the am[oun]t of the advances previously sanctioned, less $£ 10,876$ received for guarantee debts to which (subject to our claims) you will also be entitled and which bears interest at $£$ 2:15:0 per cent.

At the request of $\mathrm{Mr}$ Chance I directed $£ 2,500$ to be kept in cash for the redemption of certain charges, $£ 10,000$ in consols for further redemptions later on, and the rest in debenture stock of Great Northern and G[rea]t S[outhern] \& W[estern] R[ailwa]ys.

All investments are made by our official brokers amongst whom I have long since nominated O'Donnell and Fitzgerald. (The brokers take the order month by month in turn.)

I have also sanctioned a large number of other cases and directed $\mathrm{Mr}$ Crozier to apply in due course to lodge these costs also.

Mr Crozier suggested putting up the non agricultural lots for auction locally. This may be worth considering.

Crozier is really working the case hard - coming here personally almost every day and sometimes twice a day.

Chance is steadily watchful. Shrewd and helpful.

Yours faithfully,

J. G. Mac Carthy.

\section{4}

Estate of earl of Granard: G. D. Cochrane's report on Castleforbes demesne,

February 1892.

MCA, $109 / 9$

I have been requested by Messrs Crozier and Sons to estimate the saleable value of the residence and demesne at Castleforbes.

The mansion house or castle is of very considerable dimensions most of the building being comparatively new, with very extensive outoffices in the shape of sevants (sic) rooms, stabling, coach houses \&c \&c. In fact the buildings are in every way quite suitable for a man with an income of $£ 15,000$ to $£ 20,000$ a year. In what is known as the demesne there are about 574 acres of land in grass, 624 acres of wood, 205 of bog $\& 78$ acres let to tenants. Of the land in hands with the exception of some 25 acres none of it could be 
described as good. The rest though in grass is only third or fourth-class tillage land some of it very wet $\&$ much in need of thorough drainage. As the demesne has been planted with a view solely to appearance the land available for grazing or tillage is very much scattered and from a farming point of view so inconveniently situated that having regard to its poor quality an ordinary farming profit could not be made of it. The woods are of large extent comprising about 441 acres of upland \& 183 acres of bog. They on the map and at a distance look imposing but on close inspection it will be found that a great deal of the matured timber has been cut. There are a few hundred good specimen trees adjoining the house \& scattered here and there over the demesne.

Of the remainder there is a small proportion of marketable hardwood timber the bulk being spruce \& Scotch with some larch. In my opinion the nett value of the upland timber at present is $£$ 4:10:0 per acre and of the bog timber $£$ 2:10:0 per acre. Supposing the timber was at once realized by cutting it all down, the upland at present under timber I would value at 8/-per acre. The bog land at present under timber (if it should be cut down) would be worthless as the roots would not decay and it would not pay to remove them.

As regards the bog the villagers of Newtownforbes appears (sic) to have a right of free turbary upon it when the wants of these villagers are supplied there is no further demand for turf so that unless the bogs of all Ireland are by some scientific discovery rendered valuable, the bog has no marketable value except the contingency of some future value which I put at $f_{100} 0.0$.

Castleforbes house \& demesne is essentially a nobleman's or gentleman's residence. Treating it as a residence, its advantages are a large and handsome house with excellent outoffices placed in a prettily planted demesne lying along the River Shannon, a railway station within a mile and a half of the house, post office and telegraph office close to the front gate. Its disadvantages are - the buildings are only suitable for a wealthy man, no man with moderate means could live in them or keep them up. The question then to be considered is has the place such attractions as would induce a wealthy man to buy it? Granting the advantages above stated, there are no social advantages. The County Longford is now almost denuded of gentry, there is no hunting except a scratch pack of harriers got together this winter, there is no general shooting in the county and the place is three and a half hours from Dublin. Under these circumstances I cannot conceive a wealthy man buying it. In my opinion it will be found that in the market the castle and the offices are unsaleable and therefore valueless except as building material and for such there is almost no demand in the district. In fact it is doubtful if anything could be got for them as building material.

Believing Castleforbes to be unsaleable as a gentleman's residence estimate to value simply so much land available for farming, so much timber 
capable of being sold and so much bog. Dealing with it in this way my valuation is as under

Annual value of the land for farming

$£ 320$

Assuming timber to be all cut down

Annual value of land at present under timber

Market value

Twenty years' purchase of annual value

Present value of timber

Bog

18 years' purchase of land let to tenants

$$
\begin{array}{r}
f_{10,000} \\
2,442 \\
100 \\
1,152 \\
£ 13,694
\end{array}
$$

55

P. A. Chance to Dr Browne, 11 March 1892

$$
\mathrm{MCA}, 109 / 9
$$

Dear M[onsi]g[no]r Browne,

I enclose further letter rec[eive]d from Crozier this morning. Please return it. It is very positive as to queries. I note that $£ 52,000$ sh[oul]d have been lodged \& that only $£ 40,000$ odd was lodged.

Y $[\mathrm{ou}] \mathrm{rs}$ very truly,

P. A. Chance.

$$
\begin{gathered}
56 \\
\text { John George MacCarthy to Dr Browne, 30 March } 1892 \\
\text { MCA, } 111 / 19
\end{gathered}
$$

Non-official

My Dear Monsignor,

I had pleasure in making an order yesterday for payment into Bank of Ireland to credit of the estate of Lord Granard of a further sum of $£ 6,607$ exclusive of guarantee deposit amounting to $£_{1}, 8_{3} 0$ and representing the purchase money of $6_{5}$ holdings.

Permit me to suggest that Mr Chance might usefully ask vendor's solr for a schedule of all queried, refused, and pending cases with a view of ascertaining accurately what is being done in each case.

In the refused cases the acceptance of lesser terms did not come in until the Ashbourne funds were exhausted. The new applications must, 
therefore, be under the Act of ' $91{ }^{109}$ It may be well to explain this to the good Canon who so shrewdly looks to the interest of his people.

Yours faithfully,

J. G. MacCarthy

57

John George MacCarthy to Dr Browne, 31 March 1892

MCA, 111/19

Private

My Dear Monsignor,

The purchasers whose cases have been sanctioned and the bulk of whose arrears have been so generously forgiven should at once pay the half years interest which is their sole liability at present.

They have no defence whatever and no claim on any one moral or legal. I am sure that if the good Canon [Conefrey] understood this he would prevent what really would be a shame and a scandal - injurious to the interests of all honest tenant purchasers in Ireland.

Yours faithfully always,

J. G. MacCarthy

$$
58
$$

\section{P. A. Chance to Dr Browne 31 March 1892}

$\mathrm{MCA}, 109 / 9$

Dear M[onsi]g[no]r Browne,

Messrs Croziers' last letter to me states that the comm[issione]rs are satisfied with the answers they have given to the queries except ten which are amongst the last sanctioned. I have written to them for the particulars of these cases. I note that in the final schedule of incumbrancers Messrs Croziers' claim that their costs of sale should be paid in priority to the trustees' demand. You will recollect that Messrs Crozier got carriage on the assertion that the estate was perfectly solvent and that Mr Carton obtained Judge Monroe's promise that this would not be forgotten when their costs came in question. Under these circumstances I should like some instructions as to the propriety of objecting to give the costs priority. I also see that a judgment for $£ 5,000$ was given priority of the mortgages but this I think is right.

Yours sincerely,

\section{P. A. Chance.}

10951 \& 52 Vict., c.cii (5 Aug. 1891). 


\section{ARCHIVIUM HIBERNICUM}

\section{9}

P. A. Chance to Dr Browne, 2 April 1892

$$
\text { MCA, } 109 / 9
$$

\section{Dear M[onsi]g[no]r Browne,}

I have thoroughly investigated this case. 324 cases have been sanctioned \& $£ 52,064$ paid into the bank; of this $£_{10,876}$ is guarantee deposit. In 69 cases an order has been made to pay $£ 8,347$ into bank \& this includes $£ 1,830$ guarantee deposit. 6 cases in Co. Leitrim \& 3 in Co. Longford are pending. 14 in Co. Leitrim \& 109 in Co. Longford am[oun]t[in]g to $£ 20,655$ have been refused. The bulk of these cases were refused just because of am[oun]t of purchase money \& next (when re-lodged) because the Ashbourne money has been exhausted. Fresh agreements under the new act sh[oul]d be [illegible] but Messrs Crozier hope the comm[ission] may be induced to rescind their ruling \& allow these cases to be dealt with under the old acts.

I fear it will be difficult to displace Messrs Croziers' claim for costs, the rule of the comm[issione]rs being to give them priority. ...

Yours sincerely,

\section{P. A. Chance.}

\section{0}

John Reynolds, ${ }^{110}$ Drumlish, to Fr Thomas Conefrey 7 April 1892

$$
\text { MCA, } 111 / 26
$$

\section{My Dear Fr Conefrey,}

I am happy to tell you that your discourse to the tenants of Lord Granard on Sunday about their obligation to pay the half year's interest has had the desired effect.

In compliance with your request I have undertaken to send to Mr Darley any money that Lord Granard's tenants are bound in justice to pay.

A number of tenants have lodged their half years' interest with me since Sunday. Others who have not the interest at present have promised to get it when they can sell cattle in the coming fairs. All the tenants are anxious to do what is just but they were mislead (sic) by wrong advice. You have set them right.

I remain,

My dear Father Conefrey,

Yours respectfully,

John Reynolds P[oor] L[aw] G[uardian]. 
P.S. As I am prepared to pay ready cash for my land can you negotiate with Mr Chance so as that I may buy out my land at once? All cash received by me up to the present has been remitted to Mr Darley. All sums received in future shall be remitted at once.

\section{I}

Copy: Irish Land Commission Land Purchase (Ireland) Act: the earl of Granard's Estate: Opinion of Counsel (Mr Gerald Griffin), 30 April 1892

$$
\text { MCA, } 109 / 9
$$

The documents before me were

1. The abstract of incumbrances (no. 2) of 1842 June $13^{\text {th }}$

2. Report of Master Goold in the lands of Lottie v Leinster Lottie v O'Key and Lottie $\mathrm{v}$ [illegible]

3. Two draft schedules of incumbrances of the Longford estates the second being that settled by the examiner.

From these documents I have extracted the following statement of all such facts as appear to me capable of being by any possibility relevant to the questions raised by the order in which the charges in these estates appear in the schedule.

The Longford lands are in the schedule classed in two parts: Part I deals with lands which were owned by George Earl of Granard prior to October 31 st 1825 and part II deals with lands which were the property of George John Viscount Forbes acquired by him prior to October 31st 1825 .

The trustees of Maynooth College are entitled to a sum of $£ 91,592: 7: 2$ secured on lands belonging to the earl of Granard situate in the counties of Longford and Leitrim.

This sum is secured by mortgage of the Longford estates affected in the year 1843 and under the following circumstances.

In 1871 (sic 1781) 3rd of January the third earl of Granard being seized in fee created by a settlement a term of 10,000 years to raise a charge of $£ 10,000$. Of this charge the sum of $£ 5,613: 11$ :7 was still due in 1843 and this sum was in 1845 a first charge on the Longford estates. It is now vested in the trustees and the term is held in trust for them. It forms portion of the £91,592:7:2.

In 1781 July $4^{\text {th }}$ a term of 999 years was created by settlement to raise another charge of $£ 10,000$. Of this charge the sum of $£^{6} 516: 8: 2$ was still due in 1843 , and this sum was in 1843 the second charge on the Longford estates. It also is vested in the trustees and the term is held in trust for them. It forms another portion of the $£ 91,172: 7: 2$.

A large number of judgments were entered and registered against the earl of Granard between 1781 and the next deed of 1825 October 31st and he created also a number of annuities for lives. These formed charges on the Longford estates puisne to the two charges mentioned above. 
In 1822 Trinity term a judgment was entered up by Henry Marquis of Lansdowne ${ }^{111}$ against George John Viscount Forbes ${ }^{112}$ who had then no estate in the lands. This was a security collateral with a mortgage for $£$ [not specified] secured as a first charge on three townlands known shortly as Kennedy's Island purchased by George John Viscount Forbes. In 1843 the sum due on foot of this charge amounted to $£$ 4754:19:11.

In 1825 October 21st George Earl of Granard by deed granted all his estates subject to the incumbrances then subsisting in them and subject to two annuities (since expired) and subject to a charge of $£ 1200$ for his two daughters equally - to George John Viscount Forbes who undertook to pay the earl of Granard's debts. This charge of $£^{1200}$ is now vested in the trustees as part of the $£ 91,000$. Upon the execution of this deed the judgment of 1822 took effect on the estates conveyed to Viscount Forbes puisne to the then existing incumbrances.

Between the 31st of October 1825 and the date of the death of George John Viscount Forbes many other judgments were entered up effecting the estates so acquired by him and he also contracted speciality and simple contract debts.

In 1835 August the 11th George John Viscount Forbes under his will devised his estates to the duke of Leinster and others for a term of 900 [years] to pay his debts to secure and to raise certain legacies and annuities and subject thereto in strict settlement.

In 1836 November 30 th George John Viscount Forbes died.

In 1837 June $9^{\text {th }}$ George Earl of Granard died.

In 1837 May 9th Loftie, a judgment creditor filed a bill against the duke of Leinster and others to administer the estate of Viscount Forbes and carry out the trusts of the deed of 31 st October 1825 and Viscount Forbes will. The marquis of Lansdowne was a defendant in this suit and the persons beneficially entitled to his judgment were also parties.

In 1838 May 8th Loftie filed a Bill against O'Key to administer the estate of George Earl of Granard. A third suit was commenced by Loftie against Armstrong and others in reference to some of the charges.

1838 June 7 th the decree in these two suits made and Master Goold directed to report concerning priorities of incumbrances etc.

1842 June 13 th Master Goold reported.

1842 November 17 th final decree whereby the demands of the plaintiff and other persons found by the report (except the mortgage on Kennedy's Island) were directed to be paid and were declared charged on the lands mentioned in the pleadings. And it was ordered that the trustees should

\footnotetext{
III Born in 1780, the 3rd marquis of Lansdowne represented a variety of constituencies in Britain in the course of a prominent political career during which he held a number of cabinet posts including chancellor of the exchequer (1806-07) and home secretary (1827-8). He died in 1863; Burke's peerage and baronetage, pp 1539-40. 112 Eldest son of the 6th earl of Granard who predeceased his father. It was his son, George Arthur, who was offered the mortgage loan by Maynooth.
} 
MORTGAGE PAPERS OF ST PATRICK'S COLLEGE, MAYNOOTH, I87I-I923

raise by mortgage sums to pay off the incumbrances save the mortgages on Kennedy's Island.

In $1843, £ 171,000$ was raised and lodged in court. $£ 71,000$ of this was charged on the Longford estate and $£ 100,000$ on the Leitrim and Westmeath estates. The $£ 71,000$ was secured also on the Leitrim estates by a second mortgage. The $£ 100,000$ was afterwards paid off by sale of the Westmeath estates.

In 1843 August the 8 th a number of security deeds were effected to charge the lands in Longford with those sums. With respect to the $£ 371,000$ these were

(1) A mortgage of the term of 900 years under the deed of 1825 in the Longford estates.

(2) An assignment of the term of 1,000 years of 1771

(3) Do $999 \quad 1781$

(4) Do two sums of $£ 600$ charged by deed of 1825 .

These were also assigned by deed of same date two terms of 500 years and 1,000 years in portion of the lands in part II of the schedule viz: Tully, Brown Bog (Lisagernal [?]) and St Johnstown and which land secured a mortgage debt of $£ 2,300$ created in 1792 . This sum is believed to have been paid off some time after 1812 but the terms was not then reassigned and a term of 200 years to secure a life annuity of $£ 300$ which was thereby released.

Another assignment of same date was executed whereby Lofty (sic) the plaintiff in the three suits assigned the decrees and orders therein and the benefit of them so far as they effected the Longford lands as a collateral security for the sum of $£ 71,000$.

Also the legal fee in the Longford estates (then vested in Sir R[ichard] Levinge ${ }^{113}$ ) was by him conveyed in trust to secure the $£ 71,000$.

These several securities are now vested in the Maynooth trustees or are held in trust for them to secure the $£ 91,000$.

By order of 1843 August 14th out of the sums of stock in court stock was ordered to be transferred to the judgment creditors according to a report of the 1oth August 1843 on the said creditors producing warrants to satisfy their judgments. There were further reports made, not before.

I assume that the judgment creditors produced these warrants to satisfy their judgments and were paid the sums due them by transfer of sums of stock.

The mortgage on Kennedy's Island and the judgment of 1822 collaterally securing it were not paid off in 1843 , the owners thereof preferring to retain it and reducing the interests payable as an inducement to permit it to remain outstanding.

113 Sir Richard Levinge, 7 th Baronet, was born in 1811 and resided at Knockdrin in County Westmeath where he owned around 5,000 acres. He was MP for that county from 1856 to 1865 . He died in 1884 ; Burke's peerage and baronetage, p. 1599. 
In 1871 April 8th the trustees of Maynooth College agreed with the earl of Granard to lend monies to pay off charges and in the agreement it was stipulated that good title should be made to the terms of 900 years save as to the judgment of $\mathbf{1 8 2 2}$ if and so far as same might appear to be a subsisting incumbrance on the estates in priority to said term. Certain other mortgages were in 1844 executed pursuant to the decrees \&c. and amounted to $£$ [not specified] in equal priority with the mortgages for $£ 71,000$. Since these mortgages an exchange was effected of a small portion of the lands which are now substituted by others.

A petition for sale in the Land Judges Court was presented and order made thereon and the matter has been transferred to the land purchase department of the Land Commission.

The examiner I settling the draft schedule of incumbrances has arranged the priorities of the several charges on the lands mentioned in part I of the schedule as follows -

After costs, quit and crown rent, tithe rent charges, and drainage loans

1. The charge secured by 1000 years term created in 1771 belonging to Maynooth trustees $£ 5613: 11: 7$

2. The charge secured by 999 years term created in 1781 belonging to Maynooth trustees $£^{6} 516: 8: 2$

3. The judgment of 1822 belonging to Hort $£$ [not specified]

4. The charge of $£ 1200$ created by deed of 31st Oct. 1825 belonging to Maynooth trustees $£ 1200$

5. The residue of $£ 91,592: 7: 2$ secured by mortgages of 8 th Aug[us]t 1843 and subsequent mortgages belonging (sic) to Maynooth trustees.

As the estate is likely to prove deficient the question of the priority given to the judgment of 1822 becomes of importance. The following observations occur to me as bearing on this question:

1. Is this judgment entitled to priority over the $£^{1,200}$ created by deed of 1825. I think it is not so entitled but should rank puisne to the charge of $£ 1,200$ on the following grounds. At the date of the judgment George John Viscount Forbes against whom it was obtained had no interest whatsoever in the estates included in part I of the schedule. The judgment then did not effect the lands and could not effect them until he acquired some interest therein and would only effect such interest as he acquired.

The deed of 31st Oct[ober] 1825 was the one by which he acquired an interest. But that interest was subject to the previously existing incumbrances and also expressly subject to the $£ 1,200$ charge created by that deed. The incumbrance of the judgment creditor than (sic) attached only to Viscount Forbes's interest in the lands and was thus as a charge puisne to the charge of $£ 1200$.

(As to the lands in part II of the schedule which were the property of the Viscount Forbes prior to 1825 the judgment is entitled to the priority given it by the examiner.) 
2. Part of the monies advanced by the mortagees of 1843 and 1844 (who are represented by the Maynooth trustees) having been applied to the purpose of paying off judgments which were incumbrances prior to the judgment of 1822 (i.e. judgments against George Earl of Granard obtained before Oct[ober] 31st 1825) and having been advanced pursuant to the decree of the Court of Chancery should not the mortgagees be deemed to stand in the shoes of these judgment creditors in respect of the monies contributed by the mortgagees which the court used to pay off these prior judgments so as to give priority over the judgments of 1822 .

The principle suggested appears to be equitable and to be somewhat analogous to the equity marshalling funds. But I have been unable to find any authority to sustain it. It is true that in two Irish cases Green v Stoney (Ir. Eq. R. 301) and Kirby v O'Shee (1 Jo. 565) mortgagees were held entitled to stand in the place of judgment creditors. But in both these cases the mortgagees had obtained assignments of the judgments a fact which of course entirely distinguishes these cases from the present. See also Parry v Wright (1 Sim. \& St 369), and (5 Russ. 142); and Medley v Horton (14 Sim. 226). Again what happens if (as would seem to be the case) the judgments the priority of which the Maynooth trustees desire to obtain, have to be satisfied of records? Such judgments are dead. How can they be used for any purpose?

Again these judgments have not been re-docketted (sic) and re-registered pursuant to statute. How then can they remain effectual against the owner of the judgment of 1822 who is a 'creditor' within the terms of the 7 and 8 Vic. and C. 90 35. 2. \& 6, athough not a 'purchaser'?

In 1843 the mortgagees consented to let their judgments remain outstanding. If they had desired they could have insisted on its being satisfied of record (Fitzgerald v Land (3 Eq. R. 339)) or they could have insisted in his joining in the conveyance to them to postpone his charge. Or lastly they might have stipulated that the prior judgments should be assigned to them, instead of having them satisfied. If they had taken this course there could have been no question about their priority - See Watts V Symes (1 De. G. M. \& G. 240); Adams v Angell (5 Ch. D. 646) also Phillips v Gutteridge (43 De G. and J. 531).

For all these reasons I am of opinion that the Maynooth trustees are not entitled to the priority of the judgments paid off out of their money. Although I am unable to feel doubt on this point, I am sensible of the slight value of my own opinion, and considering the large sum of money at stake, I strongly recommend that the opinion of senior counsel be taken on the point.

3. If (as I gather) the lands called Kennedy's Island, on which the moneys secured by the judgment of 1822 are a first charge by virtue of a mortgage collateral to the judgment, are not part of the security to the Maynooth trustees, cannot the latter marshal in respect of the two sets of lands? 
I am of opinion that should the owners of the judgment and mortgage on Kennedy's Island, elect to resort to the funds produced by sale of the estates on which alone the Maynooth trustees have their charge secured the latter are entitled to stand in the shoes of the owners of the judgment in respect of the mortgage on Kennedy's Island. This equity should be enforced I think in a substantive proceeding against the three townslands (sic) called Kennedy's Island, assuming that those lands are not included in any petition.

Gerald Griffin,

77 Harcourt Street,

Dublin.

April 3oth 1892.

\section{2}

Statement issued on behalf of Granard estate tenants, n.d. [c. 16 May 1892]. ${ }^{11}$

$$
\text { MCA, } 111 / 26
$$

We the undersigned purchasing tenants on above estate testify that we met Mr Rafferty the steward from Castleforbes in the house of Rev[eren]d Tho[ma]s Conefrey P. P. of Drumlish on the 16th inst and that said Mr Rafferty on date mentioned produced a list of the names of us purchasing tenants and that opposite each tenant's name was given the amount of purchase money which the tenant was expected to pay for his farm. That amount of purchase money according to Mr Rafferty's statement was the amount fixed upon each farm by Mr Barrington increased by one year's rent which year's rent was added on account of arrears. Mr Rafferty on occasion mentioned produced a letter from Mr Crozier in which the latter stated the year's rent should be added according to instructions given by the trustees of Maynooth College through the advice of Father Conefrey. We agreed to pay according to Mr Barrington's valuation with the year's rent added to said valuation. We agreed to this for peace sake though we believed in justice we were giving too much for our farms.

When we came before the magistrate on the 17th inst to sign the agreements as arranged on previous day Mr Rafferty produced a new list of our names and increased the purchase money in every instance. We considered this unfair. We refused to sign the agreements on such terms. We will insist on getting an authentic copy of Mr Barrington's valuation either from $\mathrm{Mr}$ Barrington himself or from $\mathrm{Mr}$ Chance and we will abide by $\mathrm{Mr}$ Barrington's valuation solely without any additional year's rent added to it.

Anyone who knows how we have been rackrented for farms reclaimed out of bogs and mountains how we have been persecuted by the late Lord Granard and his emples (sic) must admit that our offer is not only just but generous. An example will show how we would have been wronged if we 
accepted the terms offered on 17th inst by Mr Rafferty. In case of James Molloy undersigned Mr Rafferty told him on 16th inst that his purchase money was $f_{1} 60$. On 17 th inst he stated that the purchase money was raised from $£_{16} 6$ to $£ 180$. The same proportional increase was made in each case. We will not stand each injustice from the representations of the rackrenters of Castleforbes.

We the undersigned purchasing tenants:

James Molloy

Michael Larkin X

John Carolan

James McNally

Bernard Carolan X

\section{3}

P. A. Chance to Dr Browne, 5 January 1893

MCA, $110 / 10$

\section{Dear Dr Browne,}

I attended yesterday before the Land Judge's examiner with Mr Crozier and it was arranged that we should move on the second day of term to have the proceedings revived for the purpose of conveying the demesne etc. to Lady Granard. I fear this will be a somewhat lengthy operation, but we need not care as Mr Crozier has promised me to have the purchase money invested in joint names, in such securities as you approve so that we shall get the interest while the law proceedings are going on.

I have not yet heard from anyone a definite statement of what Lady Granard is purchasing outside the demesne. I understand there are other unsold bits of townlands which are to be included and Mr Crozier thinks the residue, upon which the government refused to make any advance might be sold to gombeen men, a course which I am sure you would not desire, if you could possibly avoid it.

I have also asked him to take some steps to have Kennedy's Island, and the other lands not included in our mortgage sold to the tenants. I understand they are worth between $£ 3,000$ or $£ 4,000$ and as the trustees will stand in Professor Hort's place the entire of this sum will come to us.

Kindly let me know from who I shall get a definite statement of the bargain with Lady Granard and also directions as to the stock and names in which her purchase money is to be invested.

Yours sincerely,

\section{P. A. Chance.}




\section{ARCHIVIUM HIBERNICUM}

\section{4}

Edward Darley to Dr Browne, 7 July 1893

$$
\text { MCA, } 110 / 17
$$

\section{Dear Sir,}

As I informed you at the interview we had the rent which was fixed on Father Conefrey's holding referred only to one of his holdings no. 233 on rental. The old rent of this holding was $£ 5: 14: 6$ and as you will perceive by the enclosed document it was fixed at $£ 3$. This new rent would run from 1st May 1889. The rents of his other holdings have not been altered nor, so far as I know, can ever be altered by the Land Commission. He owes now $£ 47: 1: 9$ and I shall be glad to have your instructions whether I am to apply to him for this money or not.

Yours faithfully,

Edward Darley.

\section{5}

Patrick Rooney [for P. A. Chance] to Dr Browne 10 July 1893

$$
\text { MCA, } 110 / 10
$$

Dear Dr Browne,

Mr Chance writes me this morning that he has no suggestion of any practical value to make as to the realization of the residue of the above estate, inasmuch as no one is likely to give any reasonable price if the tenants wont buy, and the tenants know this perfectly well and act accordingly.

The difficult problem is to get any price at all for the holdings which the land commissioners decline to advance money upon; and as to these my only proposal is to induce a few of the richer tenants in each district (if such there be) to buy on a bargain to resell within 10 years taking 5 or $6 \%$ for their money in the meantime, as rent. The richer men could buy at very low rates and $5 \%$ of their money would enable them to cut down the present rents very largely. Probably a consolidating movement would set in amongst the poorer tenants under this plan, and we might finally arrive at holdings large enough to satisfy the land purchase commissioners.

Yours respectfully,

Patrick Rooney for Mr Chance. 
MORTGAGE PAPERS OF ST PATRICK'S COLLEGE, MAYNOOTH, I87I-I923

66

Edward Darley to Dr Browne, 17 August 1893

MCA, $110 / 17$

Dear Sir,

I am much astonished to learn from $\mathrm{Mr}$ Crozier on my return to business that you had stated that I had neglected to call on their tenants for their rents and interests during the last couple of years. Whoever told you this told you what was not true. I have had any number of collections, and the tenants all over the estate have been fully advised, both by printed posters, and also by the bailiffs calling on them and seeing them personally, and in many cases each of the tenants had besides a printed circular sent them showing the amount due. Of course one cannot be surprised that the tenants do not pay any rent or interest when they have the example of their parish priest before them.

Yours faithfully,

Edwd J. Darley.

67

Edward Darley to Dr Browne, 7 July 1893

MCA, $110 / 17$

Dear Sir,

As I informed you at the interview we had, the rent which was fixed on Father Conefrey's holding referred only to one of his holdings no. 233 on rental. The old rent of this holding was $£ 5: 14: 6$ and as you will perceive by the enclosed document $t^{15}$ it was fixed at $£ 3$. This new rent would run from 1st May 1889. The rents of his other holdings have not been altered nor, so far as I know, can ever be altered by the Land Commission. He owes now $£ 47: 1: 9$ and I shall be glad to have your instructions whether I am to apply to him for this money or not....

Yours faithfully,

Edward Darley.

II5 This document does not seem to be available. 
68

REPORT OF THE CLERICAL COMMISSION

Appointed to confer with the tenants of the unsold residue of the Granard estate

MCA, $111 / 25$

\section{TO THE MOST EMINENT AND MOST REVEREND THE TRUSTEES OF MAYNOOTH COLLEGE}

We have the honour to report to your lordships the result of the commission with which we were entrusted by a resolution of your board, dated 27th of June, 1893, "to visit the unsold townlands of the Granard estate, and confer with the tenants as to the terms on which the unsold lands would be purchased by the occupiers, with a view to reporting to the autumn meeting of the board, for the consideration of the trustees, such arrangements as they may find themselves able to recommend as to the result of the negotiations.'

As the unsold residue mentioned in the statement presented to your lordships at the recent board meeting by the Messrs Crozier is almost entirely situated in the districts that surround Longford, Newtownforbes and Drumlish, we fixed upon those towns as centres to which the tenants could conveniently come for the conference. We spent four full days in receiving them, one by one. In all about 140 tenants appeared before us to explain the transactions that have taken place in recent years in regard to their tenancies and their present condition, and to make offers for purchase. We have printed the details of each interview in a separate report, which will also be presented to your lordships for your instruction and guidance, and which is, for obvious reasons, to be regarded as a confidential document. We have accordingly marked it 'Confidential'.

We were attended, during the conference with the tenants, by the law clerk of Messrs Crozier and by the local agent or steward of the estate. The president of the college informed us that he invited the agent, Mr Darley to accompany us, but Mr Darley excused himself from attending on the ground that he was about to go on vacation.

In this report we purpose (sic?) to lay before your lordships, for your information and guidance, such observations and recommendations regarding the unsold residue 'as we find ourselves able to make as the result of our conference and negotiations with the tenants.' 


\section{OBSERVATIONS}

\section{THE CROZIER 'STATEMENT OF RESIDUE'}

The president of the college informed us that the document called 'Statement as to the residue of the estates' was sent by the Messrs Crozier, through him, for the information of your Lordships at your recent board meeting last June. Assuming the document - which was presented by the solicitors for the estate who have also carriage of the sale to your board in response to an application for a full statement of the unsold residue - to be correct, we naturally took it with us to be our guide. We soon found it, however, to be inaccurate in some, and misleading in several important particulars. For instance:

1. In some cases the tenants have had for a considerable time 'judicial' rents, but the Crozier statement sets forth quite a different rent, and generally a higher one. (See numbers 108, 109, 112).

2. In the great majority of cases mentioned in the Crozier 'Statement of residue', the tenants had at some time (generally in the year 1889 , or in 1890) signed agreements with the landlord for the purchase of their holdings for a definite sum. Now the consequences of such agreements were:-

a. That, from the date of such agreement the tenant was to pay, as the law provides, at the rate of 4 per cent on the amount of purchase, and that this interest or yearly instalment was to take the place of the former annual rent. The interest was received by the agent for one or more gales. Now, we found set down as rent in the Crozier 'Statement of residue' (given to us for our guidance) in practically all these cases not the annual interest on the purchase money, or even a reference to it, but the old rent which is notably larger, and which once that an agreement to purchase had been made, practically ceased to exist, except on paper. This was very misleading

b. Again, when the agreement to purchase was signed, some arrangements regarding arrears must have been come to, as the Purchase Commission could not sanction any case in which the tenant continued in debt for rent beyond one half year. Yet we found that in the Crozier 'Statement of residue' the amount of arrears is not calculated on what has been unpaid since the date of agreement to purchase (indeed little account is made of such arrears in most instances), but when arrears are mentioned at all, they are, as a rule, the arrears that had accumulated for years preceding the date of the agreement to purchase. Such a document is very misleading. It would be obviously of much more importance to let your lordships know what tenants had signed agreements to purchase, and for what 
amount; and to inform you of those who had failed to pay the annual instalments, and why.

3. An inaccuracy, which is in curious contrast with the one we have just mentioned, is the following:- namely, that in not a few cases where the tenant has not paid rent for years, and has continued to the present to pay no rent, he is set down in the Crozier 'Statement of residue' as having an entirely clear record under the heading of arrears. (See Nos. $86,88,89,90,102,126$.

4. Lastly, we have to bring under the notice of your lordships that some holdings, and a number of valuable tenements, situated in the town of Newtownforbes, were omitted altogether from the Crozier 'Statement of residue.' Neither was there any mention in it of the property known as 'Kennedy's Island'.

We mention these matters to show your lordships the character of an official document presented for your information as to the present condition of the estate.

II

\section{THE CESSATION IN THE PAYMENT OF INSTALMENTS}

In connection with the agreements to purchase made between landlords and tenants some years since, we have to report that several tenants, who have not paid the annual instalment for the past year or longer, excused themselves on the ground that contrary to the custom of the estate, they had received no application for rent from the agent or bailiff, or rent-warner, or by letter, or in any form for the rent. (See Nos. 38, 90, 112, 117, 125, 129, 249, $250,251,253$.) Several of the tenants told us that they would have willingly continued to pay the instalments half-yearly, if they had been asked for them, but that it was now quite a different and much harder thing to pay the accumulated rent which was allowed to run on through no fault of theirs. In some cases, we brought the rent-warner face to face with the tenants, and the rent-warner had to admit that he was not commissioned to give, and, as a matter of fact, did not give them the usual notice for the payment of rent during the period mentioned by the tenants. The agent will, we presume, explain to your lordships how this happened; but the statement of the numerous tenants, if true, reveals the state of disorganisation on the property.

\section{III}

\section{THE LEGAL METHODS FOR PRESENTING THE AGREEMENTS FOR PURCHASE BEFORE THE LAND PURCHASE COMMISSION}

Another observation has occurred to us in connection with the agreements for purchase:- 
As we have stated already, most of the tenants on the unsold residue signed agreements to purchase. They had done their part, so far as they knew, and naturally left the legal aspect of their case to the lawyers in charge, now, we find that when the cases came before the Land Purchase Commission, most of them had to be set aside, now for one obvious legal defect, and again for another, such as the following:- the boundaries of tenancies were not defined; or the holding was held jointly by two tenants; or the tenant had on his holding an under-tenant; or the tenant was not in occupancy, and so forth.

It would seem to be an easy thing for a lawyer to inform himself of the rules of the Land Purchase Commission, and, consequently, an easy thing to understand that such cases could not be accepted by them. We do not know what effort, if any, was made to prepare the cases in accordance with the rules of the Land Commission, but the manner in which they were presented seems to have resulted in greater delay in effecting the purchase, in a feeling of great dissatisfaction in the minds of the tenants, and in an all-round loss to the trustees of Maynooth.

\section{RECOMMENDATIONS}

1.

It seems to us to be hopeless, speaking generally, to expect from the tenants the payment of arrears, and consequently inexpedient to obstruct the sales of their holdings to those who offer a reasonable price ex nunc, by insisting on the payment of arrears. In most cases, practically in every case, arrears cannot be exacted without a slow and expensive process of law; and the law expenses and the loss of current rent will more than counterbalance any payment of arrears secured in this way. This remark applies with greatest force to the poorer tenants.

\section{2.}

We recommend that the cases of the tenants on the unsold residue be reexamined and prepared by the lawyers, in the light of the rules of the Land Purchase Commission, and remitted to it for their acceptance. The Land Purchase Commission is willing to take up again all rejected cases that fall within its jurisdiction.

3 .

At to the price to be fixed on the different holdings, we feel justified in recommending your lordships to accept the price which our Clerical Commission declares, as the result of their investigation, to be satisfactory. There are many cases in which we can so declare.

Agreements to purchase should be sent to such tenants for signature at once. Delay is injurious to your interests, and also harmful to the material and moral interest of the tenants. 
4 .

In case of disagreement or doubt as to the purchase price, we recommend to get, if possible, the valuation of the Land Purchase Commission, and to abide by it.

If the Land Purchase Commission will not interfere, before an agreement to buy for a definite sum be entered into between landlord and tenant, we recommend that in such cases our Clerical Commission, in consultation with the two bishops already in charge of this work, would fix upon the price in each case, further investigation, if necessary, being made for the purpose.

5.

We recommend the appointment of a small committee, with power to decide questions which cannot be settled at present, regarding price of purchase, boundaries, turbary \&c. it would be for this committee to utilize the aid of the local priests for purposes of inquiry or mediation, to direct the solicitors to accept offers which they (the committee) approve, and so forth. We are satisfied that five-sixths of the outstanding cases can be settled speedily, if only a little energy and earnestness on the part of those having authority to act are used in following up the work of sale.

When the great majority of cases are settled, it would be much easier to deal with the few troublesome tenants than it is at present.

6.

As the cases which present difficulty are largely dependent on the apportionment of turbary, we feel it a matter of great importance to advise your lordships not to part with any portion of the bog lands which must be available for distribution, if the tenants are to become the purchasers of their holdings. We are not without much fear that it is in the mind of the estate representatives to possess themselves of large sections of bog. If this be allowed, great dissatisfaction among the tenants, and considerable depreciation of their holdings will be the result.

7 .

As a consequence of what we have just stated, it is a matter of great importance that you should get at once the map of the demesne and other portions recently sold to Lady Granard. This map should set forth exactly the measurements given in Mr Cochrane's report and valuation which determined the full extent of the lands sold to Lady Granard. The president of the college informed us that he applied to Messrs Crozier again and again for this map, and has failed to get it.

8.

We venture to express strongly our conviction that, after your appointment of a commission to negotiate with the tenants, there is no course open to your Lordships but to sell the whole of the residue to the tenants in occupation. 
We are informed that an attempt has been made, since our commission to confer with the tenantry was approved, to buy portions of the residue over the heads of the tenants in occupation - that, in fact, Lady Granard has made a proposal for the purchase of the village of Newtownforbes. It is alleged, in her favour, that Lady Granard did not get a prior opportunity to purchase. But how can this be a fact? Has not Newtownforbes been in the market since the Granard property was set up for sale? Yet there was no proposal all this time on her part. Is not Newtownforbes set down in the very statement of unsold residue which was presented to your board by her solicitors, and which was put into our hands when setting out to 'confer with the tenants and negotiate with them for the purchase of the unsold residue'? Yet up to the time when the tenants, relying on the bona fide character of the commission entrusted to us by your lordships, came forward in response to our invitation and made offers, in most cases reasonable offers, for the purchase of their holdings, no offer was made by Lady Granard to buy Newtownforbes.

It occurs to us that the tenants would have a very reasonable ground of complaint, if their confidence in your commission which elicited their honest bidding, was not treated seriously, but suffered to be used as a mere spur to hasten on the purchase of their holdings by another.

It must be borne in mind too that a sale to the tenants will realize at least as much, and according to our calculation considerably more, than the latest offer made by Lady Granard.

Finally, we understand, that the experience of a recent purchase effected by Lady Granard has not been in all respects so satisfactory as to encourage a second experiment in opposition to the interests of the tenants.

ROBERT BROWNE

JOSEPH CANON HOARE

JAMES CANON O'FARRELL

JAMES DONNELLAN

\section{POSTSCRIPT BY THE PRESIDENT OF THE COLLEGE}

There are some matters connected with the unsold residue of the Granard property which I have learnt as the result of personal enquiry, and which seem to me of too much importance to withhold from your lordships.

Before proceeding to Longford on the business of our Commission I called on Mr Commissioner O'Brien at the offices of the Land Purchase Commission, to learn from him, if possible, how matters stood.

In reply to my inquiries, Mr O'Brien had no hesitation in strongly censuring the delay in closing these sales, and then, placing his hand on a bundle of Granard cases which lay on the table, and which, for one legal defect or another could not pass his court, added that he had complained of 
the management of the matter again and again to those having the carriage of the sale, but with little effect.

On the day following my interview I received the following letter, which will give your lordships some notion of how the business has been conducted:

The Irish Land Commission, 24, Upper Merrion Street, Dublin, 8th July 1893

Rev[erend] Sir,

I am directed by the Irish land commissioners to transmit to you herewith the enclosed copy of a letter written by them to Messrs Crozier and Son, and to state with reference to your interview with Mr Commissioner O'Brien yesterday, the letter will show how matters stand as regards the sale of the estate.

Your obedient servant, JOHN H. FRANKS

THE PRESIDENT,

St Patrick's college,

Maynooth.

[copy]

The Irish Land Commission,

24, Upper Merrion Street,

Dublin, 8th July 1893.

\section{ESTATE OF THE EARL OF GRANARD}

\section{GENTLEMEN,}

I am directed by the Irish Land Commission to inform you that further complaints have been made as to the great and continued delay in closing the sales which have been sanctioned on this estate.

It appears that in addition to the 78 cases in which vesting orders have been recently lodged and settled, there are 26 cases in which the money has been paid into bank; but the draft vesting orders for which have not been lodged.

There are 44 cases, some of which were sanctioned so long ago as March and April, 1891, and as to which there is no reason why they should not have been paid under the $14^{\text {th }}$ section long ago; nor is there any reason why the vesting orders in the above cases should not have been lodged before this.

In explanation of previous complaints made by the land commissioners as to the undue delay in the carriage of this sale, it was 
MORTGAGE PAPERS OF ST PATRICK'S COLLEGE, MAYNOOTH, I87I-I923

represented that delay was caused by the necessity of obtaining the consent of the trustees of Maynooth to the certificate under Rule 85.

The commissioner is informed that the trustees have always been, and are ready to give any consent that may be necessary to expedite the sale, as the prolonged delay in closing the sales has already caused them serious loss and inconvenience.

Your obedient servant, MESSRS THOMAS CROZIER AND SON

On my return from Longford I again called on Mr Commissioner O'Brien to make enquiries as to the effect of selling the holdings in the Land Judges' Court, rather than in Purchase Commission.

He informed me that the sale through the Land Judges' Court would be of the slowest and most expensive kind. The expense of making out title would in many cases amount to more than the purchase. In fact, the sale of the separate holdings to the tenants would be practically impossible in the Land Judges' Court. Yet, your lordships will note that in the Crozier statement nearly all the holdings are marked 'To be sold in the Land Judges' Court'.

I then asked Mr O'Brien to take up again in his court the cases which had been rejected by it formerly for one cause or another. He promised to do so and added that it was competent for his court to deal with the holdings in the village of Newtownforbes and Drumlish, as he regarded them as agricultural villages. Lastly, he told me that it is competent for his court to give a vesting order even in the case of a cash purchase.

He then wrote for me a memorandum which I give here:

\section{IRISH LAND COMISSION - AGREEMENTS FOR PURCHASE OFFICE}

\section{ESTATE OF LORD GRANARD}

Minute-1. Where sales have been refused for insufficient security, if new agreements at a satisfactory price are lodged, the sales can be carried out by vesting orders in the Land Commission.

2. Where sales are made for cash, they can be carried out by vesting order, the usual agreement orders being lodged.

3. There is no occasion to carry out these proceedings through the medium of the Land Judges' Court.

4. Special care should be paid to the preparation of agreements as to descriptions and map references, the earlier agreements having been very incorrect, and caused much delay.

M. O'B. 
Finally, Mr O'Brien sent me a list of cases which the Purchase Commission has sanctioned, but for which they cannot pay over the money, owing to some defect caused chiefly by the delay in forwarding the cases by the solicitors.

\section{THE MAP OF LADY GRANARD'S PURCHASE}

I applied, again and again, to Messrs Crozier, but with no success, for the map of the lands included in Lady Granard's purchase, which are defined by the acreage given in Mr Cochrane's report. Mr Chance also wrote for it frequently, and has also failed to get it. We applied to Mr Cochrane for it, and he answered that he had no map.

I have, however, succeeded in getting the measurements mentioned in the Cochrane report marked on an ordnance map, and certified to be correct by an expert.

I cannot conclude this postscript without telling your lordships, on the part of Fr Donnellan and myself, how greatly the work of our Clerical Commission is indebted to the zealous and effective co-operation of Canon Hoare and Canon O'Farrell. The task of negotiating with the tenants for the sale of their holdings was a difficult and delicate one for Canons Hoare and O'Farrell, seeing that the tenants were their own people or parishioners; but they brought to the work a prudence, a firmness, and an earnestness, which overcame difficulties, and secured for our commission whatever success had attended it.

We owe also our grateful acknowledgements to his lordship the bishop of Ardagh, for his fatherly welcome and for his generous hospitality during our stay in Longford.

ROBERT BROWNE,

President.

\section{CONFIDENTIAL}

\section{REPORT BY THE CLERICAL COMMISSION}

Of the particulars of their conference with the tenants on the unsold residue portion of the Granard estate. With observations on the Croziers 'Statements as to the residue of the estates (sic)' ${ }^{116}$

\section{AGHANORAN}

I. JAMES (FRANCIS) REILLY-Judicial rent, $£ 21, \mathrm{Mr}$ Barrington values at $£ 325$. Under process for non-payment of $3 \frac{1}{2}$ years' rent.

Offers $£ 275$.

Refer to Purchase Commission for Mr Roche's valuation.

II6 The number prefixed to each name corresponds with the number given in the 'Statement as to residue of estate' presented by Messrs Crozier to the trustees. 
2. JOHN COMMINSKY-Judicial rent $£ 23$. Signed an agreement sometime to purchase for $£ 390$. Land Purchase commissioners set aside case, as there was a dispute about a pass through his land. We were informed by a representative of Messrs Crozier that the Land Commission would advance $£ 350$.

Tenant complains that he has been deprived of a pass, without which he would not buy at all.

The case as to pass to be referred to mediation of the parish priest, and then the case to be remitted to the Land Purchase Commission for offer of advance.

3. JAMES (TERENCE) LEONARD—Signed agreement in ' 89 to purchase for $£^{256}$; consequently his annual rent from that time is $£^{10}$. The Crozier statements sets down the rent as $£_{1} 6$, and the arrears at $£_{5} 817 \mathrm{~s}$ $7 \mathrm{~d}$. The same statement mentions that the tenant refused to buy, and the holding is marked, 'to be sold in the Land Judges' Court'.

The tenants offered us $£ 200$, with one years' arrears.

We do not know why the case was set aside by the Land Purchase Court, or what value they set on the holding.

We recommend to remit the case to the Purchase Commission, and to abide by their valuation.

4. FRANCES LENEHAN, OR LEONARD-Signed agreements sometime to purchase for $£ 160$ - rent from that time $£ 6$ 8s od. The Crozier statement sets down rent still as $£ 9$ 10s, and arrears at $£_{63} 6$ s. It was stated that the Purchase Commission will advance only $\mathfrak{f}_{125}$. Not explained to us why Purchase Commission set aside this case, but the Crozier statements says that tenant 'refused to buy', and marks the holding as one 'to be sold in Land Judges' Court'. This tenant did not appear before us.

\section{ANNAGHMORE}

5. MICHAEL SPEARMAN-This tenant signed agreement formerly for 1140. The commissioners could not entertain it on the ground of 'under-letting'. He has his mother on the place as an 'under-tenant'. This tenants offer, in cash, $£ 120$ for the holding. We recommend this offer.

7. GEORGE DREW-Signed agreement under Ashbourne act; cannot say for how much. Crozier statements alleges tenant refused to sign under new Act, and holding marked to be sold in Land Judges' Court. Tenant in now willing to buy and offers $£ 125$. Recommended.

\section{BALLAGH}

8. Mrs E. CASEY (JAMES)-Signed agreement sometime to purchase for $£ 138$. We were informed by representative of Messrs Crozier that the Purchase Commission will advance only $£ 100$. A dispute as to title of holding is now settled. Tenant is willing to sign agreements for $£^{100}$. 
9. Representatives of MAJOR GREGORY - This holding is attached to Major Gregory's demesne; owes no arrears; present rent $£^{6} 5 \mathrm{~s}$. Tenant alleges that fair rent would be $£ 3$ 3s. Tenant offers $£ 70$ for purchase. $\mathrm{Mr}$ Barrington valued at $£ 90$. We think that the Barrington valuation to be a fair one. It is doubtful if this holding can be sold in the Land Commission Court, as it is attached to Major Gregory's demesne and forms part of it. The tenant will not make a cash purchase. In the Crozier statement of residue, this tenant is returned for $£^{11}{ }_{5} \mathrm{~s} 8 \mathrm{~d}$ arrears, though we saw his receiptds to 1st May 1893.

\section{BARRAGHMORE}

II. MICHAEL MOLLOY-had a holding at a rent of $£^{6}$. He is now in America, and has made over his holding to his sister, who offers $£ 75$ under the Land Court for it. We recommend this offer for acceptance.

\section{BARRAGHMORE}

13. JAMES HENRY-Has a holding at a rent of $£ 3$ 12s. He offers to purchase under the Land Court at $£ 37$ 10s. We understand that there will be no difficulty in getting this case through the court. We recommend the offer for acceptance.

\section{CARROWBEG AND GARROWHILL}

19. BRIDGET FARRELL-Signed agreement sometime to purchase for $£ 330$; consequently annual interest or rent about $£ 13$. In the Crozier statement the rent is set down at $£^{18}$ 15s. The tenant has two holdings one in Carrowbeg and one in Garrowhill. The case was refused by Purchase Commission, because the tenant could not agree to amalgamate both holdings. She now agrees to amalgamation, and is willing to sign agreement for $£ 300$. We recommend to accept the offer.

\section{CLOONFORE}

2I. JOHN HOPKINS is engaged in dispute with his neighbours about the bog boundary. This and similar cases are referred to the parish priest for settlement; and when boundary question is settled, all such questions to be remitted to the Purchase Commission.

24. MAY FARRELL-Rent $£_{1} 6 \mathrm{~s} 8 \mathrm{~d}$. She signed an agreement to purchase some time ago for $£^{20}$. The commissioners would not sanction it, as tenant had no visible means, not even a house on the holding. If the commissioners do not take up the case again, we should recommend to sell for $£ 15$, as there is some likelihood that she can get the money from friends in America.

26. JAMES MAGUIRE-This tenant and his neighbours of the townland of Cloonfore have been disputing about the partition of the bog. With these poor tenants the allotment of bog, or of exhausted bog-land is a matter of great importance. Without bog these holdings are almost valueless. Hence the importance of retaining the bog for equitable 
distribution amongst such tenants. Until this bog distribution is finally settled the Land Purchase Commissioners cannot take up the cases.

29. JAMES EGAN-This tenant's rental is $13 \mathrm{~s} 4 \mathrm{~d}$. He is willing to pay $£ 5$ in cash for the holding. It would seem to us that $£ 7$ would be a reasonable price, though the place is so miserable and small that it is not easy to fix the value of it. Note that this tenancy also was to be sold through the Land Judges' Court, in which case it would be practically impossible for the tenant to pay for title.

30. GREGORY OATES-Holding close to demesne; marked in Crozier statement to be sold in Land Judges' Court; don't know why. Rent $£ 3$. Offer $£^{6} 2$ 10s. Recommended.

32. PETER CASH-Rent $£^{2}$ 5s. Set down in Crozier statement as $£^{1} 12 \mathrm{~s}$. Offers $£ 40$. Offer recommended.

33. BARTLE MAHON-Rent $£ 5$ 10s. In Crozier statement, rent set down as $£ 713 \mathrm{~s}$ 2d. Holding adjoins demesne; marked in Crozier statement to be sold in Land Judges' Court. No reason for this course. Tenant offers $£ 75$. Recommended.

\section{DRUMMEEL}

34. MARY DOLAN-Yearly rent, u1s. She offered $£ 9$ for her holding, or over 16 years' purchase. She actually tendered the cash, which we were unwilling to take, as our commission was only to enquire and report. Moreover we were informed by the representative of Messrs Crozier that she should take out a title through the Land Judges' Court, which would be expensive. We regard the offer made by this poor tenant as the full value of her holding, which is, we were informed, a very miserable thing by the wayside. According to the Crozier statement this holding was to be sold through Land Judges' Court.

35. REV M. MONAHAN-His yearly rent is $£ 8$ 12s $6 \mathrm{~d}$. The landlords' portion of the taxes to be paid amounts to about 15s, which reduces the net rent to $£ 717 \mathrm{~s} 6 \mathrm{~d}$. Fr Monahan is willing to purchase for $£_{160}$, if he can buy his holding under the Land Purchase Commissioners. This is up to 20 years' purchase.

36. Representatives of P. D. LEE-No one appeared to represent this holding, nor could we get accurate information regarding it from the gentleman who attended from Mr Crozier's office. It was supposed to refer to some bog. Rent set down at $£^{1} 5 \mathrm{~s}$.

37. FEELY-We were informed by the representatives of Messrs Crozier that Feely had purchased already for $£ 30$.

38. WILLIAM DENISTON-Signed agreement to purchase in the year 1889 for $£ 1,400$. Consequently his annual interest or rent since then is $£ 56$. The Crozier statements sets down the rent as $£ 10019 \mathrm{~s}$. He paid the interest on present rent on this amount $\left(£^{1,400}\right)$ to Mr Darley till 
November 1891 , inclusive; paid nothing since then, because he was not asked for it directly or indirectly since that date.

The case was first set aside by the Land Purchase Commissioners, on the ground that he had two under-tenants. This objection is now removed, as Deniston allows the under-tenants to purchase, each his own holding, while Deniston purchases the residue. They are willing to purchase for the amount of the original agreement, $£^{1,400-}$ Deniston buying for $£^{1,170}$, and each of the under-tenants for $£^{115}$. Deniston and each of the under-tenants are willing to pay one half year's interest or rent. Deniston's arrears on present rent would amount to $£^{84}$. He is set down in the Crozier statement as in arrear for $£ 355$. They will, we presume, explain this and all similar cases.

40. DENIS FARRELI-Is dead. His representatives, viz., his two sons, John and Denis Farrell, and his son-in-law, Laurence Crowe, have been evicted from the holding. They have been admitted back as caretakers. They are disputing about bog, and until this dispute is settled, and the boundaries rectified, the case will not be received by the Land Court.

We recommend that that case be referred for settlement to the parish priest and Mr Rafferty, the bailiff on the estate.

\section{DERAWLEY}

41. ALICE AND ANNE CONNOLLY - Sisters have divided their mother's holding, the rent of which was $£ 6$ 13s. They will purchase under the Land Court for $£ 37$ 10s each. We recommend these cases for acceptance.

42. BRIDGET MULBERVEY-Has a holding at a rent of $£ 5$ 10s $10 \mathrm{~d}$ for which she offers $£^{62}$, under the Land Court. We recommend this offer for acceptance.

44. JAMES AND DANIEL McGEE, brothers-appeared before us. They are disputing about boundaries, and are not prepared to settle. We recommend that the case be referred to the parish priest.

\section{EDERCLOON}

46. THOMAS COX, JAMES DRUM-These tenants signed agreements to purchase, but case was set aside by Purchase Commission on account of a dispute between them as to boundary. Dispute now settled, and they are willing to sign agreement, each for $£^{6} 2$ 10s od. We recommend to remit case to Purchase Commission. In the Crozier statement the holdings are marked for sale in Land Judges' Court.

\section{EMBEYS}

48. REV B. O'REILLY, represented now by Rev John Briody, P. P. No appearance. To be offered for terms similar to those given to Father Monahan. 
49. DANIEL MAGUIRE-This tenant agreed formerly to purchase for $£ 80$; but owing to a dispute regarding bog with a neighbour, the commissioners could not enter into the case. The dispute is now at an end. The tenant now declines to purchase for more than $£ 50$. We suggest to accept whatever the Land Purchase Commission are prepared to pay for it, blotting out arrears.

\section{GARROWHILL}

51. ELLEN MCCORMACK-Has a holding at a rent of $£ 9$ 10s. Her son, Thomas McCormack, who is now in possession of the holding, offers to purchase it under the Land Court for $£ 150$. He must first prove his title as representative of Ellen McCormick (sic) and we recommend then that the case be referred to the Land Court.

\section{GREAGH}

56. JAMES ROGERS-Signed an agreement to purchase sometime for $£ 150$. Rent in Crozier statement $£ 13$. No arrears in Crozier's statement after tenants on this townland. The case was not sanctioned by the Land Court, for some reason or other. He will sign now only for $£^{100}$. We recommend that this case be referred to the Land Court at $\mathrm{Mr}$ Roche's valuation.

\section{KILMORE}

57. MISS HOLMES - This tenant signed an agreement some years ago to purchase for $£ 323$. The case was set aside by Land Purchase Commissioners on the ground that she had not sufficient means to enable her to pay the instalments.

Tenant is very poor. She alleges that the amount mentioned in former agreement is too much. She now offers to purchase at $£^{280}$, paying in addition $£ 6$ to wipe out arrears. The Purchase Commission willing to advance $£ 280$. We suggest to accept what the commissioners are willing to give for the holding.

58, 59. BRIDGET O'GARA-represented by PAT DONEGAN and JOHN McNAMARA-Pat Donegan signed an agreement some years since to purchase for $£^{180}$. John McNamara, his neighbour, signed at the same time an agreement to purchase for $£ 65$. The Purchase Commissioners set aside this case, owing to a dispute between the tenants (Donegan and McNamara) as to their boundary. The boundary is, we were told, now fixed. Donegan hesitates to sign for $f^{180}$, on the ground that the amount is excessive. McNamara is willing to sign for the original amount offered, $£ 65$, if he gets some bog, without which his holding is of very little value. We referred the case to Canon O'Farrell, who is to report the result of his intervention. 
6o. ARTHUR HOLMES-We were informed that this tenant's case has passed the Purchase Court, though he is set down in the Crozier statement as one whose holding is to be sold in the Land Judges' Court.

\section{LISAGERNAL, NEWTOWNFORBES}

64. MISS CASSERLEY-Signed agreement to purchase for $£ 150$. Case set aside by Land Purchase Commission on ground that the tenant was not in occupancy. Will now sign for $£^{125}$, if Land Purchase Commission advance the money. Will make lower offer, if payment is to be in cash. We recommend case to be remitted in first instance to the Purchase Commission.

\section{KILMACANNAN}

65. PETER OATES-Is willing to give $£^{20}$ in cash for holding. His rent is $£^{1}$ per annum. Offer recommended.

\section{LISAGERNAL}

66. MARY SOMERS—Rent set down in Crozier statement, $£ 6$ 8s. Case marked to be sold in Land Judges' Court; don't know why. The holding adjoins the demesne. Offers $£ 100$. Offer recommended.

69. JOHN CARLIS (ANNE)-Rent $£ 7$. Is willing to sign agreement for $£ 175$. This seems to be very large amount for purchase of such a rent.

70. BERNARD COX-Rent $£ 4$. Holding adjoins demesne. Marked in Crozier statement to be sold in Land Judges' Court; do not know why. Tenant offers $£^{62}$ 1os. Offer recommended.

71. TERENCE GUNSHINAN-Has a holding at a rent of $£ 4$ 10s, which he offers to purchase under the Land Court for $£ 50$. The court, we understand, will sanction this amount.

\section{LETTERGULLION}

72. BRYAN and JOHN REILLY-Father and son have now divided their holding, the rent of which was $£ 15$. The father retains one-third of the holding, and will purchase under the Land Court for $£ 60$, or at $\mathrm{Mr}$ Roche's valuation. The son has two-thirds of the holding, and will purchase for $£^{115}$ under the Land Court. We recommend that these two cases be referred to the Land Court.

74. ELLEN WHITNEY-Has three holdings at $£ 1216$ s per year. She offers to purchase three holdings under the Land Court for $£ 135$. The law clerk of Messrs Crozier states that there will be no difficulty in getting this case through the Land Court. We therefore recommend it for acceptance.

THOMAS AND PATRICK WHELAN-Father and son have been evicted from their holding. Their names have not been returned to us by Messrs Crozier. We recommend that the case be referred to the parish priest for settlement. 
MORTGAGE PAPERS OF ST PATRICK'S COLLEGE, MAYNOOTH, I87I-I923

62. GEORGE (JANE) McDERMOTT-Rent $£ 17$. Willing to sign agreement for $£ 275$. Offer recommended.

\section{LISBRACK, NEWTOWNFORBES}

77. THOMAS IGOE-Has four holdings (two in town and two in country).

Rent of town holdings $£ 5$ is od.

Rent of holdings in the country $£^{12} 19 \mathrm{~s} 6 \mathrm{~d}$.

Tenant offers $£ 75$ cash for town holdings, and $£ 100$ for country holdings, which latter will be bought through the Land Purchase Commission.

78. JOHN EDGEWORTH, Rose Cottage--Rent $£ 30$, the landlord being obliged to keep cottage in repair. This holding consists of a handsome cottage, with 8a 2r 7p of land. The tenant offers $£ 400$ in cash or $£ 500$ if the Land Purchase Commission will buy and advance the money.

Most Rev Dr WOODLOCK-Rent (less by half the poor rate) $£ 2315 \mathrm{~s} 5 \mathrm{~d}$. To be bought at 18 years' purchase for $£ 42817 \mathrm{~s} 6 \mathrm{~d}$. Recommended. Case not given in the Crozier statement.

\section{OGHILL}

80. ANNE HART-Signed an agreement to purchase sometime, under the Land Court, for $£ \mathbf{2 2 0}$. Her rent from that date would be about $£ 9$. Messrs Crozier set it down at $£^{12}$, and the arrears due at $£ 90$. The agreement for purchase was not sanctioned by the Court. Her husband now offers to purchase under the Land Court for $£ 150$.

We recommend that this offer be accepted.

82. ALEXANDER AND JAMES CAMPBELL, brothers-had a joint holding, now divided. Alexander has 16 acres, and offers to purchase under the Land Court for $£ 155$. He promised also to pay a year's rent. James Campbell has 9 acres, which he offers to purchase under the court for $£^{8}$. He paid Mr Nolan, who is law clerk of Messrs Crozier, one year's interest $(£ 3.6 \mathrm{~s}$.) on this sum.

We recommend these two offers for acceptance.

83. THOMAS HEANY, Junior-Is in America. His sister Margaret bought her brother's interest in this holding for $£ 240$ in cash, Messrs Crozier retaining out of this sum the entire rent due at the time on the holding.

Margaret Heany's father appeared before us and offered to purchase the holding for his daughter under the Land Court for $£^{80}$.

We recommend this offer for acceptance.

JAMES CAROLAN-Not in Crozier statement - Signed agreement to purchase for $£ 50$. The boundaries of his holding were not then settled; and hence case could not be entertained by the Land Court. The boundaries are now settled, and James Carolan is still prepared to purchase at $£ 5 \circ$, under the Land Court. 
We recommend that this offer be accepted, and that the case be referred again to the Land Court.

The tenant's name does not appear on list supplied to us by Messrs Crozier.

\section{SORAN}

84. JAMES LEE (JOHN)-Signed agreement sometime to purchase for $£ 120$; consequently annual rent or interest since then about $£ 5$. Rent set down in Crozier's statement as $£ 79$ s. $4 \mathrm{~d}$.

Alleged cause of rejection by Land Court, because tenant was in America when case came on.

The tenant now refuses to sign for $£ 120$, but offers $£_{100}$.

Refer case to Land Purchase Commission for Mr Roche's valuation.

85. JAMES ARCHBOLD—Signed agreement for $£ 87$. Paid only one instalment. Did not appear before us.

The tenant is a police constable.

Returned in Crozier's statement as owing no arrears. We have not seen his last receipt.

86. JOHN MURPHY (dead), represented by Mary Murphy-Signed agreement some time to purchase for $£ 100$ - consequent interest or rent, $£ 4$ - rental set down in the Crozier statement as $£^{8} 5$ s.

This tenant paid no rent for six or more years, though in the Crozier statement there are no arrears against him.

Case set aside by Purchase Commission on the ground of incorrect area in agreement. Matter not yet conceded.

We recommend remitting case, with correct area, to purchase commissioners.

87. MICHAEL LENNON-Reported in the Crozier statement to be dead. His representative did not appear before us. This tenant is set forth in Crozier's statement as owing no arrears. We have not seen his last receipt for rent paid.

We were informed by representative of Messrs Crozier that the Land Purchase Commission will advance $£ 75$ on this holding.

88. MICHAEL MURPHY-Signed agreement some time to purchase for $£ 290$ - paid no rent for four years, yet he is set down in the Crozier statement as having no arrears.

The tenant now refuses to sign the agreement.

It was stated to us by representative of Messrs Crozier that the Land Commission will advance $£ 250$ on this holding.

The case to be remitted to Land Commission.

89. DAN MAGUIRE, represented now by his son-Signed agreement some time to purchase for $£ 40$. The tenant who signed is now dead. The son refused to sign same agreement. 
MORTGAGE PAPERS OF ST PATRICK'S COLLEGE, MAYNOOTH, I87I-I923

This tenant has not paid rent for several years, yet he is set down in the Crozier statement as having no arrears against him.

Remit case to Land Commission for Mr Roche's valuation.

90. JAMES HUGHES-Signed agreement in ' 89 to purchase for $£ 88$ consequently annual interest or rent about $£ 3$ 10s. In the Crozier statement rent set down at $£ 516 \mathrm{~s} 6 \mathrm{~d}$.

This tenant paid interest or rent till ' 91 . Paid nothing since, not having been asked to pay.

No arrears are set against him in the Crozier statement.

He now refuses to sign an agreement to purchase.

The tenants generally in this townland of 'Soran' expressed a willingness to accept 'Roche's' valuation. Mr Roche is the value (sic) for the Land Purchase Commission.

We recommend to remit case to Land Commission, and abide by its decision.

91. JOHN LENNON-Signed agreement some time to purchase for $£^{220}$. Consequently annual rent or interest since then in $£ 816 \mathrm{~s}$.

The Crozier statement returned rent as $£ 13$ per annum.

We were informed by representative of Messrs Crozier that the Land Purchase Commission will advance $£ 200$.

Case to be remitted to Land Purchase Commission for Mr Roche's valuation.

92. JOHN HANNIGAN-Signed agreement some time to purchase for $£ 275$. Consequently annual rent or interest since then is $£^{11}$. The Crozier statement sets forth rent as $£ 17$ 9s. 8d.

The case refused by the Land Commission on ground that the tenant had no visible means of meeting instalments.

No arrears are marked in the Crozier statement against this tenant.

We recommend to refer case again to the Land Commission for $\mathrm{Mr}$ Roche's valuation.

93. PETER LEE, represented by Denis Maguire-Signed agreement some time to purchase for $£ 325$. Consequently annual rent or interest since then $£ 13$. Rent set down in Crozier statement, $£ 25$.

Complains bitterly that he has no turbary. Case rejected by Purchase Commission because of unsettled bog questions.

Tenant now offers $£ 200$ for holding without turbary, and $£ 300$ for holding with turbary.

We recommend that case be referred to parish priest for settlement of turbary, and then to Purchase Commission for their valuation.

94. Representative of PAT MAGRATH-Did not appear before us. We were of opinion from what we heard of the holding (old rent $£^{2}$ ) that the purchase value would be about $£ 25$. 


\section{ARCHIVIUM HIBERNICUM}

95. PAT (FRANCIS) QUINN—Signed agreement sometime to purchase for $£ 170$. We were informed that the Land Purchase Commission would give only $£ 150$.

We recommend that the case be remitted to Purchase Commissioners, and to abide by its valuation.

\section{AUGHNAMONA}

98. HENRY (KATE) M'GARRY - Tenant's (Kate) husband signed agreement to purchase for $£ 130$.

Husband now in America.

Present tenant declines to sign for $£ 130$.

Recommended to get her husband to convey tenancy to her, and the case to be remitted to Purchase Commission.

Tenant offers only $£ 75$.

\section{BELLAHEEHER}

IOO. BRIDGET M'GARRY-Signed agreement for $£ 58$. Not explained why the case did not pass commission.

Will now sign for $£ 50$.

Recommended to refer case to commission.

IOI. FRANCIS (by MARY SHANLEY)-Judicial rent $£ 8$ 18s. (Returned in the Crozier statement as $£ 10$ 10s.)

Tenant is a police sergeant, who is serving in a distant part of the country. His wife undertook to know from him if he will buy for cash.

Mr Barrington's valuation $£ 140$.

I02. MICHAEL (WILLIAM) SHANLEY-Signed agreement to purchase for $£^{113}$. Consequent rent since then about $£ 4$ 13s. The Crozier statement sets forth rent as $£ 6$.

The Purchase Commission would not advance $£^{113}$. The tenant now offers $£ 75$, which seems fair.

No arrears marked against him in the Crozier statement, though he did not pay for three years.

I04. BRIDGET DEVINE-Offers $£ 55$. Case to be referred to Commission for Mr Roche's valuation.

\section{CLONCOLRY}

105. MICHAEL DALY-Judicial rent is $£_{18} 10$ s. Tenant is willing to sign for only $£ 200$.

Mr Barrington valued it as $£_{2} 60$.

We recommend $£ 260$ as amount of purchase, but also to refer case to the Purchase Commission.

\section{CLOONLEGH}

I06. THOMAS SHANLEY-Has two holdings, at judicial rent of $£ 1017 \mathrm{~s}$ $6 \mathrm{~d}$, and $f_{14}$ 10s. per year. Mr Crozier sets down the annual rent of the two holdings, $£ 33$ 9s. Mr Shanley offers to purchase the two holdings 
under the Land Court, at $£ 360$, provided Mr Barrington's arrangement, re turbary, is carried out.

We recommend the acceptance of this offer.

\section{CLOONEAGH}

I08. JOHN GEELAN-Judicial rent, $£ 5$ 10s. The Crozier statement sets forth the rent as $£ 8$ 2s., and arrears $£ 25$ 6s. Barrington's valuation, $£ 86$.

Tenant agrees to sign for $£ 70$.

To be accepted or referred to Court of Purchase.

I09. THOMAS MAXWELL-Judicial rent, $£ 4$ 10s. Rent set forth in Crozier statement as $£^{6} 14 \mathrm{~s}$.

Offers $£ 56$.

To be referred to Commission for Mr Roche's valuation.

IIo. THOMAS KEENELAN-Signed agreement to purchase for $£ 155$. Do not know for certain why Purchase Commission did not pass the case, but probably because of unsettled turbary.

This tenant bitterly complains, and resents the action of the estate authorities in making a public passage through his little farm to an extensive bog. This extensive bog (over 40 acres) should belong to the Maynooth trustees; but we fear that it is about being seized by the estate, to the great injury of the tenants, and with the power of afterwards selling it to them. This case demands close investigation. The tenant charged the local estate manager (Rafferty) to his face as accountable for this proceeding.

\section{CLOONMORRIS}

II2. JOHN GANLY-Judicial rent, $£ 9$ 5s. 1d. Rent set down in Crozier statement as $£^{11} 16 \mathrm{~s}$. 6d., with arrears of $£ 84$ 10s. 6d.

Signed agreement to purchase for $£ 150$. Paid interest on rent till 1890 , but nothing since, as he was not asked for it.

Agrees to sign for $£ 150$, and gives $1 / 2$ year's arrears. We recommend to remit case to Land Purchase.

II3. Representatives of ROSE BEIRNE-James Beirne (representative) is reported to have bought for $£^{112}$.

II5. PAT HOEY, represented by John Flynn. Judicial rent, $£ 98$ s. The Crozier statement shows rent as $£ 13$ 10s.

Signed agreement to purchase for $£ 235$.

John Flynn, present representative, repeats same offer, and undertakes to establish right of tenancy.

Recommend case to be remitted to Land Purchase.

II7. JAMES FLYNN (dead), represented by Thomas Beirne-Signed agreement in ' 89 , to purchase for $£ 96$. Consequently, annual rent nearly $£ 4$. Rent set down in Crozier's Statement as $£ 5$ 10s, with arrears of $£ 18$ 9s. 9d. 
Tenant paid interest on rent till '91; but not since, as he was not asked for it.

Tenant is willing to sign again for $£ 96$, and will pay arrears, $£ 317 \mathrm{~s}$.

We recommend case to be remitted to the Purchase Commission.

\section{CLOONTURK}

122. PATRICK FITZPATRICK-Judicial rent, $£ 915$ s. Signed agreement to purchase for $£ 180$; paid one half year's rent in ' 90 .

Commission refused to advance $f_{18} 8$. Second agreement signed for $£ 150$.

He now agrees to sign for $£ 125$.

To be referred to Purchase Commission.

\section{CLOONTURK AND KNOCKMACRORY}

123. THOMAS BRADY - Has three holdings; rent of all three, $£ 39$ 2s $4 \mathrm{~d}$.

Tenant offers $£ 575$, or nearly 14 years' purchase. Arrears to be wiped out.

126. MICHAEL REYNOLDS-Holding not wholly agricultural. Did not pay rent for $1 \frac{1}{2}$ years, yet he has a clear record as to arrears in the Crozier statement.

Judicial rent for two holdings, $£ 15$ os. nd.

Tenant signed an agreement to purchase for $£^{266}$; but the Purchase Commission would advance only $£ 175$.

He consents to sign for $£ 175$.

\section{CLOONTURK}

125. WILLIAM MULLOY-Signed agreement in ' 89 to purchase for $£ 150$; paid first half year's interest or rent; paid nothing since, because he was not asked for it.

He now declines to sign for $£ 150$, but offers $£ 100$.

Recommend to remit case to Purchase Commission, or get $\mathrm{Mr}$ Roche to value.

\section{DROMARD}

128. PAT M'GLYNN and MICHAEL M'GLYNN-Signed agreement to purchase for $£ 275$. Consequently rent since then $£ 11$. The Crozier statement set down rent $£ 15$, with $£ 68$ arrears.

Case set aside by Purchase Commission because of unsettled boundary.

The boundary question now settled. Each offers $£_{100}$ to purchase.

Recommend to remit case to Purchase Commission.

129. WILLIAM M'GLYNN-Signed agreement in ' 89 to purchase for $£ 425$. Consequently annual rent since then $£ 17$. The rent set down in the Crozier statement is $£^{2} 6$ 10s, with $£^{26}$ 10s arrears. The tenant paid his interest or rent till ' 90 ; but none since, because he was not asked for it. 
MORTGAGE PAPERS OF ST PATRICK'S COLLEGE, MAYNOOTH, I87I-I923

Tenant agrees to purchase for original amount, $£ 425$.

We recommend to remit case to Purchase Commission.

\section{DRUMARD}

130. JOHN REYNOLDS, represented by his son.

Judicial rent $£^{11} 4$ s. Owes 2 years' rent. Signed agreement to purchase. Paid interest to ' 91 , not since.

Refuses to buy unless he gets the customary bog up to the town.

We think that $£ 150$ would be a reasonable amount for purchase.

Recommend case to be remitted to Purchase Commission for $\mathrm{Mr}$ Roche's Valuation.

\section{KNOCKDRINAN}

137. PATRICK (ELLEN) BEIRNE-Signed agreement in ' 89 to purchase for $£_{112}$. Consequently rent since then $£ 4$ 11s, but set down in the Crozier statement at $£ 512 \mathrm{~s} 6 \mathrm{~d}$. Paid interest on $£_{112}$ till '91; but not since, as tenant was not asked for rent.

Patrick Beirne is dead. The holding to go to his son, and the mother will get it in trust for him.

Purchase Commission has sanctioned advance of $f^{112}$. Case to be remitted to Purchase Commission.

135, 136. MICHAEL MOLLOY and B. CHANDLEY-Judicial rent $£^{8} 15$ s. Signed for $£ 175$.

Case formerly rejected by Purchase Commission, as the tenants were joint holders.

Tenants have now separated, and each is willing to buy.

Molloy offers to sign for $£ 75$; Chandley, $£ 100$.

Recommend case to be remitted to the Purchase Commission.

I38. THOMAS (ELIZA) KEALAGHER-Signed agreement to purchase for $£ 700$. Purchase Commission would sanction $£ 700$.

Kealagher dead. His heir-at-law has to make out title. He offers to sign for $£ 600$. Holding is said to be worth $£ 700$.

Refer case to Commission.

\section{MEELRAGH}

140. MRS HANLEY-Signed agreement to purchase for $£ 190$. Purchase Commission refused to grant this amount. Consequently rent since then $£^{6}$.

The Crozier statement mentions rent as $£^{10} 15 \mathrm{~s}$ with arrears of $£ 55$ 6d.

Case set aside by Purchase Commission on ground of tenant's insufficient means.

Tenant now offers to sign for $£ 125$, which seems fair. Case to be remitted to the Land Purchase Commission. 


\section{RENAGOWNA}

I4I. CATHERINE FARRELL-Signed agreement to purchase for $£^{200}$. Consequently annual interest or rent since then, $£^{12}$. The rent set down in Crozier statement, $£^{17} 15 \mathrm{~s}$. Set aside by Purchase Commission, because of contention about bog. Offers $£ 300$ now.

Offer recommended.

\section{DRUMLISH}

146. HENRY ASHE-Has a holding at a judicial rent of $£ 4$ 5s., for which he offers only $£^{20}$. We consider that the holding should be worth at least $£ 40$.

We recommend that the case should be referred to the parish priest.

148. REV THOMAS CONEFREY, P.P.-Has two holdings-one at the non-judicial rent of $£ 715 \mathrm{~s}$., and the other at the judicial rent of $£ 3$. Making allowance for half the poor rate, the net arrears due by Father Conefrey may be set down at $£ 30$.

Mr Crozier sets down the rent of Father Conefrey's two holdings at $£ 13$ 9s 6d. per annum, and the arrears due by him at $£ 48$ 9s $2 d$.

The two holdings consist of only about 4 Irish acres of land, and a few small houses. Father Conefrey offers $£ 100$ for the two holdings.

Considering that the land is very bad, and that the non-judicial rent is very high, we recommend the acceptance of this offer.

149. WILLIAM DELANY-Has a holding at a rent of $£^{1}$ 2s. He offers only $£ 5$ for the holding.

We consider it should be worth about $£_{13}$, and we cannot therefore recommend his offer for acceptance.

To be referred to the parish priest for settlement.

150, 160. JOHN REYNOLDS-Has two holdings at a rent of $£ 14$, the valuation being only $£ 716 \mathrm{~s}$. There are some good houses on those holdings, all of which Mr Reynolds built at his own expense. Arrears are due to the amount of $£_{22}$. He offers $£ 150$ in cash for the two holdings, arrears included.

We recommend this offer for acceptance.

151. JOHN KANE-Has a holding at a rent of $£^{2}$. He could not make any cash offer. He would probably purchase under the Land Court, if the court would advance the money for it.

If the case cannot be brought under the court, we recommend that it be referred to the parish priest for settlement.

152. HUGH COLLUM-Has a holding at a rent of $£$. He offers $£$ io in cash for it, and we recommend this offer for acceptance.

JAMES M'KENNA-has a holding at a rent of $£ 1$. He has no money.

We recommend that this case be referred to the Purchase Commission. 
MORTGAGE PAPERS OF ST PATRICK'S COLLEGE, MAYNOOTH, I87I-I923

153. ELLEN DOORES, represented by MICHAEL IVERS-Has a holding at a rent of $£^{2} 5 \mathrm{~s}$, for which he offers only $£ 10$.

We consider this offer too low, and that the case should be referred to the parish priest.

I54, I55. TERENCE MULLERVEY - Has two holdings, at the yearly rent of $£^{2}$ 10s. He offers $£^{22}$ 10s in cash for the two holdings.

We recommend the acceptance of this offer.

158. BERNARD KIERAN-Has a holding at a rent of $£ 5$ 10s. He offers to purchase under the Land Court at $£ 60$.

We recommend this offer for acceptance.

I59. JAMES M'NALLY-Has a holding at a rent of $£_{14}$ 10s. He offers to purchase under the Land Court at $£ 150$.

We recommend this offer for acceptance.

164, I76. JAMES M'QUADE-Has two holdings-one at $£ 19$ 12s, and the other at $£_{1}$ los per year. Mr Crozier sets down the annual rent on the two holdings at $£ 19$ 2s and $£ 1010$ s $6 \mathrm{~d}$ respectively, and the arrears due on the larger holding at $£ 20$ 9s $6 \mathrm{~d}$, and on the smaller holding (Rent $£ 1$ 10s) at $£ 30 \mathrm{Gs}$. We can scarcely believe that arrears to the amount of $£ 30 \mathrm{Gs}$ would be allowed to accumulate on an annual rent of $£^{110 s}$.

Mr M'Quade offers $£ 135$ in cash for the two holdings, including arrears.

We recommend this offer for acceptance.

165. BERNARD THOMPSON-Son of Mary Thompson, has a holding at a rent of $52 \mathrm{~s}$, for which he offers only $£ 20$.

We consider that this holding should be worth $£ 50$, and we recommend that the case be referred to the parish priest.

166. PATRICK KANE-Has one holding, the annual rent of which is $£ 4$, and the valuation of which is $£ 35 \mathrm{~s}$. He offers $£ 40$ in cash for the holding.

We recommend this offer for acceptance.

170. CATHERINE M'MANUS (representative of THOMAS M'MANUS)Has a holding at a rent of $£ 2$. She offers to pay $£ 15$ in cash, within the next six months, for the holding.

We recommend this offer for acceptance.

17I. PATRICK CLARKE-Has one holding, the rent of which is $£ 46 \mathrm{~s}$, and valuation $£ 4$. He offers only $£ 20$ for the holding.

We consider it should be worth about $£ 45$, and we cannot therefore recommend his offer for acceptance.

PATRICK M'MANUS-Has two holdings at a rent of $£ 3$. He offers $£ 15$ for the two holdings.

As this offer seems too low, and as one of the holdings belonged to an evicted tenant, we recommend that this case should be referred to the parish priest for settlement. 
173. MARGARET LARKIN-Has a holding at a rent of $£ 2$. She offers to give $£^{2} \circ$ in cash for this holding within the next three months.

We recommend this offer for acceptance.

174. JAMES M'NAMEE-Has a holding at a rent of $£ 3$. Bernard Tiernan is returned on Mr Crozier's List as the tenant on this holding. James M'Namee offers for the holding $£^{25}$ in cash, or $£^{15}$ in cash and $£_{15}$ under the Land Court, in case his holding can be purchased under the court.

We recommend this latter offer of $£ 30$ for acceptance.

179, 183, 189. ELIZA M'KENNA-Has three holdings at a rent of $£ 17$ 10s. She signed an agreement to purchase for $£ 300$. The Land Court would advance only $£ 75$. It appears that she has no means, and cannot pay rent.

This seems to us to be a case requiring special settlement.

18I. MICHAEL WHITNEY-Has a holding at the yearly rent of $£^{1} 5 \mathrm{~s}$. Mr Farrell, Longford, has seized his house for debt, and is now legally recognised as tenant; he has allowed back Mr Whitney as caretaker. Mr Farrell offers $£ 10$ in cash for the holding.

We recommend that it should be given to $\mathrm{Mr}$ Whitney for $£ 15$, if he can induce Mr Farrell to advance it for him.

182. CORNELIUS REYNOLDS-Has a holding at a rent of $£ 7$, for which he offers $£ 75$ under the Land Court.

We recommend this offer for acceptance.

\section{DRUMLISH}

184. ALICE DUNN-Has a holding at $£^{1} 5$ s per year. She seems to have very little means.

We consider that this case should be referred to the parish priest.

Miss Conlan is returned by Messrs Crozier as the tenant of this holding.

185, 186. WILLIAM GUNSHANN-Has three holdings, at $£ 5$ per year for the three. He offers $£ 35$ in cash for these holdings.

We consider he should give at least $£ 50$, and we cannot therefore recommend his offer for acceptance.

\section{NEWTOWNFORBES}

191. MARIA M'CANN-Judicial rent $£ 36$. Valuation $£ 28$ 10s. Offers to sign agreement for $£ 550$.

We recommend this as fair.

192-3-4. THOMAS (MARY) SESSMAN has three town holdings. Tenant alleges that rent of all three is $£_{11} 10$, that rent of first holding is only $£^{8}$ 10s, and the two others $£ 3$. Produces receipts to prove this statement.

The Crozier statement sets down $£^{11}$ 10s, as the rent of the first holding. 
MORTGAGE PAPERS OF ST PATRICK'S COLLEGE, MAYNOOTH, I87I-I923

Tenant offered in cash for all three holdings $£ 136$, i.e. twelve years' purchase.

We were of opinion that $£_{16} 6$ would be about the equitable valuation.

195, 220 bis. CONVENT OF MERCY-Has two holdings-one for $£^{2}$, and the convent ground for $£^{10}$; is willing to buy for fifteen years' purchase.

We were informed that it was the custom of estate to return the $£^{2}$ rent.

Offer, $£ 15$ o for convent ground recommended.

196. JOHN M'EVOY-Has only a tenement holding. Rent $£^{2}$. Is not willing to buy for cash.

199. MRS THOMPSON-Has five town holdings; rent of all five $£^{21}$ 9s 10d. Offers in cash $£ 250$; that is, thirteen years' purchase on poor law valuation, or over eleven years' purchase on present rental.

No arrears due. Offer recommended.

208, 209. POLICE BARRACKS and COURT-HOUSE-Police barracks pays $£_{19} 9 \mathrm{~s} 4 \mathrm{~d}$, annual rent, and is held on lease.

Petty sessions or court-house pays $£ 8$ rent, but landlord obliged to supply coals for fire on court days.

The rent in both cases is secure, and there seems no necessity to sell, unless the full value is realised.

It seems to us that $£ 350$ would be a reasonable valuation.

We have received offers up to $£ 200$ from Mr M'Cann.

214. Representative (C. MOONEY) of REV P. MURRAY-Rent $£ 3$. Is not disposed to buy; no arrears; pays rent regularly.

214a. 'Old Fair Green,' Newtownforbes.

Not mentioned in Crozier statement. Measures 4 acres. We are offered $£ 250$.

Recommended.

2I4 $b$. Tenements tenanted by P. CHRISTIE, P. KELLY, and M. KELLY, Newtownforbes.

Not mentioned in the Crozier statement.

Offered twenty years' purchase for these holdings.

214c. 10 Tenements, held at over $£ 70$ per annum, and payable from month to month. These are all very good houses. No arrears due.

They are not mentioned in the Crozier statement of residue.

LISAGERNAL

216. MRS. GREGG—Rent, $£ 1515$ s od.

Tenant very poor; is under eviction notice.

We asked the parish priest to look into the case. 
237. WILLIAM PRUNTY-Rent, $£ 4$ 17s. No arrears. Offers $£ 7210$, or fifteen years' purchase on gross rental.

We consider this offer satisfactory

TRUSTEES OF CONVENT, by GOODWIN-Built a house on holding; lease of holding, dating from 1881 for 99 years. Rent, $£ 5$.

This town-holding was transferred by the nuns to Patrick Goodwin.

Tenant offers $£ 50$ in cash if he gets bog as at present. Offer seems to us reasonable.

239, 40. Representative of Most REV DR KILDUFF-This the ground of the church; rent, $£^{1}$ s. This rent was regularly returned to parish priest.

\section{ST JOHNSTOWN}

247. PAT DUFFY-Signed agreement to purchase in 1889 for $£^{200}$. Paid interest or rent on this amount till 1891 . Paid nothing since, as he was not asked for it.

The rent-warner, when brought face to face with the tenant, had to admit the fact stated. Tenant added that he had to look for them to pay, even before he discontinued payment.

The Land Commission would advance only $£ 100$ on the land; but the holding is worth more on account of the buildings on it.

Tenant offers now $£ 100$ in cash, and no more.

Case referred to parish priest, and we have reason to hope for a reasonable settlement; otherwise action should be taken in this case.

248. WILLIAM M'GRATH-This holding, partly agricultural, partly nonagricultural. Signed agreement some years since to purchase for $£_{120}$. The Land Purchase Commissioners would advance only $£ 70$ on the agricultural portion. Tenant made no offer to us. Case remitted to the parish priest.

249. THOMAS DOHERTY-Signed agreement in 1889 to purchase for $£_{150}$. Paid interest on rent till 189 . Paid nothing since then, on ground that he was not asked for it.

Case refused by Land Commission; have no note why refused.

We suggest remitting case to Land Commission, and taking what they are prepared to give for holding.

If any of the holding be non-agricultural, the tenant should advance some cash in addition.

250. SARAH FOSTER-Signed agreement to purchase in ' 89 for $£ 225$. Paid interest or rent on this amount till ' 91 . Never asked for interest or rent since, and did not on this account pay since ' 91 .

The rent-warner was brought face to face with tenant, and had to admit that such was the case.

Tenant poor. The Land Purchase Commission would advance only $£ 150$, which, we presume, is the value of the holding.

This case was also remitted to the mediation of the parish priest. 
251. JAMES BRACKEN-Signed agreement in ' 89 to purchase for $£ 165$. Paid interest or rent till ' 91 . Paid nothing since, not having been asked to do so.

Purchase refused by Land Commission on ground of tenant's want of means to meet annual instalments.

Tenant not in a position to buy for cash.

Suggest remitting case to Land Commission, and taking what they offer.

252. WILLIAM QUINN-Signed agreement in 1889 to purchase for $£^{102}$. Paid interest on rent till 1891 . Paid nothing since, because he was not asked to pay.

The Land Commission would advance only $£ 70$.

We suggest remitting case to Land Commission for reconsideration, and also to parish priest, and accepting their decision.

253. ANNE PATTERSON-Signed agreement in 1889 to purchase for $£ 68$. Paid interest on rent till 1891. Paid nothing since, because she was not asked to pay.

We suggest remitting case to Land Commission, and abiding by amount they consent to advance.

Tenant very poor. In the circumstances, $£ 60$ might be enough. Tenant promises to get security for instalments.

\section{CARTRONGOLAN}

JOHN DOONS-Has a holding at 16 s per year, for which he offers $£ 10$ in cash, within four months. His name does not appear on the List of Messrs Crozier.

We recommend his offer for acceptance.

JOHN KIERNAN-Not in Crozier statement-Has one holding at a judicial rent of $£ 8$ 10s. He is at present in America. His wife offers to purchase under the Land Court for $£ 65$. The husband must make over the holding to his wife, and we recommend that the case be then referred to the Land Court.

JAMES TIERNAN (represents BRIDGET M'QUADE, deceased)—Bridget M'Quade purchased her holding under the Land Court, and James Tiernan has merely to prove his title to the holding in order that he may be recognised as tenant. The Land Court, when this is done, will place the purchase money to the credit of the trustees.

FRANCIS FURY - Has a holding at 10s per year. He seems to have very little means.

We recommend that the case be referred to the parish priest.

PATRICK REILLY-Patrick Reilly is dead. Peter Quinn, who is married to Kelly's widow, is now in possession of the holding, the rent of which is [not specified]. 
He offers to purchase at $£ 25$ under the Land Court.

We recommend this offer for acceptance.

Widow KELLY - Has a holding, the old rent of which was $£^{2}$ 8s. The rent was raised to $£ 34 \mathrm{~s}$. She now offers to purchase under the Land Court for $£ 68$, and to pay $£ 6$ arrears.

We recommend this offer for acceptance.

\section{SOLICITOR'S REPORT}

\section{MY LORDS,}

The residue of the Granard estate has not yet been realized. The Land Commission has consented to make advances upon the entire residue, including the holdings upon which they already refused to advance any sum, and the village of Drumlish. The change in their practice removes the great difficulty of selling a residue consisting of scattered holdings, to persons other than tenants.

The sale of the demesne and adjoining lands to Lady Granard has not yet been carried out. I approved of a draft contract for the sale on 19th June 1893, subject to the accurate and definite statement of the lands to be included in it. No such statement has yet reached me from Messrs Crozier. The sum of $£^{2,962}$ los od has been lodged on deposit in Mr Crozier's name and mine, on account of the Lady Granard's purchase-money of $£^{11,850}$ os od. An absolute order for the sale has been made by Mr Justice Monroe, and the Ordnance Survey officers are preparing the necessary maps.

A charge vested in Professor Hort had priority over the mortgages to your lordships. The amount due upon it, $£ 5,09618 \mathrm{~s} 8 \mathrm{~d}$, was paid out of the proceeds of the sales already effected. Professor Hart's (sic) charge included lands not the subject of your Lordships' mortgages. I therefore obtained the possession of the deeds relating to the charge, and am entitled to marshal securities against Kennedy's Island, being the lands not already covered by the college charges. Your lordships are therefore entitled to require the sale of Kennedy's Island, and the payment out of the proceeds of $£ 5,09618 \mathrm{~s} 8 \mathrm{~d}$, and interest at 4 per cent. The trustees of Lord Granard agreed to sell Kennedy's Island to the tenants; and although these proceedings are not rapid, Chancery proceedings, which are the only alternative, would be slower, more expensive, and less effective.

I regret to have to report that great delay has all along characterised the realization; but I must remind your lordships that the state of the law is such that the Land Court has no power to make advances to tenants except where the landlord is the vendor. The powers of sale which your lordships possess are therefore entirely ineffective, as there are no outside purchasers, and I can do nothing except press Messrs Crozier to use expedition.

I annex a statement showing the amounts realized, and the unsold residue. 
MORTGAGE PAPERS OF ST PATRICK'S COLLEGE, MAYNOOTH, I87I-I923

\section{PAYMENT TO TRUSTEES}

Cash

1892. June

1893. Feb. 3
$£ 320.6 .0$

$\AA^{2,960}$
Consols

$£ 30,565.15 .0$

(Afterwards invested in $23 / 4$ Consols.)

March 17

The advance of $£ 5,395$ land stock has been authorized, but the stock has not been transferred to the Bank of Ireland.

In two cases contracts have been lodged, but no advance sanctioned yet. The purchase money amounts to $£ 450$.

In five cases agreements have been signed, but not lodged yet. The purchase money amounted to $£ 485$.

The guarantee deposit stands thus:

Great Southern and Western Railway 4 per cent debentures

Great Northern Railway of Ireland

$£ 5,340.0 .0$

Guaranteed land stock

$£ 4,900.0 .0$

Cash balance

Accrued dividends (included in stock when purchased

$£ 2,930.0 .0$

$£ 1,045$.0.0

and therefore returned as capital

44.18 .3

Kennedy's Island consists of the townlands of Annaghcooleen, containing 210A[cres] 3R[oods] 37P[erches]; Clooniher, containing 369A 3R 28P; making a total acreage of $843 \mathrm{~A}_{3} \mathrm{R} 29 \mathrm{P}$ statutue, of which $268 \mathrm{~A}_{3} \mathrm{R} 11 \mathrm{P}$ is in Lord Granard's possession. The rental of the balance is $£ 20819 \mathrm{~s}$ id.

The rental of the unsold residue of the estate is $£ 1,8036 \mathrm{~s} 7 \mathrm{~d}$.

In the action of Granard $v$ Granard for the administration of the personal estate of the late earl, your lordships' claim has been admitted for $£ 6,159$ 6s $6 \mathrm{~d}$ arrears of interest. I fear a very small dividend will be paid.

I have obtained from Lord Cloncurry's solicitor possession of an original post-nuptial settlement, dated 28th January 1840 and others to Berwick and another; and an original deed of appointment by Lord Cloncurry, dated 29th September 1820, which counsel advised should be in your lordships' custody.

I have failed to obtain any trace of the five fee-farm grants, upon the security of which the Alexander loan was made. It is evident that although your Lordships gave a receipt under the college seal for these documents, they never came into the possession of the College, and the receipt was given under a misapprehension. The mortgagor's solicitors and agent were applied to for these documents. They replied that they were not in their possession, and referred to the receipt given for them by your lordships.

P. A. Chance

27th September 1893 . 
69

Hugh Clarke [Drumlish] to Dr Browne, 29 October 1893

$$
\text { MCA, } 111 / 26
$$

Most Rev[erend] D[octo]r Browne,

I beg to inform your honour I am living in a poor and distressed position for this last five years. When I took up house in Drumlish it cost me a great deal of expenses, which was over sixty pounds to buy it and put it in repairs that I could live in it. I bought it and gave all that I was worth which left me in poverty and slavery up to the present day. I was not able to support myself and my mother with potatoes and salt, owing to the small half rood which is attatshed (sic) to the house. You may read from this the poor state of poverty which I am in. I would beg to ask your honour to look in to this state of affairs. Their (sic) is only one half rood by which I am trying to support myself and my mother. She is in a very bad state not able to do anything this last five years, so that I beg to ask your honour to give it to me at ten pounds which I am striveing (sic) to make up. I hope that you will give me my request.

Yours truly,

Hugh Clarke,

Drumlish.

70

Printed notice, 13 November 1893

MCA, 111/25

We are requested by the trustees of Maynooth College to give you notice, that we will be in ......... On ....... next at 12 o'clock, to arrange finally with you for the purchase of your holding. The object of this our final visit is to come to a friendly arrangement with you on fair terms, as moderate as can be accepted by the creditor of the Granard estate. If you fail to attend on this occasion and to come to a final settlement with us, the Granard agent will be required by the Land Court to enforce immediately your payment of rent; and you shall be liable for payment of arrears.

Signed,

R. Browne, President of College

J. Hoare, V. G. \& P. P.

J. O'Farrell, P.P.

J. Donnellan, Bursar of College 
MORTGAGE PAPERS OF ST PATRICK'S COLLEGE, MAYNOOTH, I87I-I923

\section{NOTICE TO THE TENANTS ON THE GRANARD ESTATE \\ Who have not as yet purchased their Holdings}

It is considered desirable to give certain of the tenants on the Granard estate, who have not as yet purchased their holdings, this further opportunity of making up their minds whether they will now purchase, or will continue in their position as tenants.

Those who continue as tenants will, of course, have to pay their rents, and to meet the other charges for which they are legally liable.

Those tenants who wish to purchase should at once make a reasonable offer, similar to those that have been accepted in the case of the tenants who have already purchased their holdings.

It would be quite useless, and would lead only to a further loss of time, for any tenant to make over again an offer which has been already made to us, and refused as insufficient.

Our committee have already visited the estate on three occasions, so as to afford to those tenants who might wish to purchase their holdings every reasonable opportunity of arranging the terms of purchase in personal conference with us. We cannot undertake again to visit the estate. But, as we are now about to report the final result of our proceedings to the bishops who meet as trustees of Maynooth College on Tuesday, the 16 th inst., we do not wish to do so without sending you this circular.

Any reasonable proposal for purchase now made will be considered by us. But the proposal should be in our hands, addressed to 'The President, Maynooth College', not later than the morning of Monday, the 15th inst.

Signed

Robert Browne, D.D., President, Maynooth College.

Joseph Canon Hoare, V.G., P.P.

James Canon O'Farrell, P.P.

James Donnellan, Bursar, Maynooth College.

7I

Thomas Whelan [Lettergullion, Ballinamuck] to Fr Thomas Conefrey,

$$
\begin{gathered}
9 \text { December } 1893 \\
\text { MCA, } 111 / 26
\end{gathered}
$$

Very Rev[erend] Sir,

I beg to let you know that I am and always was willing to purchase my holding, but that owing to envious neighbours coveting part of my cutaway 
bog, and through personal influence turning the agent against me, and in favour of them I have not been allowed to purchase without giving up my right of this cutaway which is mapped in with my farm and for which I am under rent.

This right of course I cannot give up, but as I am willing and anxious to purchase may I request that you will have an investigation of the facts made, and you will find that any attempt to deprive me of my cutaway would be an injustice.

I am very rev[erend] sir,

Your obedient servant,

Thomas Whelan

$$
72
$$

Thomas Crozier and Son to P. A. Chance 29 December 1893

$$
\text { MCA, } 110 / 11
$$

Dear Sir,

The surveys of all the land \&c included in the purchase to Lady Granard have been completed, but we have great difficulty in the Land Commission as that court has made frequent applications to us to allot additional bog and turbary rights to the tenants who are now purchasing and in every case we have conceded to them what they require.

We have no wish to prejudice the sale of the remainder of the estate to the tenants by reason of any difficulty being raised about the bogs as we are prepared to concede any reasonable requirements that the Land Commission may make.

It would be impossible for us therefore to proceed to sell the demesne and the bogs \&c in the Land Judges Court, as, until all the sales in the Land Commission are completed, it is hard to say what the residue of the bogs consist of.

We therefore propose that the bogs \& woods should be conveyed to Lady Granard out of court after the sales have been completed, and that the demesne and other lands in hands included in Lady Granard's purchase should be conveyed to her in the usual way by the Land Judge.

We have altered the draft agreement to carry out this object and send it to you for approval.

Yours truly,

Tho[ma]s Crozier \& Son. 
MORTGAGE PAPERS OF ST PATRICK'S COLLEGE, MAYNOOTH, I87I-I923

73

Copy P. A. Chance to Dr Magrath 9 February 1894

MCA, $110 / 11$

Dear Dr Magrath,

Please inform his grace [the archbishop of Dublin] that I have received from the Land Comm[issio]n a letter informing me that in March 1891 Messrs Crozier undertook that the rights of tenant purchasers to turbary should be defined and vested in them by such deeds executed by all the necessary parties the Comm[issione]rs should consider necessary. The Comm[issio]n adds that it is reasonable to require that the outlying bogs should be preserved for the tenant purchasers \& that if these bogs, which are barely sufficient for the future wants of the purchasers, are sold to a third party, the tenants' rights will become illusory. The comm[issio]n asks whether the Trustees propose to take any action in the matter. They have also forwarded to me a copy of an application to have vesting orders executed in thirty-three cases. Messrs Crozier who make the application state in it that his grace accepted an offer made by Lady Granard to purchase such parts of the bogs as had not on the 29th Nov[embe]r 1892 been set apart for the use of the purchasing tenants. I cannot answer the comm[issione]rs' letter satisfactorily until I know whether his grace did accept as stated. On that point his grace should know that on or about the 11th June 1893 I received from Messrs Crozier a draft contract for the sale to Lady Granard. The lands to be sold to her were not specified in it and I returned it on the 14th June approved subject to the schedules (of lands) being filled in and vouched. On more than one occasion I wrote to Messrs Crozier asking that this should be done. To this they replied that the land was being surveyed by the Ordnance Dep[artmen]t and they would complete the matter when a map was prepared. At the end of Dec[embe]r the agreement was at length returned to me with a statement of lands in the schedules. This statement included more lands than Mr Cochrane's valuation, which I understand was the basis for the sale; and as a new clause was inserted in it adding an agreement by the trustees 'to convey to Lady Granard free of expense as soon as the sales to the tenants in the court of the Irish Land Comm[issio]n have been completed all the woods and such part of the bogs on the Longford \& Leitrim estates as have not been set apart for the use of the purchasing tenants'. To me it is very clear that if his grace made the agreement which Messrs Crozier allege he meant to give to Lady Granard only such bogs as are not wanted by the tenants who have purchased and the tenants who are to purchase; but Messrs Crozier contend that no provision, so far as this contract is concerned, was to be made for the tenants who have not yet completed their purchases, in ascertaining the surplus bogs which Lady Granard is to get. It is fair to 
Messrs Crozier to note they stated they are prepared to allot turbary to the purchasing tenants. The comm[issione]rs however point out that this means a mere right to cut turf and that if the ownership of the bogs is vested in Lady Granard she can give similar rights to any number of persons she chooses and thus render the tenants' rights illusory inasmuch as in their opinion all the bogs except that beside the demesne barely suffice for the future wants of the purchasers. Apparently the sale of the entire residue of the estate to the tenants depends upon this matter which therefore involves about $£_{1} 18,000$. It requires to be dealt with promptly or the cases may be dismissed; and therefore I trust his grace will afford me the necessary information. Armed with it I shall, subject to Mr Carton's advice, apply to Mr Justice Monroe for an order upon the owners to forthwith vest the bogs in trustees for the tenants and complete the sale of the residue of the estate.

I Remain,

Dear Dr Magrath,

Yours sincerely,

\section{4}

Earl of Granard's estate: report of O'Hagan and Sons, Maynooth College solicitors, and report of receiver, A. W. Percival, 27 September $1898 .{ }^{117}$

$$
\text { MCA, } 110 / 12
$$

Since Your Graces met, last October, I am glad to report that some satisfactory progress has been made towards completing the sale of the estate. In the first place, the Land Commission proceedings are concluded, with the exception of the following matters:-

A. Three tenants' proposals still pending. There are difficulties in settling these cases to whom advance is to be made, and to whom the conveyance is to be made, owing to deaths and other changes since the original proposals were signed. The cases will be dismissed, and concluded in Land Judges' proceedings, unless the difficulties are removed within a month from this.

B. Some sums amounting to about $\$ 509$ are retained in Land Commission to redeem quit rents, which are claimed, (Messrs Crozier say wrongly) by Quit Rent Office. I am urging settlement of this question.

C. Final settlement and execution of deeds defining turbary rights of tenants whose purchases were completed since Mr Commissioner O'Brien's judgment was reversed. Messrs Crozier say these deeds will

II7 There seems to be a gap in correspondence from early 1894 to 1897 . This can be partially compensated for by a very detailed schedule of costs for the period July 1894 to December 1898 in relation to proceedings for sale on the estate, dated 3 July 1899 , to be found in folder $110 / 12$. 
be finally settled by the examiner, Mr Crookshanks, immediately on his return to business, in a few days. Mr Justice Meredith declared in court last July that he would insist on the proceedings in this case in his court being wound up thoroughly without delay. We have informed Messrs Crozier that if the turbary deeds, directed in May 1897, be not settled and completed early next month we will bring the delay before Judge Meredith.

D. The guarantee deposits retained on the most recent sales have to be registered in the name of the college. I will have this done at once.

2nd. I applied to Mr Justice Ross to appoint a receiver over all the estate which had not been disposed of through the Land Commission. On the $4^{\text {th }}$ of February last he appointed Mr A. W. Percival of Minard House, Newtownforbes. I may mention that the selection of the receiver rests entirely with the judge. No name whatever was suggested to me. I annex a copy of the report sent to me by Mr Percival within the last few days. When the Land Judges Court re-opens I will obtain an order for the receiver to pay any rents in his hands to the college on account of the money due on the mortgage.

3rd. I brought Messrs Croziers' refusal to push on Land Judges' proceedings until they got a guarantee for costs before Mr Justice Ross in May last, and obtained his order that they were to proceed with despatch. In their letter of the 3 rd of August last Messrs Crozier state:-

Since the 17th May last we have been most particular in dealing with the Land Judge portion of the business as in the event of any further notices being served on us to explain delay we are quite determined that our position will be made clear.

As to what they have done. It appears that the description of the estate in the original petition for sale did not include all the lands. Since May, Messrs Crozier have presented a supplemental petition, obtained the necessary order on it, and also obtained an order for survey of all the lands remaining to be sold. This survey is being carried out at present. Immediately on its return I will push on the settlement of the rental in the court. When I succeed in getting Messrs Crozier to settle the rental, (which could be before Christmas if they wish) we will be in a position to apply to Land Commission to carry out a sale of the agricultural holdings under the 4oth section; but the best course for selling the non-agricultural holdings, where no advance of purchase money can be obtained, cannot be satisfactorily considered until the rental is settled, and Mr Percival brings in his first account. This will not be due until the $4^{\text {th }}$ February next.

Meanwhile, delay in pushing on the sale to tenants is no longer a serious loss to the college and the Rev[eren]d T[homas] Conefrey who is acquainted with some of the poorest of the tenants, has informed me he coincides with 
my opinion, that until every tenant is made to resume the payment of his rent, there is not much use in discussing terms of purchase.

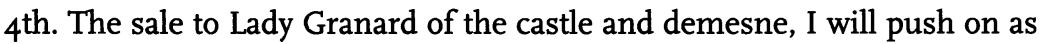
fast as I can. It is necessary to have the turbary deeds settled before this sale can be completed. When the bargain for this sale was made with Lady Granard of course the great delay that has occurred was not foreseen, and it was arranged that she should pay no occupation rent, and that the interest on four-fifths of the purchase money should only be paid in one sum at the completion of the sale. I enclose the original draft agreement in which this arrangement is approved of on behalf of your lordships by Mr Chance.

In consequence of the delay in completing the sale a large sum will be due by Lady Granard for interest on her purchase money; but I suppose she has arranged for its payment. I am anxious, however, to hurry the sale as much as possible.

O'Hagan, 3 Oct[ober] 1898

\section{Report of A. W. Percival, 28 Sept[ember] 1898}

I beg to report that I am getting this estate into working order, and I do not anticipate much further difficulty in arranging the rental, and settling the outstanding cases, before the time arrives to lodge my account in court.

The tenants have been neglected for a number of years, therefore it is not easy to arrange with them, however, when these tenants are started on a fair basis they will pay their rents.

The rental furnished to receiver, shows the total rental to be $£ 693.14 .3$

Receiver was appointed 4th February; and now, there stands to credit of account, over $£ 600$ and a number of cases still unsettled.

I attach hereto, a copy of report, lodged in court, and rulings made thereon, dated 4th May last, and all the cases then recommended for writs have been settled, except the case of Eliza Kealagher, who has entered a defence.

When the tenants hear of an early prospect of purchase, as they have heard recently, they become reluctant to pay any rent.

In the case of rep[resentative]s Auchmnty, Newtownforbes, the rental furnished to me shows $£ 91.9 .3$ due being $4^{1 / 2}$ years rent to 1st November 1897.

The last receipt, which I have seen, is dated 26th August 1895, being for 2 years rent ending 1st May 1895, thus leaving three years rent due 1st May $1898-£ 60.19 .6$-which I have received. ${ }^{118}$ 
I beg leave to state, that at the time, I received the rental, the tenants on this estate (or rather the residue of this estate) required very careful and experienced treatment, to avoid law proceedings, and publicity, and yet to collect arrears of rent.

The task would have been more difficult, had the tenants succeeded in their attempt to combine against payment of rent; however, the hardest and worse [sic] case to manage is that of Thomas Igoe, a publican residing in Newtownforbes.

When my rental and account are lodged in court, I respectfully hope, my management of the estate, shall meet with the approval of all persons interested in this matter.

The Rev[eren]d T[homas] Conefrey has advised the tenants residing in this district to settle their rents.

A. W. Percival,

Receiver,

27th September 1898 .

75

Report of A. W. Percival, 24 February 1899

MCA, $110 / 12$

.... The balance of arrears of interest due the trustees St Patrick's College Maynooth pursuant to order dated 16th November 1898 will now be paid. Owing to the peculiar circumstances of this estate for many years, the residue of the tenants had become perfectly demoralized, and the receiver had to complete his rental as best he could.

Receiver is of opinion that most of the arrears which he forgave pursuant to ruling $4^{\text {th }}$ May 1898 were irrecoverable by law. Every case was carefully treated on its own merits. The houses in Newtownforbes were delapidated (sic) and rain coming through the roofs on the occupiers. Receiver could not get men to contract to provide thatching materials and repair the houses. He had accordingly himself to undertake the entire matter, provide materials, employ workmen, and superintend the work himself. The work now done is better and more lasting work at much less cost to the estate. No less than 9 houses have been thatched and repaired for the sum of $£ 41: 8: 6$ and the occupiers satisfied so far, and the village is tidier and more comfortable. This estate is noted for its disturbed state since 1881 . Its history is given in a pamphlet published under the title of 'The Land War in Drumlish' (print sent herewith). Receiver respectfully submits that the court should grant him a substantial sum for settling the rental, superintending the aforesaid work, and coming to settlements with nearly all the tenants resulting in his collecting over 2 years' rent of estate in one year without reducing the rents even temporarily. Receiver respectfully 
suggests it was his knowledge of the tenantry and the work and his special extraordinary exertions which has avoided disturbance in settling this estate.

Receiver begs to state that his fees are inadequate to pay his travelling and other expenses, searching for old documents and correct information, and visiting every holding inspecting receipts, enquiring into means of tenants and also the details of repairing the houses in Newtownforbes.

[Note appended: 'Suggested Ruling: That receiver have permission to charge the estate $£ 100$ to compensate him for a year's constant work, settling the estate, lodging correct rental and for extra work']

$$
76
$$

Earl of Granard's estate: copy statement as to outstanding holdings on the villages of Newtownforbes and Drumlish laid before the trustees of the College of Maynooth, 24 May 1906."19

$$
\text { MCA, 110/14 }
$$

By agreement entered into between the trustees of the college of Maynooth and the countess of Granard it was agreed that inasmuch as the purchase monies resulting from the sale of the residue of the estate would be insufficient to pay the monies still due to the trustees on foot of their several incumbrances, and that inasmuch as the principal sum due had been repaid that the purchase money of the balance of the estate should be handed over to the countess of Granard on foot of her charge of $£ 5,000$ which came next in priority after the several incumbrances vested in the trustees of the college of Maynooth. Accordingly the residue of the estate as far as possible was sold and the monies (after certain payments to the trustees of the college of Maynooth which were considered as not being covered by the term of the said agreement) were paid to the countess of Granard on foot of her charge of $£ 5,000$ in all amounting to $£ 2,749: 5: 7$ leaving due to her ladyship the sum of $£ 2,250: 14: 5$ for principal and about $£ 3,100$ for interest making in all due to the countess of Granard up to date in or about the sum of £5,350:14:6.

These sales were carried out partly through the Land Commission, and partly for cash through the Land Judges, and there now remains what is commonly known as the village holdings in Newtownforbes and Drumlish together with some 7 or 8 shall (sic) holdings on other townlands. As the Land Commission would not advance the necessary purchase money for the purchase of the small residue of the estate, and as the tenants were not in a position to offer cash, the only method that could be adopted was that the sale should take place by means of the Small Dwellings Act by which

II This document has not been reproduced in full; the remainder contains names of village dwellers, rent, area, tenure and observations. 
procedure the money would be advanced by the Local Government Board. The Local Government Board refused to advance the monies on receipt of their inspector's report and pointed out that the holdings in question did not and could not satisfy the requirements of that act.

It thus becomes impossible to carry out the terms of the Agreement namely, that the holdings should be sold to the tenants. Some of the tenants, it is true, have now made offers in cash, but extremely low averaging about 8 years purchase of their holdings.

The countess of Granard's proposal now is that her ladyship should be allowed to purchase the balance of the estate for the sum that it was hoped the Local government Board would advance, namely, about $£ 1,100$, that her ladyship should give credit for this amount as against her charge and be allowed to enter into receipt of the rents and profits of the residue of the estate. The reasons for this proposal are as follows:-

1. Sales cannot take place to the tenants owing to there being no procedure available by which funds could be raised to allow the tenants to purchase.

2. Unless the proposal is accepted the estate remains in the Land Judges Court and there is the expense of receiver's accounts and other outgoings.

3. Neither the mortgagees nor the countess of Granard will derive any benefit by the estate being retained in court for the small residue of the estate.

After a perusal of the foregoing facts it is hoped that the trustees of the college of Maynooth will see their way to accede to the countess of Granard's request to purchase the residue of the estate for the sum of $£ 1,100$ or such other sum as the trustees of the college of Maynooth deem fit, her ladyship taking credit for such sum as against the balance due on foot of her charge on the estate and thus allow the petition for sale to be dismissed, the receiver discharged and the matter taken out of the Land Judges Court.

Thomas Crozier and Son,

19 L[owe]r Dominick St.

Dublin. 
77

F. M. Crozier and Son to O'Hagan and Son, 30 September 1907.

$$
\text { MCA, } 110 / 14
$$

Dear Sirs,

Our Mr F. Crozier attended at Newtownforbes yesterday, and met Mr P. McCann C.C. who had been appointed by Bishop Hoare to adjust the rents of the smallholdings that had not been sold. We send you herewith a statement showing the holdings remaining unsold, and the rents as now adjusted. The reductions in each case were extremely heavy, but, having regard to the extreme poverty of the holdings and the occupiers, it would be useless to demand a much higher rent. Besides that, special circumstances had to be taken into consideration, as the majority of the people in question were former labourers on the estate, and were then in a better position than they are now; and it is on these grounds alone that we agreed to the reductions now set out.

Yours faithfully,

Thomas Crozier \& Son 